\author{
UNIVERSIDADE DE SÃO PAULO \\ ESCOLA DE ENGENHARIA DE SÃO CARLOS \\ CENTRO DE RECURSOS HÍDRICO E ECOLOGIA APLICADA \\ PROGRAMA DE PÓS-GRADUAÇÃO EM CIÊNCIAS DA ENGENHARIA \\ AMBIENTAL
}

\title{
AVALIAÇÃO DE IMPACTOS AMBIENTAIS TRANSFRONTEIRIÇOS NA REGIÃO AMAZÔNICA - REVISÃO DE ESTUDOS DE CASO
}

ANGELA NAYIBE MORENO TORRES

São Carlos

2014 



\section{AVALIAÇÃO DE IMPACTOS AMBIENTAIS TRANSFRONTEIRIÇOS NA REGIÃO AMAZÔNICA - REVISÃO DE ESTUDOS DE CASO}

Dissertação apresentada à Escola de Engenharia de São Carlos, Universidade de São Paulo, para obtenção do titulo de Mestre em Ciências da Engenharia Ambiental.

Área de concentração: Ciências da Engenharia Ambiental

Orientador: Prof. Dr. Marcelo Montaño 
AUTORIZO A REPRODUÇÃO TOTAL OU PARCIAL DESTE TRABALHO, POR QUALQUER MEIO CONVENCIONAL OU ELETRÔNICO, PARA FINS DE ESTUDO E PESQUISA, DESDE QUE CITADA A FONTE.

Moreno-Torres, Angela Nayibe

Avaliação de impactos ambientais transfronteiriços na região Amazônica: revisão de estudos de caso. Angela Nayibe Moreno-Torres; orientador Marcelo Montaño. São Carlos, 2014.

Dissertação (Mestrado) - Programa de Pós-Graduação em Ciências da Engenharia Ambiental e Área de Concentração em Ciências da Engenharia Ambiental -Escola de Engenharia de São Carlos da Universidade de São Paulo, 2014.

1. Avaliação de Impacto Ambiental Transfronteiriça. - 2. Amazônia. . 3. Instrumentos de política ambiental. 4. IIRSA. I. Título. 


\section{FOLHA DE JULGAMENTO}

Candidata: Engenheira ANGELA NAYIBE MORENO TORRES.

Título da dissertação: "Avaliação de impactos ambientais transfronteiriços na região Amazônica - revisão de estudos de caso".

Data da defesa: 11/08/2014

\section{Comissão Julgadora:}

Prof. Dr. Aldo Roberto Ometto (Orientador designado)

(Escola de Engenharia de São Carlos/EESC)

Prof. Titular Marcelo Pereira de Souza

(Faculdade de Filosofia, Ciências e Letras de Ribeirão Preto/FFCLRP-USP)

Prof. Dr. André Luiz Oliveira

(Faculdade de Tecnologia de São Paulo/FATEC-Taquaritinga)

\section{Resultado:}

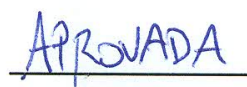

Coordenador do Programa de Pós-Graduação em Ciências da Engenharia Ambiental:

Prof. Dr. Frederico Fabio Mauad

Presidente da Comissão de Pós-Graduação:

Prof. Associado Paulo César Lima Segantine 

A mis padres Mercedes y Miguel Angel por su amor, apoyo constante, dedicación y entrega.

A mi Esposo Edicson por su invaluable amor, apoyo, sus maravillosos consejos, paciencia, ayuda y por alegrar mis días en los momentos dificiles.

A mi hijo por llenar mi vida de emociones y por alegrar mis días con su maravillosa sonrisa. 



\section{AGRADECIMENTO}

A Jeová Deus pela vida, às oportunidades e pessoas que fizeram parte destes anos de pesquisa e que contribuíram para meu crescimento pessoal e profissional.

Ao Professor Marcelo Montaño, pela orientação, ajuda, paciência, compreensão, ânimo, apoio, confiança e incentivo durante o mestrado.

À minha família por seu amor e apoio incondicional, especialmente a meus pais e meu irmão, sempre amorosos e confiantes, e meu marido por seus conselhos, apoio, ajuda, paciência e compreensão.

A meus grandes amigos da Pós Lilian, Tiago e Renata, sempre amáveis e dispostos a ajudar. Agradeço imensamente sua amizade, seus ensinamentos, risadas, sua guia no mundo brasileiro; fizeram meus dias em seu maravilhoso país mais alegres e divertidos.

A minhas irmãs colombianas Carolina, Nini e Yovana pelos momentos compartilhados, as ajudas e as saudades compartilhadas.

A todos os amigos da pós-graduação, pela amizade, o compartilhamento de experiências, os momentos de discussão que enriqueceram o aprendizado e facilitaram o caminho. Também pelos momentos de distração e diversão que me ajudaram a conhecer sua maravilhosa cultura e tornaram São Carlos mais amável e divertida.

Aos funcionários da EESC, SHS, CCEAMA e PPG-SEA, em especial à Rose, ao Zé e ao Nelson, pela disposição de ajudar.

A meus vizinhos Galia e Don Julio, por sua ajuda incondicional e pelo fornecimento da internet; a Rosa, Rogelio e Karen, por sua amabilidade e ajuda.

A Dri e sua família, por me oferecer o calor de um lar.

A Silvia e sua família, por sua amizade, amabilidade e valiosos ensinamentos.

Às professoras da CEMEI José Marrara, por cuidar tão bem de meu filho e me dar a tranquilidade para concluir meu mestrado.

A CNPq - Conselho Nacional de Desenvolvimento Cientifico e Tecnológico, pelo apoio financeiro durante o mestrado. 



\section{RESUMO}

MORENO TORRES, A.N. Avaliação de impactos ambientais transfronteiriços na região Amazônica: revisão de estudos de caso. 2014. 147f. Dissertação (Mestrado) Escola de Engenharia de São Carlos, Universidade de São Paulo, São Calos, 2014.

Processos acelerados de globalização induzem a exploração intensiva de recursos naturais em grande escala e a construção de megaprojetos que muitas vezes transpassam as fronteiras dos países. Neste contexto, a Avaliação de Impacto Ambiental Transfronteiriça (AIA-T) se converte em uma ferramenta essencial da gestão ambiental, pois tem o potencial de apoiar a tomada de decisões que podem afetar mais de um país e assim contribuir para evitar conflitos internacionais. Contudo, a implementação desta ferramenta ainda encontra muitos desafios, por tratar de temas delicados e complexos como as relações internacionais ou a soberania dos estados. No contexto mundial, apenas a União Europeia apresenta um marco normativo claro e bem estabelecido para aplicação da AIA-T de projetos, restando às demais regiões um longo caminho a ser percorrido. A América do Sul passa atualmente por um intenso processo de integração física baseado em um amplo programa de investimentos denominado "Iniciativa para a Integração da Infraestrutura Regional Sul-Americana" (IIRSA), que vem promovendo alterações ambientais significativas em toda a região, sobretudo no âmbito dos países amazônicos, sem contar com um arcabouço institucional que assegure a avaliação dos impactos transfronteiriços e a sua incorporação aos procedimentos de aprovação e implantação dos projetos associados. Sendo assim, a presente pesquisa de Mestrado visou investigar a existência de marcos institucionais e metodológicos que pudessem fornecer suporte para a aplicação da AIA-T nos países amazônicos e avaliar sua proximidade com os princípios e boas práticas desta ferramenta em nível mundial. Através de revisão bibliográfica, documental e estudos de caso, os resultados encontrados indicam que a AIA-T deve integrar os procedimentos de tomada de decisão que envolvem os países amazônicos, de modo a assegurar o cumprimento dos compromissos internacionais já assumidos em torno da proteção do ecossistema amazônico e o gerenciamento adequado dos impactos ambientais transfronteiriços.

Palavras-chaves: Avaliação de Impacto Ambiental Transfronteiriça. Amazônia. Instrumentos de Política Ambiental. IIRSA 


\section{RESUMEN}

MORENO TORRES, A.N. Evaluación de impactos ambientales transfronterizos en la región Amazónica: revisión de estúdios de caso. 2014. 147f. Disertación (Maestria) - Escola de Engenharia de São Carlos, Universidade de São Paulo, São Carlos, 2014.

Procesos acelerados de globalización inducen la explotación intensiva de recursos naturales en gran escala y la construcción de megaproyectos que muchas veces transpasan las fronteras de los países. En este contexto la Evaluación de Impacto Ambiental Transfronteriza (EIA - T) se convierte en una herramienta esencial de la gestión ambiental, apoyando la toma de decisiones que pueden afectar más de un país y así contribuye para evitar conflictos internacionales. Sin embargo, la implementación de esta herramienta aún tiene muchos desafios, por tratar temas delicados y complejos como las relaciones internacionales o la soberania de los estados. En el contexto mundial, solo la Unión Europea presenta un marco normativo claro y bien establecido para la aplicación de la EIA - T de proyectos. América del Sur pasa actualmente por un intenso proceso de integración fisica basado en un amplio programa de inversión denominado "Iniciativa para la Integración de la Infraestructura Regional SurAmericana" (IIRSA), que viene promoviendo alteraciones ambientales significativas en toda la region, sobretodo en el ambito de los países amazónicos, sin contar con una estructura institucional que asegure la evaluación de los impactos transfronterizos y su incorporación a los procedimientos de aprobación e implantación de los proyectos asociados. De esta manera, la presente investigación de maestria se propuso indagar la existencia de marcos institucionales y metodológicos que pudieran brindar soporte para la aplicación de la EIA - T en los países amazónicos y evaluar su proximidad con los principios de buenas prácticas de esta herramienta a nivel mundial. A través de revisión bibliografica, documental y estudios de caso los resultados encontrados indican que la EIA - T debe integrar los procedimientos de toma de decisiones que involucren a los países amazónicos, a modo de asegurar el cumplimiento de los compromisos internacionales asumidos en torno a la protección del ecosistema amazonico y la gestión adecuada de los impactos ambientales transfronterizos.

Palabras Claves: Evaluación de Impacto Ambiental Transfronterizo. Amazónia. Instrumentos de Política Ambiental. IIRSA. 


\begin{abstract}
MORENO TORRES, A.N. Transboundary environmental impact assessment in the Amazon basin: study case review. 2014. 147f. Dissertation (Master) - Escola de Engenharia de São Carlos, Universidade de São Paulo, São Calos, 2014.

Intensive natural resources exploitation has been accelerated at large scale by globalization processes in the last years, and its impacts might overstep political boundaries. In this scenario, the transboundary environmental impact assessment (hereafter TEIA) has become an integrated approach and essential tool for international environmental management, supporting decision taking processes with the potential to prevent cross border conflicts. Nonetheless, the implementation is still challenging due to the political and social complexity of international relationships and sovereignty of the countries involved. Hitherto just the European Union has been consolidated a clear normative framework in the implementation of TEIA. Conversely in South America this framework is not clear, due to the lack of institutional structure to set up an appropriate environmental assessment scheme, despite that nowadays several megaprojects have been established under the denominated "Iniciativa para la Integración de la Infraestructura Regional Sur-Americana" (IIRSA) - the South-American regional integrative infrastructure initiative- and serious pervasive effects associated in the environment have been recorded, being more notorious in the Amazon region, due to the inherent vulnerability of this biome. In this context, the present master dissertation discussed from a comprehensive literature and policies review and study cases, the institutional and methodological framework as the normative base of the TEIA, as well as to assess good practices for environmental impact assessment of development projects in countries within the Amazon biome. In overall TEIA must integrate the decision taking procedures of countries with influence of the Amazon biome in order to guarantee fulfil previously undertaken international agreements that protect the Amazon ecosystem, and the suitable management of environmental impacts at frontiers, and consequently to prevent future scenarios of international dispute.
\end{abstract}

Keywords: Transboundary Environmental Impact Assessment. Amazon. Environmental Policy Instruments. IIRSA. 


\section{LISTA DE TABELAS}

Tabela 1- Palavras Chaves usadas na revisão de literatura ............................................ 20

Tabela 2 - Características da Avaliação de Impacto Ambiental Transfronteiriça e suas

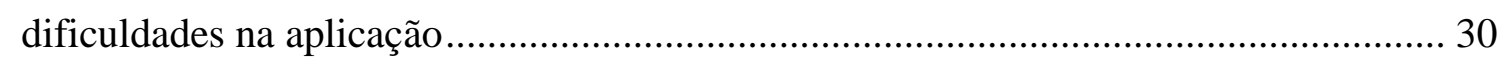

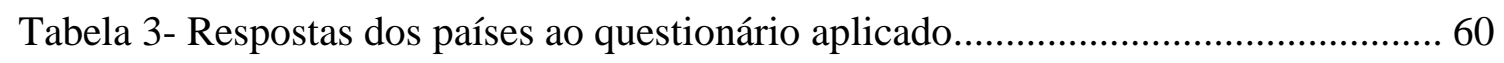

Tabela 4 - Janela para o avanço da AIA - T no âmbito sub-regional............................ 62

Tabela 5 - Análise dos estudos de caso em termos de conformidade com os princípios e

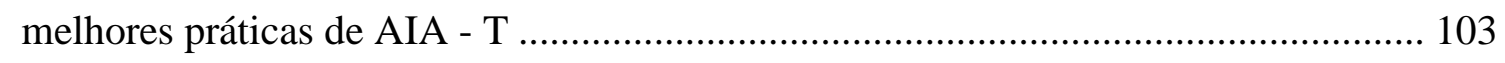




\section{LISTA DE FIGURAS}

Figura 1 - Conformação da bacia amazônica ................................................................. 17

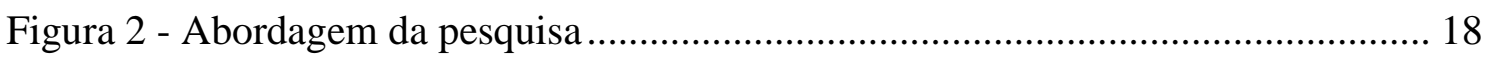

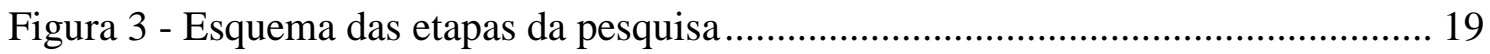

Figura 4 - Eixos de Integração e Desenvolvimento (EID) - IIRSA................................ 43

Figura 5 - Esquema processo geral AIA - T da convenção de ESPOO........................ 51

Figura 6 - linha de gás Nord Stream no mar Báltico .................................................. 53

Figura 7 - Bacia Hidrográfica do Rio Madeira........................................................... 75

Figura 8 - Localização das hidrelétricas que formam o Complexo do rio Madeira ....... 76

Figura 9 - Representação gráfica da Rodovia Interoceânica. ....................................... 83

Figura 10 - Rodovia Interoceânica no Peru.................................................................... 84

Figura 11 - Sínteses de Fases e componentes da EASE - IIRSA................................. 89

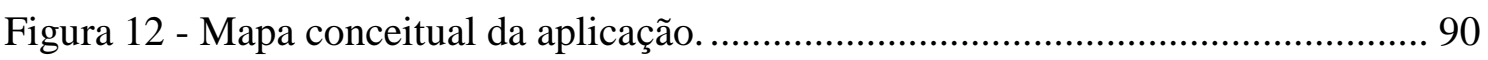

Figura 13 - Cenários considerados na aplicação da EASE.......................................... 92

Figura 14 - Eixo Andino - Grupo 6 de projetos- Conexão Colômbia - Equador II. ..... 93

Figura 15 - Eixo Sul - Grupo 2 de projetos - Circuito Turístico binacional zona dos

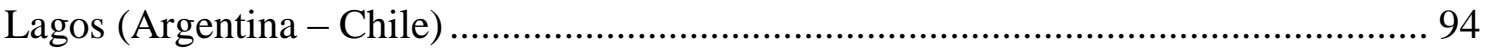

Figura 16 - Localização do projeto de transporte multimodal no sistema lagoa Merín -

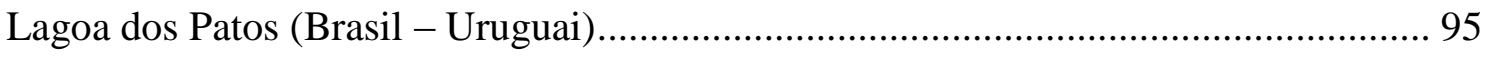

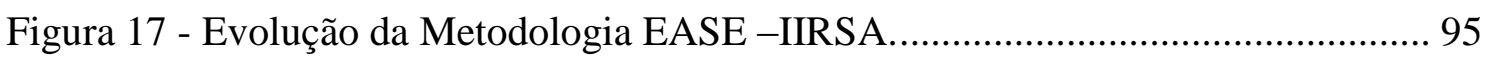

Figura 18 - Comparação princípios de AIA - T com Marco de Referencia vs Países Amazônicos. 109 


\section{LISTA DE ABRAVIATURAS E SIGLAS}

AAE

AIA

AIA-T

BID

CAF

CAN

CEBAF

COSIPLAN

EASE

EIA

EID

FONPLATA

IAIA

IBAMA

IIRSA

MEAs

MERCOSUL

NEPA

ONG

OTCA

PAC

PSI

RIMA

UNASUL

UNECE
Avaliação Ambiental Estratégica

Avaliação de Impacto Ambiental

Avaliação de Impacto Ambiental Transfronteiriça

Banco Interamericano de Desenvolvimento

Corporação Andina de Fomento

Comunidad Andina de Naciones (Comunidade Andina de

Nações)

Centro Binacional de atenção em fronteira

Consejo Suramericano de Infraestructura y Planeamiento

(Conselho Sul-americano de Infraestrutura e planejamento)

Evaluación Ambiental y Social con Enfoque Estratégico

(Avaliação de Impacto Ambiental e Social com Enfoque

Estratégico)

Estudo de Impacto Ambiental

Eixos de Integração e Desenvolvimento

Fundo Financeiro para o Desenvolvimento de Bacia do Prata.

International Association for Impact Assessment (Associação Internacional de Avaliação de Impacto)

Instituto Brasileiro do Meio Ambiente e dos Recursos Naturais

Renováveis

Iniciativa para a Integração da Infraestrutura Regional Sul-

Americana

Multilateral Environmental Agreements (Acordos Ambientais

Multilaterais)

Mercado Comum do Sul

National Environmental Policy Act (Lei de Política Nacional do

Meio Ambiente)

Organização Não Governamental

Organização do Tratado de Cooperação Amazônica

Programa de Aceleração do Crescimento

Processos Setoriais de Integração

Relatório de Impacto Ambiental

União das Nações Sul-Americanas

United Nations Economic Commission for Europe (Comissão

Econômica das Nações Unidas para a Europa) 


\section{SUMÁRIO}

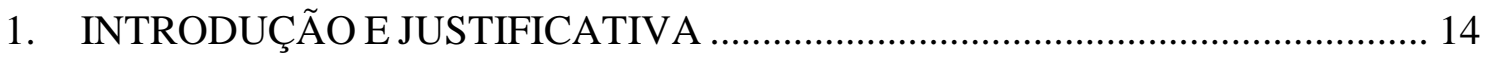

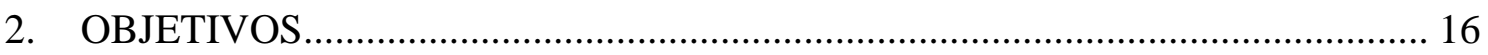

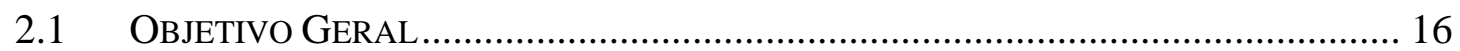

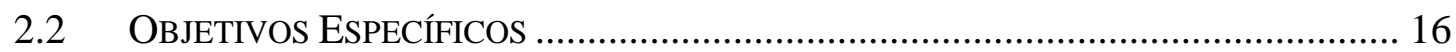

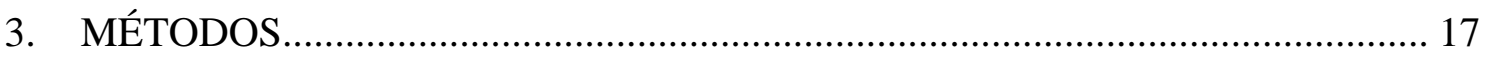

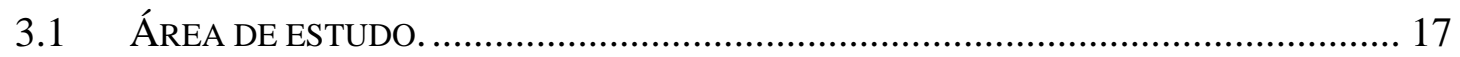

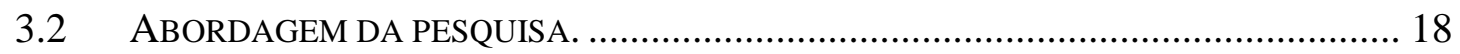

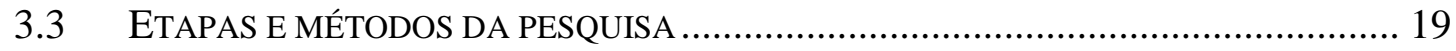

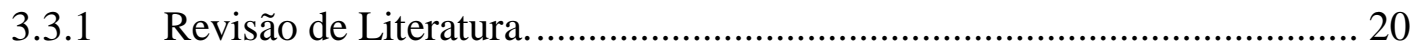

3.3.2 Escolha e descrição do marco de referência (União Europeia)................ 21

3.3.3 Revisão, análise e descrição do marco normativo e institucional dos assuntos ambientais transfronteiriços no contexto dos países amazônicos............. 21

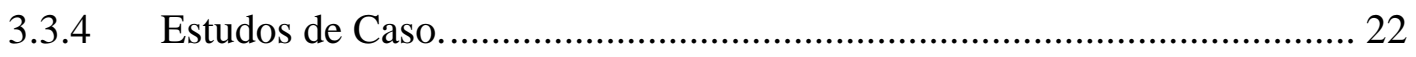

3.3.5 Análise da conformidade com os princípios da AIA-T em nível mundial23

3.3.6 Comparação do marco de referência com os países amazônicos ............. 23

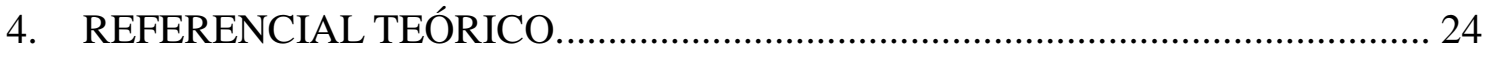

4.1 Avaliação de Impacto Ambiental e AvaliaÇão Ambiental EstratéGica

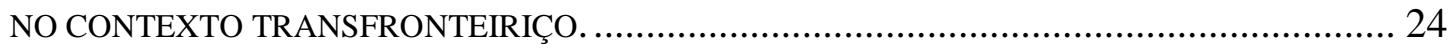

4.2 AVALIAÇÃO AMBIENTAL TRANSFRONTEIRIÇA .................................................. 27

4.3 Avaliação Ambiental TransfronteiriçA no ConteXto Mundial ......... 33

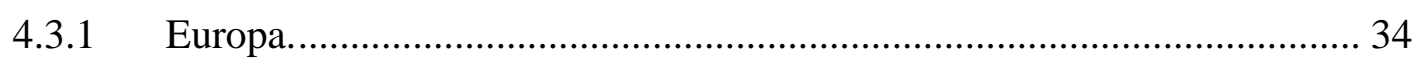

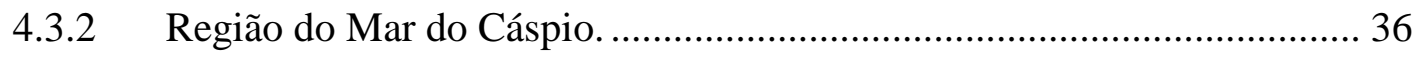

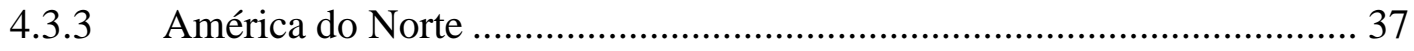

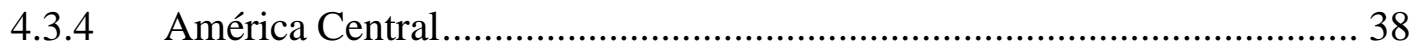

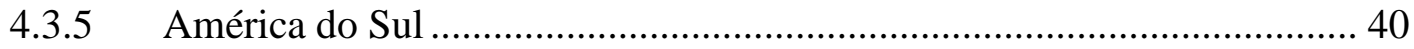

4.4 Avaliação Ambiental Transfronteiriça, CASo Europeu........................ 44

4.4.1 Aplicação da convenção de Espoo ........................................................ 52

5. AVALIAÇÃO AMBIENTAL TRANSFRONTEIRIÇA NO CONTEXTO

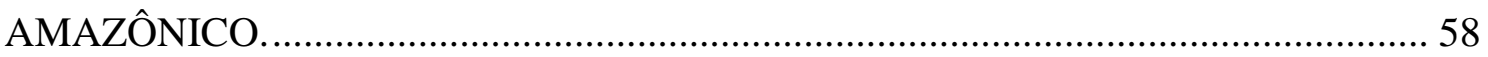


6. APLICAÇÃO DA AIA - T NO CONTEXTO AMAZÔNICO. ESTUDOS DE CASO.

6.1 COMPLEXO HIDRELÉTRICO DO RIO MADEIRA................................................... 74

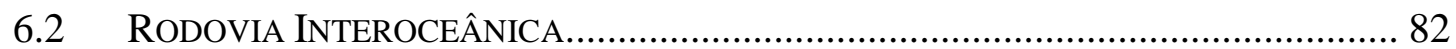

6.3 Avaliação Ambiental E Social COM FOCO ESTRAtéGico DA IIRSA. (EvAluACiÓn AMBIENTAL Y SOCIAL CON ENFOQUE ESTRATÉGICO - EASE)............... 86

6.3.1 Grupo 6 do Eixo Andino - Conexão Colômbia - Equador II .................. 92

6.3.2 Grupo 2 do Eixo Sul - Circuito Turístico Binacional Zona dos Lagos (Argentina-Chile) 93

6.3.3 Projeto de Transporte Multimodal no Sistema lagoa Merín - Lagoa dos Patos (Brasil - Uruguai) 94

7. ANÁLISE DA CONFORMIDADE COM OS PRINCÍPIOS DE AIA - T AO NÍVEL MUNDIAL. 102

8. MARCO DE REFERÊNCIA VS. PAÍSES AMAZÔNICOS …............................. 108

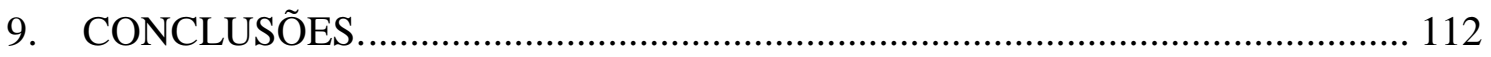

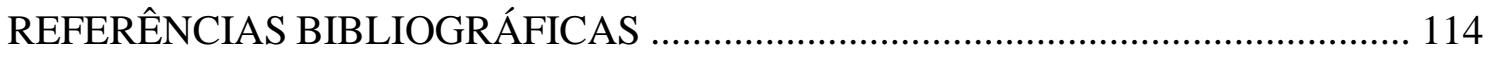

APÊNDICE A - QUESTIONÁRIOS APLICADOS................................................ 128

APÊNDICE B - LISTADO DOS ESCRITÓRIOS AOS QUE FOI ENVIADO. .............. 130

ANEXO A - NORMATIVAS REFERENTES AOS ASSUNTOS AMBIENTAIS NO ÂMBITO INTERNACIONAL NOS PAÍSES AMAZÔNICO................................... 132

ANEXO B - RESPOSTAS AOS QUESTIONÁRIOS ................................................ 150 


\section{INTRODUÇÃO E JUSTIFICATIVA}

O inicio do século XXI está marcado por processos acelerados de globalização em todos os âmbitos, onde, destacam-se a revolução das comunicações, a inter-relação das sociedades e culturas, e a geração de uma nova ordem econômica. Estas mudanças vêm causando profundas transformações nos países, levando à conformação de blocos econômicos, com procedimentos e regulamentações uniformizados e simplificados, tanto em nível nacional quanto internacional, que permitam melhorar a competitividade e a segurança jurídica, além de incentivar o desenvolvimento da infraestrutura regional para atender às demandas comerciais (BALVIN; PATRON, 2006; RHI-SAUSI; COLETTI, 2003).

Esta situação redimensiona os impactos sobre os recursos naturais e sobre o ambiente como um todo. A exploração dos recursos naturais deixa de ser de interesse exclusivo nacional para ser de interesse regional, as demandas do mercado levam à construção de megaprojetos que ultrapassam as fronteiras dos países, e os interesses econômicos e políticos incentivam a aceleração e flexibilização dos processos de tomada de decisão.

Esta tendência onde os limites nacionais perdem importância ante os impactos ambientais em áreas transfronteiriças requer o desenvolvimento de padrões internacionais da avaliação de impacto ambiental, de modo a superar as potenciais limitações causadas por diferenças na estrutura jurídica e procedimental que rege a aplicação da AIA nos países envolvidos (PURNAMA, 2004).

A experiência com a Avaliação de Impacto Ambiental Transfronteiriça (AIAT) tem-se incrementado desde os primeiros fóruns globais sobre meio ambiente, que deixaram evidente que as medidas de proteção ambiental não poderiam ficar restritas aos limites territoriais de cada país (SCHRAGE; BONVOISIN, 2008). Ainda assim, no contexto internacional, são poucas as iniciativas que asseguram que os efeitos ambientais transfronteiriços sejam de fato considerados nos processos de tomada de decisão. A AIA-T é um instrumento de política ambiental que tem um uso amplo e bem estruturado no que diz respeito a projetos junto ao bloco de países da União Europeia, e ainda há um longo caminho para que sua aplicação sistemática seja verificada nos demais blocos de países (SCHRAGE; BONVOISIN, 2008).

$\mathrm{Na}$ América do Sul, por exemplo, verificam-se diferentes iniciativas de formação de blocos econômicos entre os doze países que a constituem. No âmbito da 
União das Nações Sul-americanas (UNASUL), encontra-se em andamento um processo de integração física ao nível regional por meio da "Iniciativa para a Integração da Infraestrutura Regional Sul-Americana" (IIRSA), que congrega a maior parte dos projetos de integração propostos pelos países Sul-Americanos. No entanto, não há um marco claro e estruturado para o gerenciamento conjunto dos efeitos ambientais transfronteiriços, o que aumenta o risco de conflitos entre os países do bloco, uma vez que boa parte dos grandes projetos de desenvolvimento (inclusive os projetos implementados fora do âmbito do IIRSA) localizam-se em zonas de fronteira ou em bacias hidrográficas compartilhadas.

Em relação aos países que integram a bacia amazônica, uma das regiões mais afetadas pelos projetos de integração do continente sul-americano, a situação descrita tem contribuído para a ocorrência de impactos ambientais e sociais importantes, com possibilidade de afetar as relações diplomáticas entre países vizinhos. Sendo assim, considera-se importante conhecer a dinâmica institucional que orienta a inserção de aspectos transfronteiriços na Avaliação de Impacto Ambiental nos países sulamericanos, de modo que se tenham condições de refletir sobre a sua prática neste contexto. 


\section{OBJETIVOS}

\subsection{Objetivo Geral}

Descrever as características institucionais e metodológicas da Avaliação de Impacto Ambiental Transfronteiriça em países da região Amazônica e avaliar sua conformidade com os princípios e as boas práticas da AIA-T em nível mundial.

\subsection{Objetivos Específicos}

- Identificar os elementos institucionais que orientam a avaliação dos impactos ambientais transfronteiriços adotados nos oito países amazônicos, e posterior comparação com os principais elementos institucionais mundiais.

- Analisar os métodos de avaliação de impactos ambientais transfronteiriços, adotados pelos órgãos ambientais dos países da região Amazônica e das instituições internacionais sul-americanas, comparando com o cenário de boas práticas internacionais.

- Avaliar a conformidade do quadro institucional e metodológico dos casos selecionados com os princípios e as melhores práticas da Avaliação de Impacto Ambiental Transfronteiriça em nível mundial. 


\section{MÉTODOS}

\section{1 Área de estudo.}

A Amazônia é uma região sul-americana compartilhada pelos países da Bolívia, Brasil, Colômbia, Equador, Guiana, Peru, Suriname e Venezuela. Caracterizada por riquezas, contrastes naturais e culturais, é também drenada pelo Rio Amazonas. Trata-se da bacia hidrográfica mais extensa em todo o mundo, com mais de 1000 tributários, seus recursos hídricos têm um alto valor no equilíbrio hídrico global e continental. Além disso, apresenta altos índices de biodiversidade, endemismos e uma importante diversidade cultural, com 420 povos indígenas distintos, 86 línguas e 650 dialetos (OTCA, 1994; PNUMA et al., 2009).

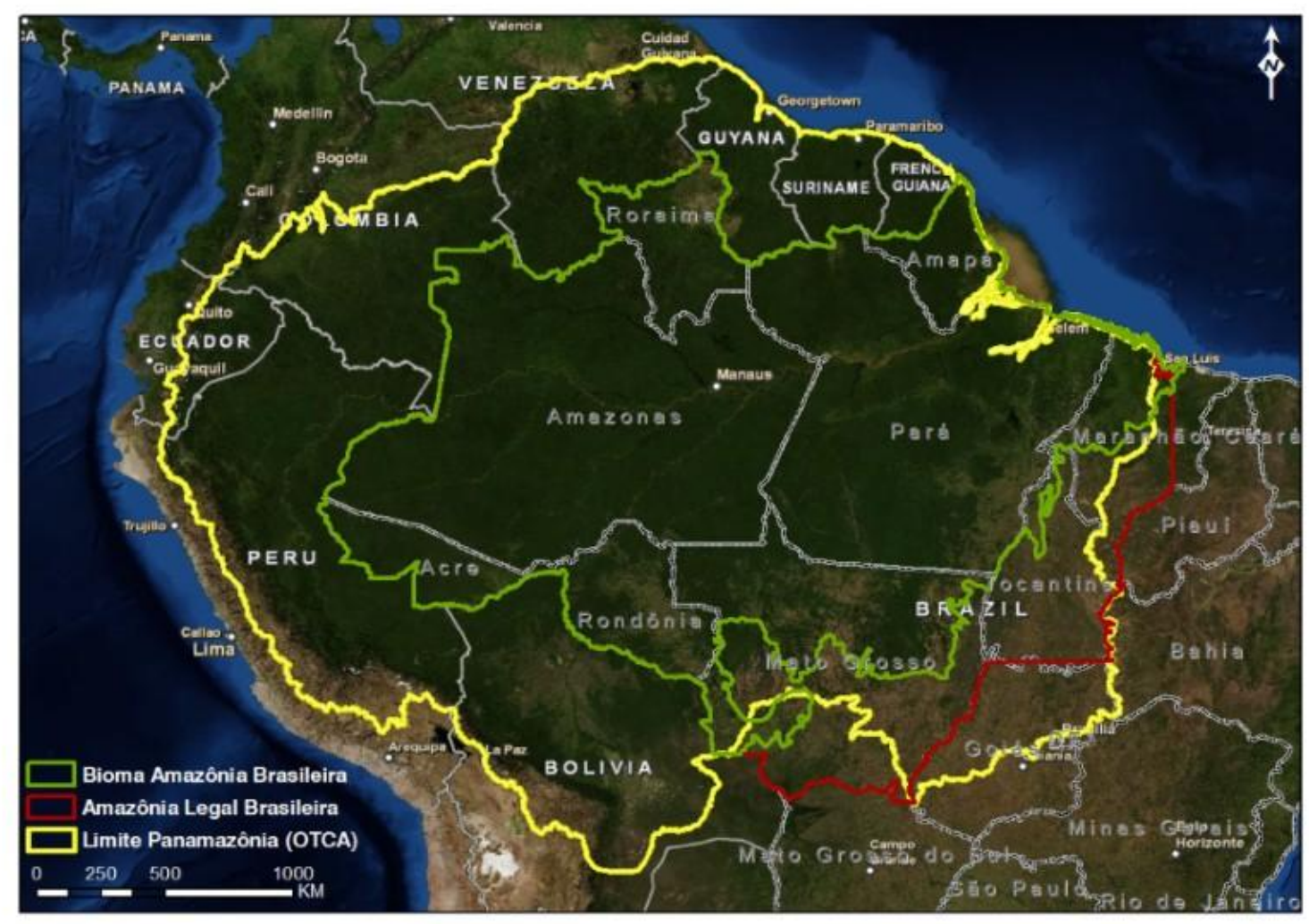

Figura 1 - Conformação da bacia amazônica

Fonte. (GREENPEACE, 2010)

A riqueza da Amazônia não só é baseada na oferta de bens tangíveis, mas também está sustentada no funcionamento de seus variados sistemas, tanto ecológicos quanto socioculturais, os quais brindam um conjunto de serviços ecossistêmicos. 
Contudo, a dinâmica econômico-produtiva em resposta à demanda dos mercados internacionais gera uma pressão para a exploração intensiva dos recursos naturais, como a produção madeireira, mineração, produção de castanha, hidrocarbonetos, a expansão agrícola e de gado, gerando um modelo de produção que não considera critérios de aproveitamento sustentável. Tudo isso somado à consequente perda de bens e serviços ecossistêmicos e aos megaprojetos, como os da IIRSA ou programas de desenvolvimento nacionais como o Programa de Aceleração do Crescimento - PAC, no caso do Brasil, os quais estão gerando alterações em um ritmo acelerado, modificando profundamente o ecossistema e reduzindo consideravelmente o bem-estar humano (PNUMA et al., 2009).

Os grandes desenvolvimentos da região, assim como o crescente interesse na exploração de seus recursos naturais e a falta de informação referente ao gerenciamento dos impactos ambientais transfronteiriços nesta sensível região, levaram a sua escolha como foco desta pesquisa.

\subsection{Abordagem da pesquisa.}

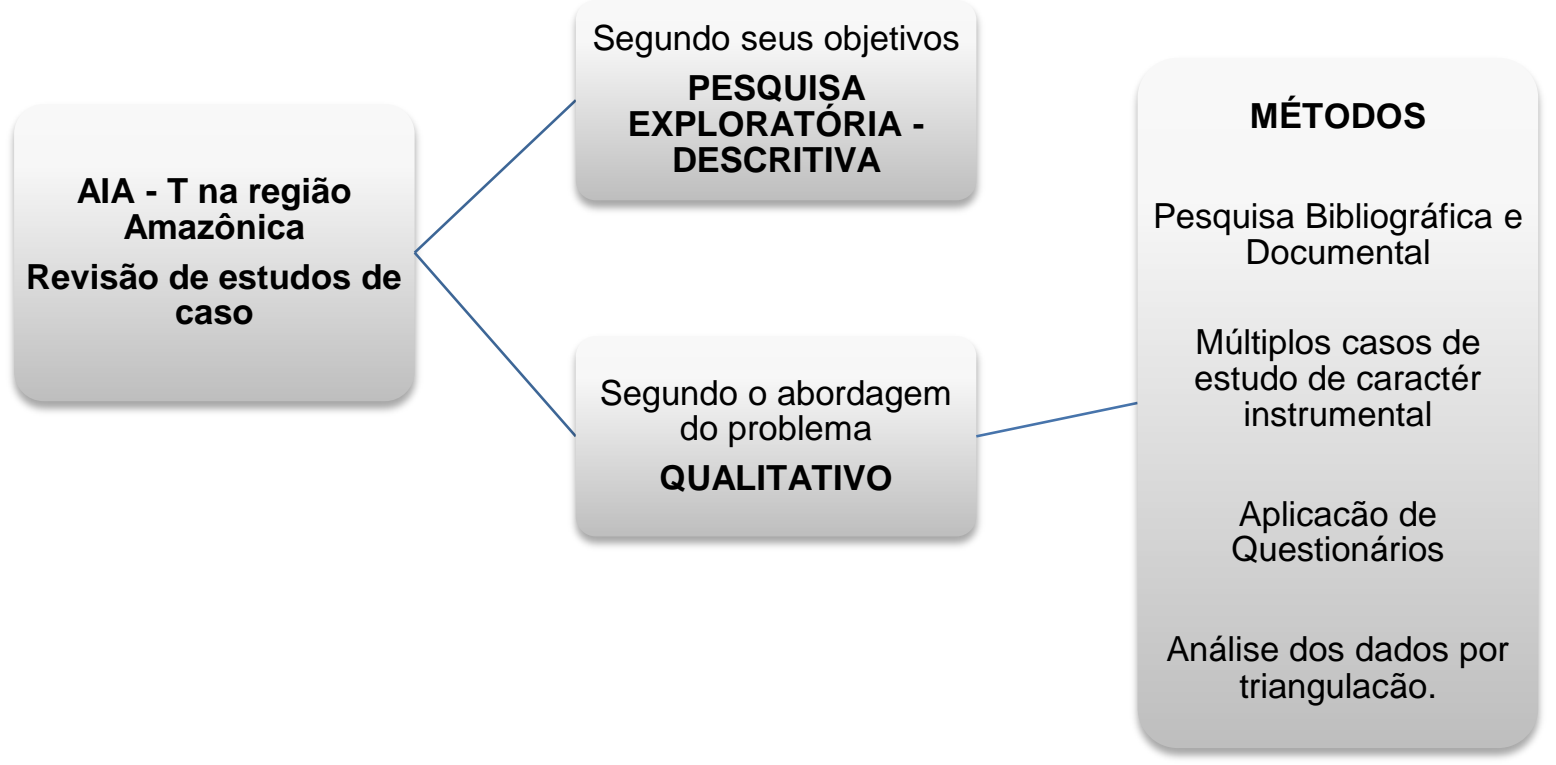

Figura 2 - Abordagem da pesquisa

Esta pesquisa se concentrou em elucidar e descrever as características do quadro institucional e metodológico da AIA - T, e em avaliar a conformidade com seus princípios e boas práticas em nível mundial. Esse objetivo levou à abordagem da pesquisa como descrito na figura 2. 
Segundo Gil (2007), esta pesquisa se classifica como exploratória - descritiva, de acordo com os objetivos propostos, uma vez que ainda não havia uma descrição detalhada que permitisse vislumbrar claramente a forma como era abordada à AIA - T na região Amazônica. Portanto, por meio desta pesquisa, pretendeu-se explicitar e descrever as principais características da AIA - T, para que posteriormente seja suscetível a ser avaliada e melhorada.

O problema apresentado é atual, real e complexo e por isso considerou-se que a melhor maneira de abordá-lo era através de métodos qualitativos. Observa-se que há uma relação dinâmica entre o mundo real e o sujeito de estudo, a fim de compreender os fenômenos que estão sendo estudados a partir da perspectiva dos participantes, considerando todos os pontos de vista como importantes. O ambiente natural é a fonte direta para a coleta de dados, o processo e seu significado são os focos principais de abordagem, de maneira que permita examinar a problemática em seu contexto e em toda sua complexidade(SILVA; MUSZKAT MENEZES, 2005)

\subsection{Etapas e métodos da pesquisa}

Revisão de Literatura

AIAT no contexto mundial - Europa (marco de referência) - América do Sul - Países Amazônicos

Revisão, análise e descrição do marco normativo e institucional dos assuntos ambientais no contexto internacional dos países amazônicos

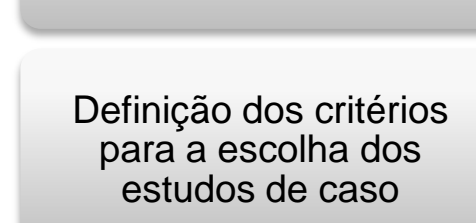

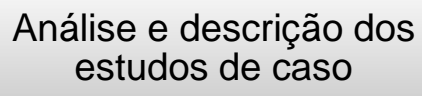

Análise e descrição dos estudos de caso

Análise da conformidade com os princípios da AIAT ao nível mundial
Escolha e descrição do marco de referểncia (Europa)

Comparação do marco Europeu com as práticas nos países amazônicos

Figura 3 - Esquema das etapas da pesquisa 


\subsubsection{Revisão de Literatura.}

Esta fase foi realizada durante o decorrer da pesquisa e foram feitas buscas nas bases de dados Scopus, Web of Science, Scielo, Google, periódicos CAPES, portal SIBI da USP, nas páginas web da Organização do Tratado de Cooperação Amazônica (OTCA), União das Nações Sul-Americanas (UNASUL), Mercado Comum do Sul (MERCOSUL) e Comunidade Andina de Nações (CAN) e dos Ministérios do Ambiente e das Relações Exteriores dos 8 países amazônicos.

As palavras-chave foram ajustadas segundo cada etapa da pesquisa.

Tabela 1- Palavras Chaves usadas na revisão de literatura

\begin{tabular}{|c|c|}
\hline Palavras Chaves & Etapa da pesquisa \\
\hline Transboundary Environmental Impact & \multirow{9}{*}{ Revisão Inicial } \\
\hline Assessment & \\
\hline Transboundary Environmental Assessment & \\
\hline Transboundary Environmental Impact & \\
\hline $\begin{array}{l}\text { Evaluación de Impacto Ambiental } \\
\text { transfronterizo }\end{array}$ & \\
\hline Impacto Ambiental Transfronterizo & \\
\hline Avaliação de Impacto ambiental & \\
\hline Transfronteiriça & \\
\hline Impacto Ambiental Transfronteiriço & \\
\hline $\begin{array}{l}\text { Espoo Aplication } \\
\text { Kiev Protocol }\end{array}$ & Descrição do Marco Europeu \\
\hline Complexo Madeira & \multirow{11}{*}{ Descrição dos estudos de caso } \\
\hline Impactos Ambientais Rio Madeira & \\
\hline Usina hidrelétrica do Rio madeira & \\
\hline Madeira River Dams & \\
\hline Complejo río Madeira & \\
\hline Represa del río Madeira & \\
\hline Interoceanic Higway & \\
\hline Rodovia Interoceânica & \\
\hline Estrada do Pacífico & \\
\hline Carretera Interoceánica & \\
\hline Metodologia EASE - IIRSA & \\
\hline
\end{tabular}

Inicialmente foram analisados os resumos dos artigos e estudos encontrados e segundo sua relevância para a pesquisa foram lidos e analisados em sua totalidade. 


\subsubsection{Escolha e descrição do marco de referência (União Europeia).}

Depois de revisar trabalhos como o de Cassar e Bruch, 2003, transboundary environmental impact assessment in international watercourse management e o de Koivurova e Bastimeijer, 2008, Theory and practice of transboundary environmental impact asseeement, além da revisão da gestão dos impactos transfronteiriços e as experiências em nível mundial, especialmente as da América do Norte, América Central, Ásia e Europa, que serão descritas no marco teórico, observou-se que, dentre eles, a União Europeia contava com uma forte base institucional e tinha aplicações recorrentes com sucesso. De maneira que, com base na revisão de literatura, a União Europeia foi escolhida como o marco de referência. Assim, utilizando as palavras-chave descritas anteriormente, foi analisado e descrito o marco institucional e metodológico empregados naquele contexto, juntamente com alguns casos que tiveram sucesso em sua aplicação.

\subsubsection{Revisão, análise e descrição do marco normativo e institucional dos} assuntos ambientais transfronteiriços no contexto dos países amazônicos.

Nesta seção, foram pesquisadas e analisadas as normativas e os acordos da temática ambiental, relacionadas com a avaliação de impacto ambiental e assuntos ambientais em nível internacional tanto dos países amazônicos quanto dos entes subregionais atuantes na região (OTCA, CAN, MERCOSUL e UNASUL). Além disso, foram revisadas as constituições de todos os países e os documentos que indicassem como os órgãos sub-regionais gerenciam os assuntos ambientais.

Para este propósito foram consultadas as páginas virtuais dos Ministérios do Ambiente e das Relações Exteriores de todos os países, dos sistemas de informação ambiental dos países em estudo, assim como dos órgãos sub-regionais.

Com o propósito de conhecer como são gerenciados os impactos ambientais transfronteiriços desde a ótica dos agentes institucionais responsáveis, optou-se pelo envio de questionários postais. Por considerar que o público-alvo (os escritórios dos países amazônicos relacionados com a gestão ambiental e o gerenciamento dos assuntos ambientais em nível internacional) estava disperso geograficamente, considerou-se este método como uma boa opção para chegar a estes. Os questionários enviados (Apêndice A) foram de resposta direta, fornecidas diretamente pelo pessoal do escritório interrogado, e pós-codificados. Caracterizaram-se por conter perguntas abertas, 
permitindo liberdade ao interrogado de responder sem limitações (ANDER - EGG, 1995).

Estes questionários foram encaminhados via internet, tanto pelos correios eletrônicos quanto pelos sistemas de ouvidoria, sendo este último mecanismo o mais efetivo. Porém, os questionários só foram respondidos pelos países da Colômbia e Brasil (Anexo A). Verificou-se que alguns sistemas de ouvidoria são restritos para os cidadãos desses países, como o Equador, que exige um documento de identificação válido para esse país, e o Peru, que exige ser morador do país.

\subsubsection{Estudos de Caso.}

Esta etapa tem como propósito apresentar uma visão geral de como é aplicada a AIA-T na prática. Os estudos de caso foram selecionados a partir dos seguintes critérios:

$\checkmark$ Projetos que tivessem sido submetidos aos processos de AIA;

$\checkmark$ Que apresentassem impactos transfronteiriços;

$\checkmark$ Com informação suficiente disponível.

Com base nesses critérios, foram escolhidos os casos do Complexo Hidrelétrico do Rio Madeira, da Estrada Interoceânica e da aplicação da metodologia de Avaliação de Impacto ambiental e Social com foco estratégico, EASE - IIRSA.

Para a descrição dos casos foi coletada a maior quantidade possível de informação de diferentes fontes, com o propósito de se ter pontos de vista dos diferentes atores. Desta maneira, no caso do Complexo Hidrelétrico do Rio Madeira foram analisados todos os documentos do processo de licenciamento disponíveis na página do Instituto Brasileiro do Meio Ambiente e dos Recursos Naturais Renováveis - IBAMA. Além disso, foram analisados os estudos feitos tanto pelo governo boliviano, quanto por diversas ONG's, e pelo Ministério Público de Rondônia, entre outros. Também foi realizado um acompanhamento das notícias publicadas em jornais de circulação local, regional e nacional, tanto do Brasil, quanto da Bolívia.

No caso da estrada Interoceânica, foram consultados os processos de AIA disponíveis tanto no Ministério de Transporte no Peru, quanto os processos das Rodovias BR-317 e BR-364 no Brasil, que são as rodovias que dão continuidade à Rodovia Interoceânica em território brasileiro. Além destes, foram analisados os estudos realizados por diversas ONGs, artigos científicos e jornais de circulação local, regional 
e nacional, que tratassem dos casos tanto no território peruano quanto no território brasileiro.

No caso da metodologia EASE, foram analisados todos os casos de aplicação, as lições aprendidas em sua aplicação e os artigos e estudos de análise da proposta, além das atas das reuniões da equipe técnica da UNASUL, encarregada de sua aplicação.

\subsubsection{Análise da conformidade com os princípios da AIA-T em nível mundial}

Fundamentada na análise dos dados das etapas anteriores, foi realizada uma análise da conformidade com os princípios da AIA-T, comparando os princípios da AIA-T definidos nas convenções da Terra de Estocolmo (1972) e Rio (1992), assim como a guia estabelecida na convenção de Espoo (1991), eleitos por definir as boas práticas da AIA-T em nível mundial. Deste modo, os casos foram analisados com base na aplicação ou não destas boas práticas.

\subsubsection{Comparação do marco de referência com os países amazônicos}

Nesta etapa, basicamente foram analisadas as diferentes formas de cumprir os compromissos assumidos pelos países em relação às convenções já citadas, e suas implicações para a prática da avaliação dos impactos transfronteiriços. 


\section{REFERENCIAL TEÓRICO.}

\subsection{Avaliação de Impacto Ambiental e Avaliação Ambiental Estratégica no contexto transfronteiriço.}

O primeiro quadro formal tanto para a Avaliação de Impacto Ambiental (AIA) quanto para a Avaliação Ambiental Estratégica (AAE) encontra-se na Lei de Política Ambiental Nacional americana de 1969 (National Environmental Policy Act, NEPA). Essa lei se tornou efetiva em $1 .^{\circ}$ de janeiro de 1970 . O essencial nessa lei é que visa garantir que o processo de tomada de decisões seja equilibrado em relação ao meio ambiente e ao interesse público. (TETLOW; HANUSCH, 2012) A NEPA surge devido às pressões ambientalistas a partir de meados da década de 60, quando ocorre um aumento da conscientização do público quanto aos problemas de degradação ambiental e suas consequências sociais, levando a uma maior demanda por qualidade ambiental. Essa lei determinava que os objetivos e princípios de legislação, ações e projetos do governo federal norte-americano, que afetassem significativamente a qualidade do meio ambiente humano, deveriam incluir a avaliação de impacto ambiental (ROHDE, $1995^{1}$ apud OLIVEIRA; BURSZTYN, 2001, p.46).

A NEPA influenciou a adoção de políticas similares em quase todos os países do mundo, inicialmente nos países desenvolvidos, depois suas exigências foram adotadas por agências de cooperação internacional e finalmente pelas organizações financeiras internacionais. Estas últimas passaram a exigir como condição para empréstimos a observância dos estudos da AIA, por causa da pressão de ONGs e dos países desenvolvidos, que passaram a responsabilizar - as pelos problemas ambientais dos países em desenvolvimento. Assim, estas organizações tiveram um papel representativo na difusão das políticas de AIA nos países em desenvolvimento(SÁNCHEZ, 2008).

De acordo com Egler $^{2}$ (1998 apud OLIVEIRA; BURSZTYN, 2001, p.46), o principal propósito da NEPA era a consideração de efeitos ambientais de Políticas,

\footnotetext{
${ }^{1}$ ROHDE, Geraldo Mário. Estudos de impacto ambiental: a situação brasileira. In: VERDUM, Roberto; MEDEIROS, Rosa Maria Vieira. RIMA, Relatório de Impacto Ambiental: legislação, elaboração e resultados. 3. ed. ampl. Porto Alegre, Universidade/UFRGS, 1995. p. 20- 36.

${ }^{2}$ EGLER, Paulo César Gonçalves. Improving the EIA Process in Brazil. Inglaterra, 1998. Tese (Doutorado em Ciências Ambientais) - University of East Anglia.
} 
Planos e Programas (PPPs), isso pode ser identificado desde os estágios iniciais da sua elaboração. No entanto, sua evolução resultou na consolidação do processo de avaliação de impacto ambiental baseado em projetos (FERREIRA; BETENCOURT; FREITAS, 2012; OLIVEIRA; BURSZTYN, 2001).

Dessa forma, a Avaliação de Impacto Ambiental (AIA) tem como finalidade considerar os impactos ambientais antes de se tomar qualquer decisão que possa acarretar significativa degradação da qualidade do ambiente. Para isso, visa estimular a consideração de fatores ambientais nos processos de planejamento e tomada de decisão, de modo que as ações públicas e privadas implementadas sejam mais compatíveis com o meio ambiente. Assim, esta ferramenta é voltada para a análise da viabilidade ambiental de uma proposta (SÁNCHEZ, 2008).

O processo de avaliação de impacto ambiental é amplo e abrange atividades que precedem ou que seguem a avaliação propriamente dita. Esse processo pode iniciar com uma fase de identificação prévia dos impactos mais importantes e das questões mais relevantes a serem considerados na avaliação ("scoping"), e finalizar com um programa de acompanhamento dos efeitos ambientais durante a fase de implementação do projeto. O processo de AIA é composto de uma sucessão de etapas, que se encadeiam e se inter-relacionam sistematicamente (OLIVEIRA; BURSZTYN, 2001). Os objetivos da avaliação de impacto ambiental são:

$\checkmark$ Assegurar que o ambiente é explicitamente considerado e incorporado no processo de decisão sobre propostas de desenvolvimento;

$\checkmark$ Antecipar e evitar, minimizar ou compensar os efeitos adversos significativos - biofísicos, sociais e outros relevantes - de propostas de desenvolvimento;

$\checkmark$ Proteger a produtividade e a capacidade dos sistemas naturais e dos processos ecológicos que mantêm as suas funções;

$\checkmark$ Promover um desenvolvimento que seja sustentável e que otimize o uso dos recursos e as oportunidades de gestão (IAIA; IEA, 1999).

De fato a Avaliação de Impacto Ambiental (AIA) realizada no tempo e na forma correta é necessária, mas em muitos casos não é suficiente. A AIA em contextos transfronteiriços não só deverá satisfazer os requerimentos legais e dos procedimentos, além de servir para melhorar os projetos, evitar ou reduzir impactos; deverá permitir a participação pública significativa da população dos países envolvidos e a cooperação e entendimento entre países vizinhos (PIRILLO, 2011). 
O processo de AIA de projetos é geralmente limitado aos impactos diretos do projeto e tem serias limitações para identificar impactos cumulativos, induzidos, sinérgicos e globais derivados da atuação de vários projetos num mesmo tempo e lugar (OLIVEIRA; BURSZTYN, 2001). Tais deficiências decorrem de duas ordens de causas: dificuldade ou mesmo impossibilidade de obter informação sobre outros projetos presentes e sobre projetos futuros, problemas de planejamento e condução dos estudos ambientais (SÁNCHEZ, 2008). Conforme Pirillo (2011), estes aspectos são importantes no contexto transfronteiriço, por ser necessária, em algumas oportunidades, a avaliação de vários projetos em uma ecorregião.

Estas limitações da AIA de projetos poderiam ser superadas se fosse efetuada uma análise nas primeiras etapas da planificação, na qual poderiam-se incorporar questões ambientais de forma intrínseca ao planejamento de ações estratégicas, influenciando o contexto em que as decisões são tomadas e permitindo a consideração de alternativas e medidas de mitigação que vão além dos limites de projetos individuais. Neste sentido, a Avaliação Ambiental Estratégica (AAE) se apresenta como uma ferramenta que contribui para completar a inclusão dos aspectos ambientais nos processos de planejamento, oferecendo um contexto mais adequado para a consideração de impactos cumulativos, sinérgicos, induzidos e globais, que tem uma aplicabilidade importante no contexto transfronteiriço (BINA, 2007; OLIVEIRA; BURSZTYN, 2001; PIRILLO, 2011; TETLOW; HANUSCH, 2012).

A AAE é considerada como um processo contínuo, que facilita um enfoque pró-ativo para assegurar que as considerações ambientais e de sustentabilidade são tidas em conta durante as primeiras etapas dos processos de tomada de decisão, além de ter um papel importante em facilitar o pensamento estratégico e a integração na tomada de decisões (LOBOS; PARTIDARIO, 2014; PARTIDÁRIO, 2007; TETLOW; HANUSCH, 2012). Tem três funções importantes: a Integração das questões ambientais e de sustentabilidade nos processos estratégicos, a avaliação das oportunidades e riscos das opções estratégicas e a validação da avaliação de processos e resultados estratégicos (PARTIDÁRIO, 2007)

Esta ferramenta pode ser aplicada em muitos níveis diferentes de atividades estratégicas. Ela pode ser aplicada em Políticas, Planos e Programas territoriais, setoriais ou em assuntos específicos como Mudanças Climáticas ou Biodiversidade, sendo o campo do ordenamento territorial uma das aplicações de mais sucesso. Geralmente, os campos de aplicação da AAE dentro de qualquer país dependerá dos 
tipos de associações público-privadas e as disposições específicas da AAE em cada país (TETLOW; HANUSCH, 2012).

Uma AAE de boa qualidade informa aos tomadores de decisões e ao público afetado sobre a sustentabilidade de decisões estratégicas, facilita a busca das melhores alternativas e assegura um processo de tomada de decisões democrático. Isso contribui para a credibilidade das decisões e ajuda a melhorar a efetividade em tempo e dinheiro dos projetos que virão (IAIA, 2002).

Não existe uma AAE igual à outra; é necessário analisar cada região envolvida, cada sociedade, cada história dos povos. Deste modo, o enfoque regional deveria cobrar maior importância, no qual a prioridade seja a unidade funcional ambiental, enfoque de especial aplicação nos casos de planificação de espaços transfronteiriços entre países vizinhos (PIRILLO, 2011).

\subsection{Avaliação Ambiental Transfronteiriça}

Os recursos naturais compartilhados e a exploração dos mesmos pelos países têm trazido conflitos ao longo da historia. Por muitas décadas, principalmente após a declaração de Estocolmo em 1972, os países perceberam que o ambiente não observa fronteiras políticas e que os impactos transfronteiriços também devem ser levados em consideração na tomada de decisões. A experiência com a Avaliação de Impacto Ambiental Transfronteiriça (AIA-T) tem sido crescente desde aquele momento (SCHRAGE; BONVOISIN, 2008).

Em 1941 se conhece a primeira manifestação formal do Direito Internacional do Meio Ambiente respeito às relações bilaterais, inspirado pelo caso da fundição Trail, resolvida definitivamente somente a partir da atuação de um tribunal arbitral. Tratava-se de uma reclamação apresentada pelos EUA contra o Canadá, devido a ocorrências danosas de poluição transfronteiriça suportadas por pessoas, animais e bens situados nos EUA, causadas por correntes de ar que traziam partículas e fumaça tóxica (dióxido de enxofre) produzidas no Canadá, por uma empresa particular. A parte principal da sentença, assim está redigida: "Nenhum Estado tem o direito de usar ou de permitir o uso de seu território de tal modo, que cause dano em razão do lançamento de emanações no, ou até o território de outro". Esta sentença tem servido de precedente a inúmeras 
decisões arbitrais posteriores (BASTMEIJER; KOIVUROVA, 2008a; FERREIRA; BETENCOURT; FREITAS, 2012)

A partir deste caso, o mundo acadêmico passa a apresentar muitas formulações do princípio de não-prejuízo que iria reger a responsabilidade dos estados para a poluição ambiental transfronteiriça. Um consenso sobre uma versão expandida de tal princípio começou a surgir quando a Declaração de Estocolmo 1972 foi adotada (BASTMEIJER; KOIVUROVA, 2008a). O princípio 21 da Declaração em particular, foi cada vez mais citado como a formulação de autoridade:

[...]Os Estados, de acordo com a Carta das Nações Unidas e dos princípios do direito internacional, tem o direito soberano de explorar seus próprios recursos segundo suas próprias políticas ambientais (e de desenvolvimento) e a responsabilidade de assegurar que as atividades sob sua jurisdição ou controle não causem danos ao meio ambiente de outros Estados ou de áreas além da jurisdição nacional (ONU, 1972).

No âmbito do Direito Internacional a Avaliação de Impacto Ambiental Transfronteiriço está associada aos seguintes elementos:

1. O Direito Internacional proíbe a contaminação transfronteiriça, conforme estabelece o princípio 21 da declaração de Estocolmo, segundo a qual os países não podem causar danos ao meio ambiente de outros estados ou áreas além da jurisdição nacional.

2. Para assegurar que as atividades dentro de sua jurisdição não causarão dano transfronteiriço, os estados devem avaliar os possíveis efeitos transfronteiriços das atividades.

3. Para isso, os estados assinam acordos internacionais que os obrigam a realizar a Avaliação de Impacto Ambiental Transfronteiriça (AIA-T) para as atividades que possam causar este tipo de danos (KNOX, 2002).

A Avaliação de Impacto Ambiental Transfronteiriça (AIA-T) é definida como a avaliação dos efeitos ambientais de propostas de projetos que são originados em uma jurisdição e têm efeitos em outras. Esta definição é de particular interesse para o direito porque se trata da interação entre os sistemas jurídicos, que podem ser iguais ou diferentes. Além de ter condicionamentos especiais pela incidência na interação jurídica e política entre os países envolvidos, especialmente em temáticas delicadas como a segurança nacional, a autonomia e soberania (MARSDEN, 2011b; PIRILLO, 2011; ROJAS et al., 2006). 
O processo de análise de impacto se amplia a uma área geográfica que pertence administrativamente a outro país. Os métodos e procedimentos não variam para a realização da AIA; o que tem relevância é a interação entre ambos países para permitir que seu país vizinho tenha opinião na análise da AIA do projeto e sua consequente licença ambiental (ROJAS et al., 2006).

Assim, a avaliação dos impactos transfronteiriços foi realizada por muitos anos, mas só recentemente está se tornando prática usual na Europa em nível de projetos. Isto está ocorrendo por causa de um quadro legal claro, incluindo acordos bilaterais e multilaterais, e uma longa experiência na busca de soluções para os muitos problemas práticos. No entanto, muitos desafios permanecem, especialmente em regiões com pouca clareza ou fracas disposições para a AIA-T e para decisões mais estratégicas nas quais se tem pouca experiência, nomeadamente em matéria de políticas, planos e programas suscetíveis a ter efeitos transfronteiriços significativos e para atividades transfronteiriças. Além disso, em muitos casos, os requisitos ou normas que a regem são gerais e excessivamente vagos, deixando os critérios a quem a dirige (BRUCH et al., 2008; SCHRAGE; BONVOISIN, 2008).

Quando usada corretamente, a AIA-T pode ser uma ferramenta para a tomada de decisão poderosa, podendo, deste modo, ajudar a identificar e avaliar os potenciais impactos ou analisar os impactos de formulações alternativas de uma proposta de projeto ou atividade e fornecer uma base de informação para determinar como proceder. Ainda baseando-se em metodologias de AIA nacionais e o reconhecimento de que abordagens mais eficazes são necessárias para considerar possíveis impactos internacionais, um corpo crescente de direito, política e prática estabeleceu que a Avaliação de Impacto Ambiental Transfronteiriça é uma ferramenta essencial de gestão ambiental (CASSAR E BRUCH, 2004; TROELL et al, 2005 apud BRUCH et al., 2008)

Convenções globais, iniciativas regionais, acordos bilaterais, políticas de desenvolvimento dos bancos, leis nacionais e jurisprudência internacional frequentemente exigem que os tomadores de decisões realizem uma avaliação do

\footnotetext{
${ }^{3}$ Cassar, A Z and C E Bruch 2004. Transboundary environmental impact assessment in international watercourses. New York University Environmental Law Journal, 12, 169-244.

${ }^{3}$ Troell, J, C Bruch, A Cassar and S Schang 2005. Transboundary environmental impact assessment as a tool for promoting public participation in international watercourse management. In Enhancing Participation and Governance in Water Resources Management: Conventional Approaches and Information Technology, eds. L Jansky and J I Uitto. Tokyo: UNU Press.
} 
potencial de impactos ambientais transfronteiriços, sociais e ou econômicos antes de tomar uma decisão sobre a continuidade ou não dos projetos (BRUCH et al., 2008).

Vários autores concordam em que a AIA - T é uma ferramenta importante, especialmente em um contexto globalizado, com ambiciosos projetos que envolvem mais de um país. Esta ferramenta, portanto, tem o potencial de reforçar a cooperação internacional, a sensibilização em quanto à importância do ambiente e para evitar o conflito entre países vizinhos (SCHRAGE; BONVOISIN, 2008).

Através dos estudos e experiências neste campo tem-se identificado algumas ações características deste processo que não são aplicáveis numa sequencia linear simples. Tem-se encontrado alguns inconvenientes para sua aplicação. Na seguinte tabela são apresentadas estas considerações, tanto das ações que caracteriza a AIA-T quanto das dificuldades encontradas na prática para sua aplicação.

Tabela 2 - Características da Avaliação de Impacto Ambiental Transfronteiriça e suas dificuldades na aplicação

\begin{tabular}{|c|c|}
\hline & 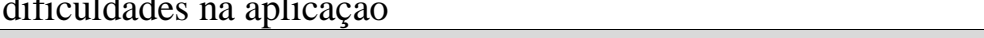 \\
\hline Ações Características & Dificuldades na aplicação da AIA - T \\
\hline $\begin{array}{l}\text { A notificação pelo "país de } \\
\text { origem" ao "país afetado" ou } \\
\text { países, informando uma atividade } \\
\text { planejada que pode ter um } \\
\text { impacto significativo ou efeitos } \\
\text { ambientais no território deste } \\
\text { último. (A notificação também } \\
\text { pode fornecer informações sobre } \\
\text { a atividade planejada, seus } \\
\text { prováveis efeitos transfronteiriços } \\
\text { significativos e sobre o processo } \\
\text { de licenciamento e tomada de } \\
\text { decisão.) }\end{array}$ & $\begin{array}{l}\text { Problemas com a identificação dos pontos de contato: Quem } \\
\text { contatar para diferentes tipos de atividades, em diferentes } \\
\text { setores e em diferentes níveis de governo? Isso pode se tornar } \\
\text { mais complexo para um governo mais descentralizado. }\end{array}$ \\
\hline $\begin{array}{l}\text { Uma resposta pelo país afetado, } \\
\text { indicando se deseja ser } \\
\text { consultado sobre o assunto. }\end{array}$ & $\begin{array}{l}\text { A falta de resposta. Se o país afetado não responder à } \\
\text { notificação, não está claro se isso significa que ele não deseja } \\
\text { ser consultado. Surge então a questão de se continuar a enviar } \\
\text { informações. }\end{array}$ \\
\hline Compartilhamento de informação & Problemas de linguagem em relação \\
\hline
\end{tabular}




\begin{tabular}{l|l}
\hline \multicolumn{1}{c|}{ Ações Características } & \multicolumn{1}{c}{ Dificuldades na aplicação da AIA - T } \\
\hline entre os países envolvidos. & $\begin{array}{l}\text { documentos e interpretação durante as reuniões. } \\
\text { Desacordo sobre quando a documentação tem que ser } \\
\text { traduzida, em que línguas, por quem (proponente da atividade, } \\
\text { o governo central, o país afetado, etc), e quem paga. }\end{array}$ \\
\hline
\end{tabular}

Acesso limitado à documentação pelo público do país afetado (sendo cauteloso em excesso de confiança na Internet, que é um mecanismo particularmente atraente em AIA-T, mas que podem excluir grupos desfavorecidos).

A preparação de documentação de Estudos de Impacto Ambiental que aborde os efeitos transfronteiriços.

Falta de dados que forneçam uma linha-base confiável para o processo de AIA-T. Normalmente, o processo de realização de uma avaliação requer a coleta de dados de base. Na prática, frequentemente o tempo para a coleta de dados é insuficiente, o que leva à coleta de dados poucos confiáveis; como consequência, o processo de AIA-T é baseado muitas vezes em predições qualitativas e evidencias anedóticas.

A distribuição da documentação Acesso limitado às audiências públicas se realizadas apenas da AIA, possivelmente traduzido, para o país afetado. no país de origem (despesas de viagens, restrições de fronteira, necessidade de interpretação, etc.)

Falta de vontade do público do país afetado em participar de Consulta entre as autoridades dos países em questão. processos que implicam atividades em outro país, pois são atividades que podem não parecer concretas, especialmente quando são políticas, planos e programas.

Falta de equidade e igualdade nas oportunidades de Participação do público no país afetado. participação entre o público do país de origem e o país afetado.

Dúvidas sobre quem é o responsável de envolver o público no país potencialmente afetado.

A tomada de uma decisão sobre a Incerteza sobre o momento da notificação. Os efeitos atividade pelo país de origem, transfronteiriços podem ser identificados durante a elaboração tendo em conta a documentação da AIA e comentários recebidos das autoridades e do público no da AIA ou documentação AAE. Porém, se identificados anteriormente, seria melhor que uma notificação informal fosse fornecida mais cedo, como, por exemplo, durante 


\begin{tabular}{|c|c|}
\hline Ações Características & Dificuldades na aplicação da AIA - T \\
\hline país afetado. & $\begin{array}{l}\text { escopo. Se isso for feito, podem-se reduzir atrasos em chegar } \\
\text { à fase de decisão. }\end{array}$ \\
\hline $\begin{array}{l}\text { O compartilhamento de } \\
\text { informações com o país afetado } \\
\text { sobre a decisão tomada e, em } \\
\text { alguns casos, a possibilidade de } \\
\text { um apelo do país afetado contra a } \\
\text { decisão. }\end{array}$ & $\begin{array}{l}\text { Os atrasos na execução da atividade. O processo de consulta } \\
\text { transfronteiriça pode alongar significativamente o processo de } \\
\text { aprovação, devido a atrasos na notificação ou espera por uma } \\
\text { resposta de um país potencialmente afetado, tradução da } \\
\text { documentação adicional de consulta e participação pública, } \\
\text { etc.. }\end{array}$ \\
\hline $\begin{array}{l}\text { Possivelmente, e de preferência, } \\
\text { monitoramento e análise após o } \\
\text { projeto. }\end{array}$ & $\begin{array}{l}\text { Incompatibilidade dos sistemas nacionais de avaliação de } \\
\text { impacto e participação do público (por exemplo, o tempo } \\
\text { permitido para as diferentes fases; participação pública na } \\
\text { scoping), o que pode conduzir a dificuldades práticas, } \\
\text { incluindo atrasos e problemas de equidade. }\end{array}$ \\
\hline \multirow[t]{3}{*}{$\begin{array}{l}\text { O apoio dos altos níveis políticos } \\
\text { é fundamental para o } \\
\text { desenvolvimento dos processos } \\
\text { de AIA-T com sucesso. }\end{array}$} & $\begin{array}{l}\text { Falta de consenso sobre quem cobre os custos incorridos no } \\
\text { país afetado, incluindo os custos de audiências públicas e da } \\
\text { análise da documentação pelo governo. }\end{array}$ \\
\hline & $\begin{array}{l}\text { Interesses políticos e comerciais nacionais interferindo com o } \\
\text { procedimento da AIA. } \\
\text { A coordenação de governo para governo e da diplomacia } \\
\text { acrescenta outra dimensão a um processo já difícil. }\end{array}$ \\
\hline & $\begin{array}{l}\text { A falta de um quadro jurídico claro dificulta os processos. Os } \\
\text { estudos de caso destacam a importância de se ter um conjunto } \\
\text { claro de requisitos jurídicos, processuais e institucionais sobre } \\
\text { como conduzir, analisar e finalizar a AIA - T. }\end{array}$ \\
\hline
\end{tabular}

Fonte: Compilado de Bastmeijer e Koivurova (2008); Bruch Et Al. (2008) e Schrage e Bonvoisin ( 2008)

Uma das lições aprendidas com a experiência geral internacional com AIA-T é que um alto nível de apoio político é necessário. A política pode ajudar o processo ou pode complicar e impedi-lo, especialmente se certos resultados são prescritos ou proibidos (BRUCH et al., 2008). Garantir o apoio político é particularmente importante 
para superar as questões de soberania e da incompatibilidade dos sistemas nacionais, mas também é necessário para permitir a implementação efetiva do princípio da não discriminação, dada a reconhecida importância da participação pública significativa (MARSDEN, 2011b).

\subsection{AVALIAÇÃO AMBIENTAL TRANSFRONTEIRIÇA NO CONTEXTO MUNDIAL}

No âmbito do Direito Internacional, as bases da AIA-T são encontradas nos princípios estabelecidos nas convenções mundiais de Estocolmo (1972), princípios 20, 21, 22 e 24 e Rio de Janeiro (1992), princípios 2, 4, 7, 12, 15, 18 e 19, dentre os quais sobressaem os princípios da soberania dos estados sobre seus recursos naturais sem danar os recursos naturais dos países vizinhos, da boa vizinhança e da precaução, cooperação internacional e notificação como os princípios que fundamentam a aplicação da Avaliação de Impacto Ambiental Transfronteiriça. Dentre estes, o principio 21 de Estocolmo tem uma grande importância por considerar que a AIA-T dá resposta processual a este principio (BASTMEIJER; KOIVUROVA, 2008b; ROJAS; IZA; CEDEÑO, 2006).

Recentemente, cada vez mais blocos de países, além da União Europeia, têm abordado de maneira formal a AIA-T, tornando-se conscientes da necessidade de considerar o desenvolvimento destes procedimentos. Particularmente em regiões de países com crescimento econômico relativamente rápido, a AIA-T está tomando um lugar na agenda política (BASTMEIJER; KOIVUROVA, 2008b).

O desenvolvimento dos sistemas de AIA tem-se globalizado nos últimos anos. Porém, o potencial de Impactos Transfronteiriços gerados pelos grandes projetos exigem que os governos considerem se os processos de AIA nacionais são suficientes para garantir uma adequada avaliação dos impactos transfronteiriços, já que a aplicação das legislações de AIA nacionais sem a existência de acordos ou diretrizes internacionais podem transferir suas limitações ao processo transfronteiriço, como limitações no escopo do processo e incertezas no tempo, devido a que os sistemas de AIA nacionais estão sujeitos às reformas internas de cada país ou à aplicação desigual entre as partes (BASTMEIJER; KOIVUROVA, 2008b). 
Por considerar as limitações dos sistemas nacionais de AIA, cada vez mais países têm decidido cooperar para desenvolver diretrizes ou acordos sobre AIA-T e não se basear só na aplicação dos sistemas nacionais de AIA, trazendo assim maior claridade processual ao processo de AIA-T e filtrando as limitações dos sistemas de AIA nacionais. Além disso, é importante destacar que as políticas ambientais de instituições financeiras e outras organizações envolvidas em projetos de desenvolvimento têm constituído um impulso adicional para um maior foco na AIA-T (BASTMEIJER; KOIVUROVA, 2008b).

A AIA-T pode ser acelerada e simplificada através do desenvolvimento de acordos bilaterais ou multilaterais que fornecem uma estrutura de ligação recíproca para notificação transfronteiriça e para consultas. Com efeito, nos últimos anos, uma série de enquadramentos legais foram desenvolvidos a fim de fornecer uma estrutura para a avaliação do impacto transfronteiriço. Alguns destes são: (i) a Convenção sobre Avaliação de Impacto Ambiental no contexto transfronteiriço, adotado e assinado em Espoo (Finlândia) em 1991 e seu protocolo sobre Avaliação Ambiental estratégica, adotado e assinado em Kiev 2003; (ii) diferentes diretivas europeias sobre o tema; (iii) o protocolo sobre AIA-T da região do mar Cáspio; (iv) o projeto de acordo norteamericano a meados da década de 1990; (v) além de numerosas experiências sobre a aplicação de AIA - $\mathrm{T}$ em diversas regiões do mundo como África e Ásia (BASTMEIJER; KOIVUROVA, 2008a; SCHRAGE; BONVOISIN, 2008)

A seguir serão apresentadas algumas experiências identificadas no cenário mundial.

\subsubsection{Europa.}

Os países europeus, especialmente os pertencentes à União Europeia, evoluíram cedo nos princípios e práticas da AIA-T, em parte por sua necessidade geográfica e em parte como reflexo das formas de integração em desenvolvimento. Assim, em 1985, a União Europeia adotou uma diretiva, a 85/337/CEE, relativa à avaliação das repercussões de determinados projetos sobre o meio ambiente. Dentre suas disposições no artigo 7, foram especificadas obrigações a serem cumpridas quando existem impactos transfronteiriços (CASSAR; BRUCH, 2003).

Depois, sob o auspício da Comissão Econômica das Nações Unidas para Europa (UNECE), foi negociada, adotada e implementada a convenção sobre avaliação de impactos ambientais em contexto transfronteiriços, a qual foi assinada por todos os 
países europeus além da Ásia Central, Canadá e Estados Unidos (CASSAR; BRUCH, 2003). Assim, em Fevereiro de 1991, em Espoo, Finlândia, foi assinada a Convenção sobre Avaliação de Impactos Ambientais em contextos transfronteiriços, a qual entrou em atividade em setembro de 1997. Considera-se como o tratado internacional mais importante e influente sobre a AIA-T, pois define as obrigações e os direitos mínimos dos países assinantes com respeito aos impactos transfronteiriços (BASTMEIJER; KOIVUROVA, 2008b; CASSAR; BRUCH, 2003; PIRILLO, 2011).

A Convenção de Espoo é fundamental na evolução do Direito Internacional ambiental vinculado com instrumentos preventivos, juntamente com as Diretivas Comunitárias. Desta forma, ambos têm contribuído para o estabelecimento de um marco regulatório para a AIA no contexto europeu mais amplo que o comunitário e não exclusivamente limitado a questões nacionais, mas também para aquelas que excedem as fronteiras. Deste modo, pode ser considerado como um modelo de referência válido para todos aqueles blocos de países que se encaminham para a adoção de uma normativa uniforme na matéria (CASSAR; BRUCH, 2003; ROJAS et al., 2006).

A Espoo prevê um quadro concreto de regulamento processual de atividades prejudiciais ao meio ambiente, possui diversos recursos e é um dos mais progressistas acordos ambientais multilaterais (Multilateral Environmental Agreement - MEAs). Esta convenção visa prevenir, reduzir e controlar os impactos ambientais transfronteiriços significativos a partir de atividades propostas pela institucionalização de um processo padronizado de avaliação de impacto ambiental transfronteiriço (COMISIÓN ECONÓMICA PARA EUROPA, 1991; KOYANO, 2008). O objetivo é tornar as atividades propostas sujeitas a um processo padronizado de AIA transfronteiriça, em vez de regular substancialmente as atividades propostas. Poucos MEAs contêm tais procedimentos bem elaborados. Assim, a Convenção de Espoo visa atingir não apenas interesses bilaterais entre as partes contratantes diretamente envolvidas com a atividade proposta, mas também os interesses comuns de todas as partes contratantes(KOYANO, 2008).

O Protocolo de Avaliação Ambiental Estratégica para a Convenção sobre a Avaliação do Impacto Ambiental em um Contexto Transfronteiriço foi adotado em 21 de maio de 2003, em Kiev, Ucrânia. Seu objetivo é o estabelecimento dos procedimentos para avaliar certos planos e programas, nos quais garanta que serão tidas em conta as considerações dos efeitos ambientais e sobre a saúde. Este Protocolo estabelece as bases para a AAE de acordo com o estipulado pela Convenção de Espoo e 
Convenção de Aarhus e desenvolve uma série de procedimentos relativos a um listado taxativo, avaliação ambiental inicial, participação pública, consultas, consultas transfronteiriças, dando um importante seguimento a relação da AAE com políticas e legislações existentes (MARSDEN; KOIVUROVA, 2011).

\subsubsection{Região do Mar do Cáspio.}

Esta região esta rodeada por cinco países costeiros: a República do Azerbaijão, a Republica Islâmica do Irã, a República do Cazaquistão, a Federação Russa e Turcomenistão. O Mar Cáspio é o corpo de água mais grande sobre a terra rodeado por terra. O isolamento da bacia do Cáspio, junto com as condições climáticas e os gradientes de salinidade, têm criado um sistema ecológico único. Porém, esta região tem grandes reservas de gás e petróleo, o que desperta grande interesse econômico. Por este motivo, os estados costeiros, junto com organizações internacionais como a EC, UNDP, UNEP e o banco Mundial, estabeleceram o programa Ambiental do Mar Cáspio (CEP) em 1998 como um programa regional guarda-chuva, que tem a missão de ajudar aos estados do Mar Cáspio a alcançar os objetivos do desenvolvimento sustentável com o meio ambiente e a gestão do meio ambiente do Cáspio (TSUTSUMI; ROBINSON, 2008).

Assim, depois de oito anos de negociações, a convenção-marco para a proteção do meio marino Cáspio, a Convenção de Teerã, foi assinada pelos cinco estados litorais em novembro de 2003 e entrou em vigor em agosto de 2006, depois da ratificação dos cinco países, assinalando a vontade e o compromisso de trabalhar juntos para proteger o meio ambiente do Mar Cáspio (TSUTSUMI; ROBINSON, 2008).

Neste contexto, era necessário ter procedimentos claros para a AIA-T. Porém só três dos cinco países costeiros são signatários da convenção de Espoo, e só dois deles a têm ratificado, razão pela qual foi necessária a criação de um acordo neste sentido, não só para a proteção do ambiente, mas também por terem de lidar com as grandes empresas petroleiras. Por esse motivo, em 2004 se iniciou a construção de um protocolo para a avaliação dos impactos ambientais num contexto transfronteiriço na região (TSUTSUMI; ROBINSON, 2008).

A convenção de Espoo foi a base para a construção deste protocolo, já que esta convenção provém de um marco processual geral para a AIA-T e leva suas partes a fazerem acordos bilaterais ou multilaterais para cumprir com suas obrigações e elaborar 
detalhes específicos para realizar o procedimento de AIA-T (TSUTSUMI; ROBINSON, 2008).

Assim, no marco da convenção de Teerã, foi realizado o protocolo para AIA-T para a região do Mar Cáspio, seguindo como fio condutor a convenção de Espoo, com algumas particularidades da região, como no processo de notificação ao país afetado, além da carta informando a situação e enviando toda a informação pertinente em um pacote, não só ao país afetado, mas também para a Secretaria da Convenção de Teerã, que depois pode disponibilizar a informação em seu site, o que pode permitir que a população de todos os países da região estejam em dia com a informação do projeto, assim estes não sejam afetados pelo projeto diretamente (TSUTSUMI; ROBINSON, 2008).

\subsubsection{América do Norte}

A América do Norte está composta por três países federais, Canadá, Estados Unidos e México, que comparados com os países europeus tem área geográfica maior e densidade populacional menor e a natureza de seus assuntos transfronteiriços são principalmente binacionais, o que tem influído no pouco avanço no desenvolvimento de acordos ou marcos estruturados para AIA-T comparado com Europa, apesar de ter uma longa história de experiências práticas em atividades relativas à AIA-T (CASSAR; BRUCH, 2003).

Desde meados da década de 1990, Canadá, México e Estados Unidos têm buscado negociações para um acordo norte-americano sobre a AIA transfronteiriça, sob os auspícios da Comissão Norte-americana para a Cooperação Ambiental (NACEC), que faz parte da NAFTA. Estas negociações produziram um projeto de acordo, em 1998, mas ele ainda tem que ser desenvolvido para se tornar um tratado. O projeto sugere que os negociadores pretendem alargar os seus atuais procedimentos internos de AIA para incluir efeitos transfronteiriços de uma forma não discriminatória, como a Convenção de Espoo faz, garantindo a notificação oportuna ao país afetado (minimamente no mesmo momento em que informar ao público do país de origem), a participação efetiva da população do país potencialmente afetado e a garantia de que suas opiniões e sugestões serão consideradas. Contudo, ao contrário do modelo integracionista europeu, as instituições da NAFTA não são supranacionais. Isso significa que os países membros do acordo, Estados Unidos, Canadá e México, devem adotar legislação e regras próprias para lidar com os assuntos de sua agenda, inclusive 
com as questões relacionadas ao meio ambiente (BASTMEIJER; KOIVUROVA, 2008a; KNOX, 2002; QUEIROZ, 2005).

Dessa forma, em virtude das dificuldades que surgem por haver legislações com diferentes graus de comprometimento com a temática ambiental, os objetivos relativos às questões do meio ambiente devem ser alcançados por intermédio da cooperação, já que conforme observado anteriormente, prevalecem as normas jurídicas internas de cada país de acordo com o seu nível de interesse sobre o assunto. Entretanto, no caso de haver disputas sobre medidas ambientais entre os membros da NAFTA cuja resolução não seja alcançada pelo simples entendimento entre as partes, cabe ao Mecanismo de Solução de Controvérsias, previsto no Tratado, legislar sobre a questão(QUEIROZ, 2005).

Uma das maiores limitações para concretizar o acordo entre estes três países é a reticência destes quanto a fazer ajustes importantes em seus programas nacionais de AIA, pois suas debilidades prejudicam a abordagem adequada dos impactos transfronteiriços. Entre as debilidade é destacada a falta de coordenação entre os governos federais e estatais, já que cada um tem suas próprias regras para AIA-T, motivo pelo qual não há reciprocidade de trato entre países. O resultado tem sido uma série de importantes controvérsias entre os estados no que se refere á aplicação e adequação dos processos internos de AIA para projetos com impactos transfronteiriços (CRAIK, 2008).

\subsubsection{América Central}

A América Central esta composta por sete países continentais: Guatemala, Belize, El Salvador, Honduras, Nicarágua, Costa Rica e Panamá, todos com governos democráticos e compartilhando agendas similares com o fim de melhorar suas economias, tanto em nível nacional quanto regional. É reconhecido que o aumento das atividades econômicas na região pode ter efeitos adversos graves nas comunidades locais e no meio ambiente, que podem chegar a ser transfronteiriços; o reconhecimento destas ameaças tem-se traduzido em iniciativas concretas em relação à harmonização das políticas, legislações e as práticas na região (CEDEÑO, 2008).

Inicialmente, os processos de AIA nos países da América Central foram desenvolvidos por pressão de organismos internacionais multilaterais, fundamentalmente pelo Banco Mundial e o Banco Interamericano de Desenvolvimento. Atualmente, todos estes países contam com leis de AIA internas, mas com alguns 
problemas como a limitada capacidade técnica e de orçamento, o que traz a baixa fiscalização e seguimento; a participação pública é cumprida de maneira mínima pelos países, ainda que seja garantida em todas as legislações; e o intercâmbio de informação praticamente não existe entre os países (ROJAS et al., 2006).

A América Central se encontra em uma etapa de modernização dos Sistemas de Avaliação de Impacto Ambiental, incluindo o fortalecimento tanto dos sistemas nacionais quanto regionais. No âmbito do Sistema de Integração Centro Americana (SICA), que funciona desde o ano 1993, cada país tem acordado seguir uma série de ações para alcançar a modernização, o que resulta essencialmente no desenvolvimento da AIA transfronteiriça com o fim de prevenir e mitigar os impactos de atividade nos projetos além das fronteiras nacionais (ROJAS et al., 2006).

Em 2002, os Ministros de Ambiente, no marco da Comissão Centro-Americana de Ambiente e Desenvolvimento (CCAD), assumiram o compromisso de elaborar um convênio regional sobre AIA de projetos, obras ou atividades transfronteiriças. Porém até o momento não se avançou na definição sobre qual instrumento será estabelecido de fato, restando ainda a possibilidade de adesão à Convenção de Espoo (ROJAS et al., 2006).

Porém, em 2004, depois de analisar novamente esta situação, as conclusões assinalaram a necessidade de estudar a fundo os instrumentos de harmonização regional em matéria de AIA, para adaptar o a AIA-T e avançar na discussão regional (CEDEÑO, 2008).

Um acordo de Impactos Transfronteiriços na América Central é um grande desafio, pois deveria gerenciar adequadamente tanto os impactos sobre os ecossistemas quanto os sociais, considerando que as comunidades que moram perto das fronteiras são as mais pobres da região. Esse acordo ajudaria a reduzir as tensões entre os estados no caso de desenvolvimento de megaprojetos que afetem a dois ou mais países. Ainda é importante resaltar que os governos constantemente mudam de ideologias, políticas, pessoal, entre outros, o que enfatiza a necessidade de dispor de um documento juridicamente vinculante para manter a ferramenta de AIA tanto em nível nacional quanto em nível transfronteiriço (CEDEÑO, 2008). 


\subsubsection{América do Sul}

Nas últimas décadas a América do Sul vive um processo de articulação e conformação de blocos regionais que permitem melhorar os processos comerciais na região e ingressar nas dinâmicas econômicas mundiais. Estes blocos funcionam paralelamente, afetando as dinâmicas fronteiriças, flexibilizando-as e desafiando a gestão ambiental em relação à sua capacidade de abordar os conflitos ambientais (GUDYNAS, 2007).

Contudo, os acordos ambientais que se seguem à formação de blocos comerciais são genéricos e as instâncias para dirimir disputas são ainda fracas ou focadas exclusivamente em questões comerciais, como se verifica em relação ao Mercado Comum do Sul. (MERCOSUL) O MERCOSUL ${ }^{4}$ tem lidado com questões conflituosas relacionadas a conflitos que não foram abordados adequadamente, apesar de contar com instrumentos de negociação focados no ambiente e um marco de referência (aprovado em 2001) na temática ambiental (GUDYNAS, 2007; QUEIROZ, 2005).

A Comunidade Andina de Nações $\left(\mathrm{CAN}^{5}\right)$ tem uma estratégia regional de biodiversidade para os países do trópico (aprovada em 2002). Esta se centraliza em atividades de integração e projetos e possui uma área ambiental que trata da missão fundamental de formular e desenvolver o seguimento das políticas públicas comunitárias. No entanto não se evidenciam ações concretas a respeito da AIA-T (CAN, 2012; GUDYNAS, 2007).

Apesar da melhora contínua nas ações de cooperação para realizar atividades em prol do desenvolvimento ambiental conjunto, ainda persiste a competição pelo uso dos recursos naturais, pelo melhoramento da competitividade comercial e o acesso aos melhores investimentos, além do uso de um conceito clássico de soberania, segundo o qual o país pode implementar qualquer projeto dentro de sua fronteira desde que

\footnotetext{
${ }^{4}$ MERCOSUL - Mercado Comum do Sul, nasceu formalmente em 1991 com a assinatura do tratado de Asunción pelos governos da Argentina, Brasil, Paraguai e Uruguai. O acordo considera que a "ampliação das atuais dimensões de seus mercados nacionais, através da integração, constitui condição fundamental para acelerar seus processos de desenvolvimento econômico com justiça social". Dentre os compromissos adquiridos para cumprir esse objetivo está a preservação do meio ambiente.

${ }^{5}$ CAN - Comunidade Andina de Nações. É uma comunidade de países unidos voluntariamente com o objetivo de alcançar um desenvolvimento integral, mais equilibrado e autônomo. Foi criada em 1969, através da assinatura do Acordo de Cartagena e formada pelos países da Bolívia, Colômbia, Equador e Peru.
} 
procure minimizar os impactos sobre os países vizinhos. Esta visão debilita os processos adequados de gestão ambiental (GUDYNAS, 2007).

Isto leva a um gerenciamento dos impactos ambientais fronteiriços através de acordos binacionais ou multinacionais, onde se mantém e respeitam as legislações sobre AIA internas. Existe uma colaboração mútua para atingir e gerir os impactos transfronteiriços e se trabalha na formação de acordos ou tratados para gerir conjuntamente os recursos compartilhados, como o caso do Estatuto do Rio Uruguai de 1975, o qual, segundo Pirillo (2011) é pioneiro em muitas das questões apresentadas na Convenção de Espoo, como a salvaguarda da vida humana, o aproveitamento das águas, a conservação dos recursos naturais, entre outros, onde os países prestaram mútua colaboração. Outro aspecto que se destaca é o Comitê Intergovernamental da Bacia do Rio da Prata, que foi criado no final da década de 1960 com o objetivo principal de promover o desenvolvimento sustentável da Bacia, além de gerir eventuais conflitos entre os países (PIRILLO, 2011; QUEIROZ, 2005; RIBEIRO, 2012).

Em termos gerais, os países membros do MERCOSUL possuem dispositivos legais suficientes para garantir uma efetiva conservação ambiental, especialmente a legislação brasileira que, a pesar de ter sido a pioneira em instituir a AIA, é a mais completa e moderna do MERCOSUL. No entanto, de forma geral, os países sulamericanos carecem de fiscalização eficaz para que as legislações sejam cumpridas, além de uma política de ação preventiva e repressiva dos governos por danos causados ao meio ambiente (ROCHA et al., 2005)

Os sistemas de AIA nos países sul-americanos mostram diferenças sobre sua cobertura, mecanismos de aplicação e gerenciamento. Apenas dois países (Paraguai e Bolívia) contemplam de maneira clara e explicita em suas legislações deveres a cumprir em relação aos efeitos transfronteiriços causados por projetos implantados em seus territórios (MERCOSUR et al., 2008).

As Avaliações de Impacto Ambiental convencionais que são aplicadas sobre empreendimentos binacionais ou em zonas de fronteiras devem ser redefinidas ampliando suas escalas, revisando seus procedimentos e melhorando substancialmente a consulta e informação pública. Devem ser complementadas com avaliações ambientais estratégicas setoriais, junto com avaliações territoriais mais amplas (OÑATE et al. $2002^{6}$ apud GUDYNAS,2007).

\footnotetext{
${ }^{6}$ OÑATE JJ, D PEREIRA, F SUAREZ, JJ RODRIGUEZ \& J CACHÓN (2002) Evaluación
} 
Em paralelo, deve-se reformar também o gerenciamento ambiental para passar a uma gestão integrada dos recursos naturais com um enfoque ecossistêmico mais amplo e fortalecido e uma melhor participação cidadã. Devido ao fato de que muitos dos problemas fronteiriços estão associados à implantação de grandes projetos de desenvolvimento, é necessário adotar uma perspectiva metodológica mais adequada e participativa, abordando de melhor maneira os complexos sistemas sociais e ambientais tensionados (GUDYNAS, 2007).

Outro mecanismo de integração é a União das Nações Sul-americanas $\left(\mathrm{UNASUL}^{7}\right.$ ), a qual congrega os 12 países sul-americanos. No contexto da UNASUL, encontra-se em andamento a Iniciativa para a Integração da Infraestrutura Regional SulAmericana (IIRSA), que pretende trabalhar principalmente no desenvolvimento dos transportes, energia e telecomunicações, com vistas a superar as barreiras geográficas regionais, fortalecer os mercados e promover oportunidades econômicas e de desenvolvimento sustentável da região (IIRSA, 2011a; UNASUR;CEPAL, 2011).

A iniciativa para a Integração da infraestrutura Regional Sul-americana (IIRSA) tem sua origem na reunião de presidentes da América do Sul, realizada na cidade de Brasília no ano 2000, quando foi adotado o "Plano de ação para a integração da infraestrutura sul-americana", proposto pelo Banco Interamericano de Desenvolvimento (BID) e a Corporação Andina de Fomento (CAF), com propostas para a ampliação e modernização da infraestrutura em um horizonte de 10 anos (UNASUR; CEPAL, 2011).

A IIRSA ordena sua intervenção em Eixos de Integração e Desenvolvimento (EID) e em Processos Setoriais de Integração (PSI). São dez EID os quais são articulados pela infraestrutura de transporte, energia e comunicações, cuja formação foi baseada nos fluxos de comércio (existentes e potenciais), e que delimitam espaços geográficos caracterizados por um tipo de riqueza em recursos naturais, biodiversidade, assentamentos humanos, áreas produtivas e serviços logísticos. O objetivo destes eixos

ambiental estratégica. Edicione MundiPrensa, Madrid. 382 pp.

${ }^{7}$ UNASUL - Criada pelos presidentes sul-americanos em 2008 como um espaço de articulação e dialogo político de alto nível que involucrou aos doze países da região. Seu objetivo é construir, de maneira participativa e consensual, um espaço de integração e união no âmbito cultural, social, econômico e político entre seus povos, outorgando prioridade ao diálogo político, as políticas sociais, a educação, a energia, a infraestrutura, o financiamento e o meio ambiente, entre outros, com alvo de eliminar a desigualdade socioeconômica, conseguir a inclusão social e a participação cidadã, fortalecer a democracia e reduzir as assimetrias no marco do fortalecimento da soberania e independência dos estados. (UNASUR; CEPAL, 2011) 
é principalmente desenvolver o comércio e criar cadeias produtivas conectadas com os mercados mundiais (BALVIN; PATRON, 2006; IIRSA, 2011a).

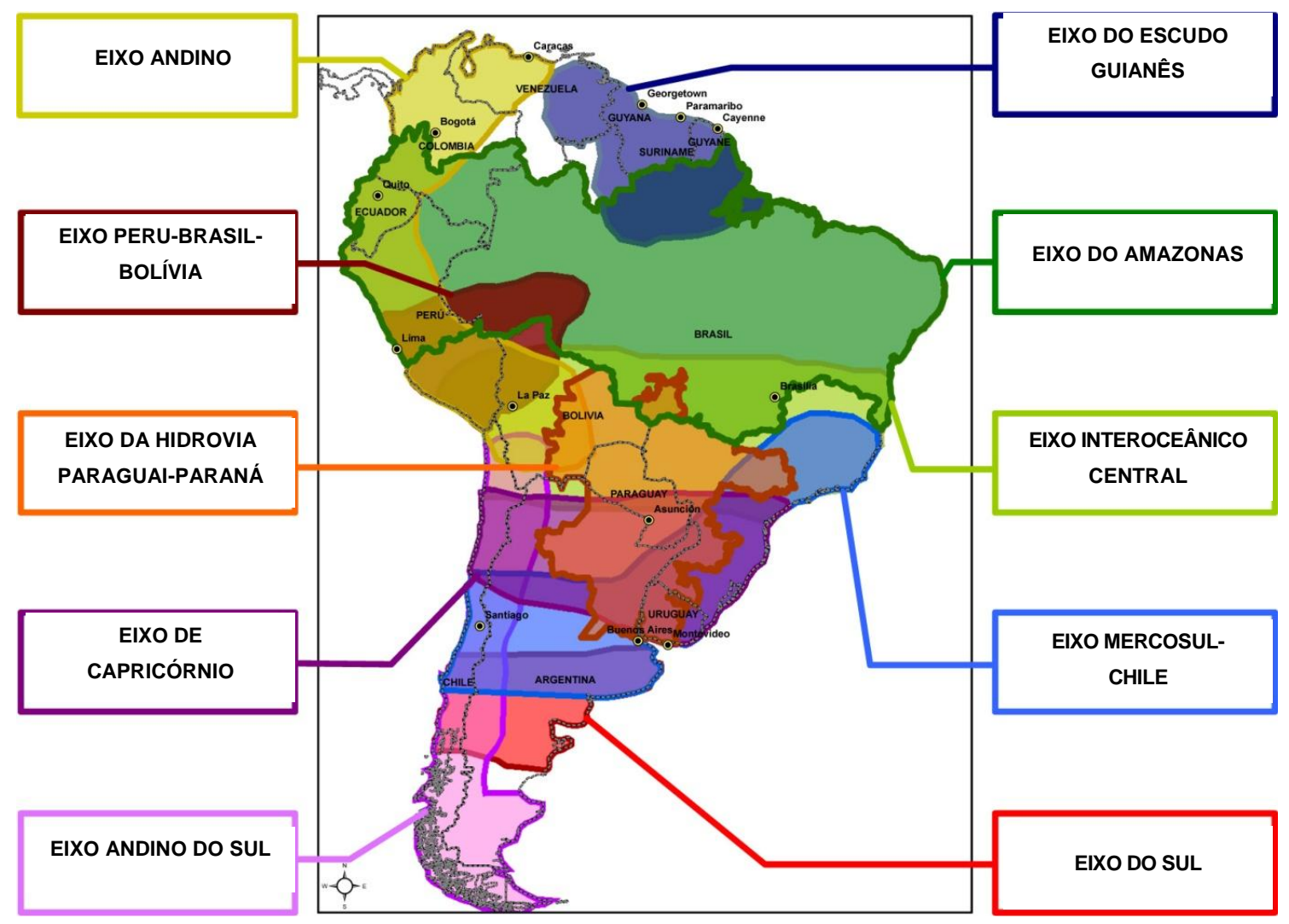

Figura 4 - Eixos de Integração e Desenvolvimento (EID) - IIRSA Fonte. GEOSUR (2014)

Por sua vez, os PSI procuram reduzir barreiras regulatórias, legais e operativas que limitam o uso da infraestrutura existente e as que obstaculizariam os investimentos em novos projetos para permitir o livre comércio de bens e serviços dentro da região. Assim, os PSI englobam tecnologias de informação e comunicações, sistemas operativos de transporte aéreo e multimodal, facilitação de travessias de fronteira, integração energética e instrumentos de financiamento (BALVIN; PATRON, 2006; IIRSA, 2011a).

Para atingir os possíveis impactos ambientais gerados pelas obras de infraestrutura que serão desenvolvidas, a CAF, no marco da IIRSA, desenvolveu a metodologia de Avaliação Ambiental e Social com Enfoque Estratégico (EASE), a qual tem como objetivo contribuir com o planejamento sustentável de infraestruturas através da aplicação de uma ferramenta consolidada que permita, tomando como escala de trabalho a área de influência dos grupos de projetos da IIRSA, identificar, com enfoque preventivo, as ações complementares em potencial, sob o ponto de vista socioambiental 
e cultural, quanto aos efeitos positivos dos projetos e à minimização de seus impactos negativos. (CAF, 2009) Segundo Madrid et al. (2011), no contexto do IIRSA, os países necessitam adequar suas estruturas legais, institucionais e operativas às capacidades de coordenação e monitoramento para conduzir processos efetivos de AAE, o que mostra que o panorama para a AIA-T nos países sul-americanos não é claro.

Como foi explorado anteriormente, cada vez é maior o alcance da AIA-T; temse popularizado, seus sistemas estão em diferentes etapas de desenvolvimento e são aplicados em diversas modalidades, desde instrumentos juridicamente vinculantes formalizados a acordos ad hoc (BASTMEIJER; KOIVUROVA, 2008b; CASSAR; BRUCH, 2003). Porém, há normas comuns nos enfoques gerais adotados pelos países e regiões: em todas as regiões, este marco geral esta definido pela convenção de Espoo, que é catalogada como a base e marco de referencia na AIA-T (BASTMEIJER; KOIVUROVA, 2008b).

Todos os países da União Europeia fazem parte da Convenção de Espoo e estes decidiram dar um enfoque mais doutrinal para sua aplicação que outras regiões, o que pode ser promissor, apropriado e eficaz para o desenvolvimento da AIA-T. Além disso, apesar de que o contexto europeu específico pode limitar a aplicação direta da Convenção de Espoo a outras regiões, suas experiências de implementação podem oferecer opções a respeito da aplicação dos elementos comuns da AIA-T em outras regiões (CASSAR; BRUCH, 2003; BASTMEIJER; KOIVUROVA, 2008b).

Outra consideração importante é que o marco jurídico da União Europeia e os instrumentos da UNECE estão relativamente avançados; nenhuma outra região tem um marco juridicamente vinculante em seu lugar (CASSAR; BRUCH, 2003), razão pela qual a União Europeia e sua aplicação da convenção de Espoo é um referente ao nível mundial para a AIA-T.

\subsection{AVALIAÇÃO AMBIENTAL TRANSFRONTEIRIÇA, CASO EUROPEU.}

O Convênio sobre a avaliação do impacto ambiental em um contexto transfronteiriço foi propiciado pelo ambiente político e social que antecedeu sua publicação. Assim, entre 1970 e 1980, foi vivenciada uma época de preocupação crescente com o meio ambiente nos âmbitos sociais e políticos, assim como o desejo 
cada vez maior de uma cooperação entre os países europeus, que resultou em importantes iniciativas tomadas no contexto internacional. Entre elas, cabe destacar:

- A conferência sobre o ambiente humano em Estocolmo (1972). Dentre os princípios desenvolvidos, destaca-se, neste contexto, o princípio 21: "Os estados têm a responsabilidade de assegurar que as atividades referentes à sua jurisdição ou controle não vão a causar dano ao ambiente de outros estados ou de áreas além dos limites nacionais".

- No acordo de proteção ambiental entre os países nórdicos (1974), foi estipulado que em todas as atividades ambientalmente perigosas que impliquem em uma perturbação significativa em outro estado contratante, o país de origem é obrigado a enviar toda a informação relevante para que o país receptor analise o potencial dano ambiental. É requerido que o país de origem faça uma AIA-T, e assim, o país receptor poderia iniciar as suas próprias investigações. Tais procedimentos marcaram uma fase embrionária dos procedimentos de AIA-T expressados em Espoo.

- $\mathrm{O}$ artigo $7^{\circ}$ da Diretiva Europeia 85/337/CEE estabeleceu, pela primeira vez na legislação europeia, disposições para os impactos transfronteiriços importantes. Porém, há poucas evidências de seu cumprimento.

- Em 1987, surgiu um importante instrumento legal relevante para o desenvolvimento da AIA-T: as metas e princípios da Avaliação de Impacto Ambiental (AIA), adotados pela UNEP (United Nations Environment Programme). O princípio 12 requer que se o processo de AIA nacional indica a probabilidade de ocorrência de um significativo impacto ambiental em outro país por uma atividade proposta, o país de origem deve notificar a o estado potencialmente afetado e transmitir qualquer informação relevante da AIA.

- Outro acontecimento de suma importância que ocorreu em abril deste mesmo ano foi a publicação do relatório da Comissão Mundial sobre o Ambiente e Desenvolvimento (Comissão Brundtland). Esta comissão recomendou aos governos que apoiassem o desenvolvimento de acordos de cooperação regional e sub-regional para a proteção e o uso 
sustentável dos ecossistemas transfronteiriços, através de programas de ação conjunta para combater os problemas comuns (CONNELLY, 1999; MARSDEN; KOIVUROVA, 2011).

Estes acontecimentos serviram de base para a discussão e documentação dos procedimentos estabelecidos na convenção de Espoo, que foi um dos primeiros instrumentos para a AIA-T, o qual forneceu um guia específico, claro, dinâmico e completo. A convenção tem três elementos inovadores: primeiro, dá mais detalhes sobre a notificação e consulta em relação aos impactos transfronteiriços, segundo, dá um significado mais preciso no direito internacional e terceiro, prevê a participação do público (BASTMEIJER; KOIVUROVA, 2008b).

Dois aspectos-chave para o cumprimento de Espoo são a efetiva cooperação e comunicação entre cada uma das partes, que é um dos compromissos expressos nos documentos do convênio: “As partes estão dispostas a melhorar a cooperação internacional em matéria de AIA - T"(COMISIÓN ECONÓMICA PARA EUROPA, 1991).

A convenção de Espoo toma força depois de sua regulamentação pela diretiva europeia sobre a AIA 97/11/EC, a qual, em seu Art. $7^{\circ}$, faz menção aos estados membros responsáveis pelo ajuste minucioso para cumprir o estipulado na convenção de ESPOO (MARSDEN; KOIVUROVA, 2011). Assim, as diretivas europeias cumpririam um papel importante, através do melhoramento contínuo e integração com a convenção de Aarthus - 1998. Acordo multilateral que procura garantir o acesso a informação, a justiça em matéria ambiental, mas, sobretudo, o fortalecimento da participação pública nos processos de tomada de decisão. Além do Protocolo de Kiev, que busca integrar a avaliação ambiental estratégica no contexto transfronteiriço. Também foram estabelecidas as seguintes diretivas que modificam ou trazem novos componentes para a AIA-T:

- 2001/42/EC - SEA, que trata de consultas transfronteiriças a respeito dos planos e programas que possam afetar os outros estados membros.

- 2003/35/EC. Nova emenda do processo transfronteiriço a respeito da participação pública.

- 2009/31/EC A emenda dos anexos 1 e 11 adiciona projetos relacionados à captura e armazenamento de $\mathrm{CO}_{2}$ (MARSDEN; KOIVUROVA, 2011). 
Desde a sua assinatura até hoje, a convenção de Espoo foi submetida a quatro avaliações de cumprimento e duas emendas; a primeira em 2001, na qual abre a convenção aos países que não fazem parte da UNECE, e a segunda em 2004, onde permite a participação da parte afetada no escopo, faz uma revisão das atividades do anexo 1 e exige avaliações de conformidade(UNECE, 2014).

Segundo a convenção de Espoo, quando existe a possibilidade da ocorrência de impactos ambientais transfronteiriços, as partes de origem e afetada devem agir da seguinte maneira (o procedimento é resumido na figura 5):

1. As partes deverão prevenir, reduzir e controlar o Impacto Ambiental transfronteiriço, e ainda adotar as medidas legais, administrativas ou de outra índole, para dar efeito ao convênio. Basicamente as AIA - T deverão ser realizadas na etapa de projeto da atividade proposta, e na medida em que procedam às partes, deverão tentar aplicar os princípios da AIA - T às políticas, planos e programas.

A aplicação da Convenção de Espoo dará inicio quando a atividade proposta esteja no apêndice 1 ou quando houver suspeita dos impactos transfronteiriços de uma atividade que não esteja especifica no apêndice Nesse caso, as partes interessadas serão consultadas e serão estas quem decidirão a aplicação ou não da convenção. No apêndice 3 da convenção, figuram diretrizes gerais para formular os critérios que permitam determinar quando se trata de um impacto de caráter prejudicial e magnitude apreciável.

As disposições do Espoo não afetarão o direito das partes em aplicar suas leis nacionais, regulamentos, disposições administrativas ou outras práticas jurídicas aceitas, com a finalidade de proteger a informação, cuja divulgação poderia atentar contra o segredo industrial e comercial ou contra a segurança nacional.

Não é afetado o direito de aplicar por meio de acordos bilaterais ou multilaterais, quando proceda, medidas mais rigorosas que as previstas no convênio. Tais disposições serão aplicadas sem prejuízo das obrigações em que as partes tenham contraído, conforme o direito internacional, no que diz respeito às atividade que tenham ou possam ter impacto transfronteiriço. 
A parte de origem deve garantir que o público das zonas passíveis de serem afetadas tenham a oportunidade de participar dos processos de AIA em iguais condições que seu próprio público

2. A parte de origem visará à realização de uma AIA, antes de tomar decisões ou de iniciar a execução de atividades que possam causar impacto ambiental transfronteiriço negativo e de magnitude apreciável e vigiará também para que as partes afetadas sejam efetivamente notificadas. Esta notificação deve ser feita o antes possível ou, como último prazo, quando o país de origem notifique a seu próprio público. A notificação deve compor-se de toda a informação acerca da atividade proposta, dos possíveis impactos transfronteiriços, a natureza da possível decisão e o prazo de resposta das partes afetadas para notificar seu interesse ou não de participar dos processos de AIA.

3. Em caso das partes afetadas não estarem interessadas em participar dos processos de AIA do país de origem ou se não responderem à notificação no prazo determinado, o país de origem pode continuar com seus processos de AIA nacionais; mas se as partes interessadas decidem participar do processo, então o país de origem deve enviar toda a informação pertinente de seu processo de AIA, incluindo os prazos para o recebimento de observações e a informação da atividade proposta e seus possíveis impactos ambientais transfronteiriços, se estes não foram enviados na notificação. A parte afetada deverá enviar toda a informação pertinente para a AIA que seja coletada em sua jurisdição; essa informação será proporcionada sem demora e quando seja oportuno através de um órgão misto.

Se existirem partes que creem ser afetadas pelo projeto, mas não foram notificadas, estas devem se reunir com as partes interessadas para intercambiar informação pertinente para decidir a existência ou não de impacto transfronteiriço. Em caso de não chegarem a um acordo, qualquer das partes pode apresentar o caso à comissão de investigação descrita no apêndice IV da convenção, a não ser que as partes decidam empregar outro meio para a solução da controvérsia.

As partes interessadas velarão para que o público das partes afetadas tenha acesso à informação sobre todo o processo, que tenha a 
oportunidade de colocar suas observações ou objeções e que estas sejam transmitidas efetivamente à parte de origem.

4. Preparação da documentação. A parte de origem prepara a documentação necessária para o processo de AIA que no mínimo deve ter, segundo o apêndice II da convenção, a descrição da atividade proposta, suas alternativas e sua finalidade, a descrição do meio ambiente que será afetado, do impacto ambiental e a avaliação de sua magnitude, as medidas para reduzir o impacto, a indicação dos métodos de predição, as hipóteses fundamentais e os dados pertinentes utilizados, os furos de conhecimento e as dúvidas surgidas ao coletar a informação, um esboço dos programas de supervisão e gestão, além de todo o plano de análise pós-projetos e um resumo não técnico.

Esta documentação deve ser enviada às partes afetadas através de uma comissão mista, se houver e as partes interessadas devem distribuir esta documentação às autoridades e público das partes afetadas, para que estas possam fazer as observações pertinentes, as quais devem chegar às autoridades competentes da parte de origem num prazo razoável antes da tomada de decisão.

5. Consultas baseadas na documentação para a AIA. A parte de origem consulta com as partes afetadas o possível impacto transfronteiriço e as medidas possíveis para sua gestão.

6. Decisão definitiva. As partes velarão para que a decisão definitiva tenha em conta os resultados do processos de AIA, as observações recebidas e os resultados das consultas realizadas. A parte de origem comunicará às partes afetadas a decisão definitiva e as razoes e considerações de fundamento.

Se uma das partes recebe informação nova sobre o impacto transfronteiriço não avaliado, deverá comunicar as partes interessadas antes da execução da proposta.

Quando uma das partes interessadas o solicite, serão celebradas consultas acerca da necessidade de revisar a decisão tomada.

7. Análise posterior do projeto. As partes interessadas determinarão a necessidade ou não de uma análise posterior ao projeto e, em caso afirmativo, em que medida será realizado. Se a análise chega à 
conclusão de que existe impacto transfronteiriço ou se descobriu fatores que podem causar o impacto, deverão informar imediatamente a outra parte; as partes interessadas celebrarão consultas para determinar as medidas para reduzir ou suprimir o impacto.

8. Programas de investigação. As partes prestarão especial atenção à institucionalização ou fortalecimento de programas concretos de investigação, focados na melhora dos processos de AIA e da gestão dos impactos ambientais.

9. Solução de controvérsias. Se existir controvérsia sobre a interpretação ou aplicação do convênio, as partes tentarão dar solução através de negociação direta ou de outros meios para a solução de controvérsias. Se não puder ser resolvido, poderá ser levado à Corte Internacional de Justiça (COMISIÓN ECONÓMICA PARA EUROPA, 1991).

$\mathrm{Na}$ figura 4 apresenta-se o esquema geral do procedimento de AIA - T proposto pela convenção de Espoo. 


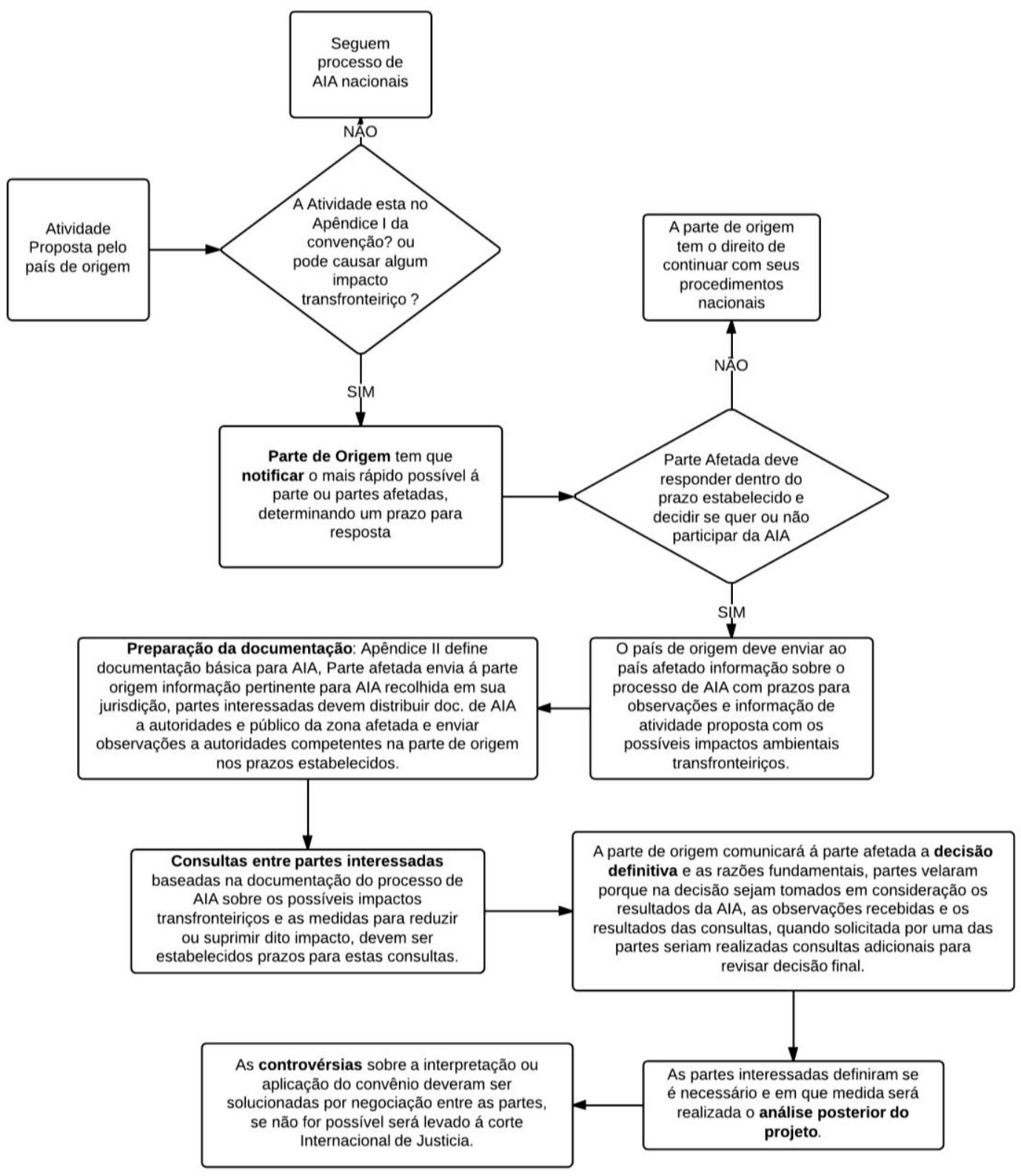

Figura 5 - Esquema processo geral AIA - T da convenção de ESPOO

Fonte: Construção própria baseada no Convênio sobre a avaliação de impacto ambiental num contexto transfronteiriço, Espoo (1991).

As diretivas europeias incluem, além do disposto na convenção de Espoo, medidas detalhadas para a implementação de todos os aspectos dos procedimentos de consulta transfronteiriça. O processo é colocado em funcionamento quando o país de origem identifica que o projeto proposto pode apresentar impactos ambientais transfronteiriços significativos, devendo-se então enviar toda a documentação com a descrição do projeto, os possíveis impactos e a natureza da decisão que será tomada, 
além de indicações sobre os períodos propícios para participação das partes interessadas (MARSDEN; KOIVUROVA, 2011).

\subsubsection{Aplicação da convenção de Espoo}

Os acordos bilaterais e multilaterais são elementos importantes na implementação e aplicação da Convenção de Espoo. A convenção estabeleceu o marco geral que regula os temas principais. No entanto, Boer (1999) considera que são necessários acordos entre os países envolvidos para desenvolver padrões de aplicação da AIA-T e assim garantir uma preparação cuidadosa evitando atrasos e atritos desnecessários.

A convenção é uma ferramenta útil para enfrentar os novos problemas ambientais transfronteiriços, de uma maneira cooperativa com pleno respeito ao meio ambiente e convertendo-se em um modelo para o desenvolvimento regional (CONNELLY, 1999)

$\mathrm{Na}$ aplicação da convenção ao longo de sua história, tem-se encontrado algumas dificuldades, como os diferentes tipos de governo (países centralizados e descentralizados), o idioma, a participação pública, a definição de quais são os impactos significativos, a falta de clareza nas responsabilidades, a divisão de custos, entre outros (ALBRECHT, 2008). Segundo Hildén e Furman (2001), isso pode ser devido ao abandono de algumas fases do procedimento de avaliação, às controvérsias entre os países, às diferenças de interesses, mas, sobretudo, a que a AIA é uma ideia compartilhada de maneira incompleta, uma vez que a ideia básica é compartilhada suficientemente, para que se tenha uma diretiva europeia sobre o tema; porém, as interpretações diferentes do que são as avaliações e de como elas estão relacionadas com outras atividades sociais, mostram que os detalhes desta ideia estão compartilhados de modo incompleto.

No entanto, a convenção tem sido aplicada com sucesso em muitos casos, e as dificuldades têm servido para melhorar a execução do processo. Um caso representativo, por sua complexidade e bom desenvolvimento, relaciona-se com a construção da linha de gás Nord Stream no Mar Báltico (figura 6), um empreendimento que envolveu nove países ao todo (sendo cinco simultaneamente países de origem e afetados, e quatro somente afetados). Além disso, entre os países envolvidos encontrava-se a Federação Russa, a qual não pertence à União Europeia, e apesar de ser 
signatária da Convenção de Espoo ainda não a ratificou, motivo pelo qual não estava legalmente obrigada nem pelo instrumento, nem pela diretiva europeia.

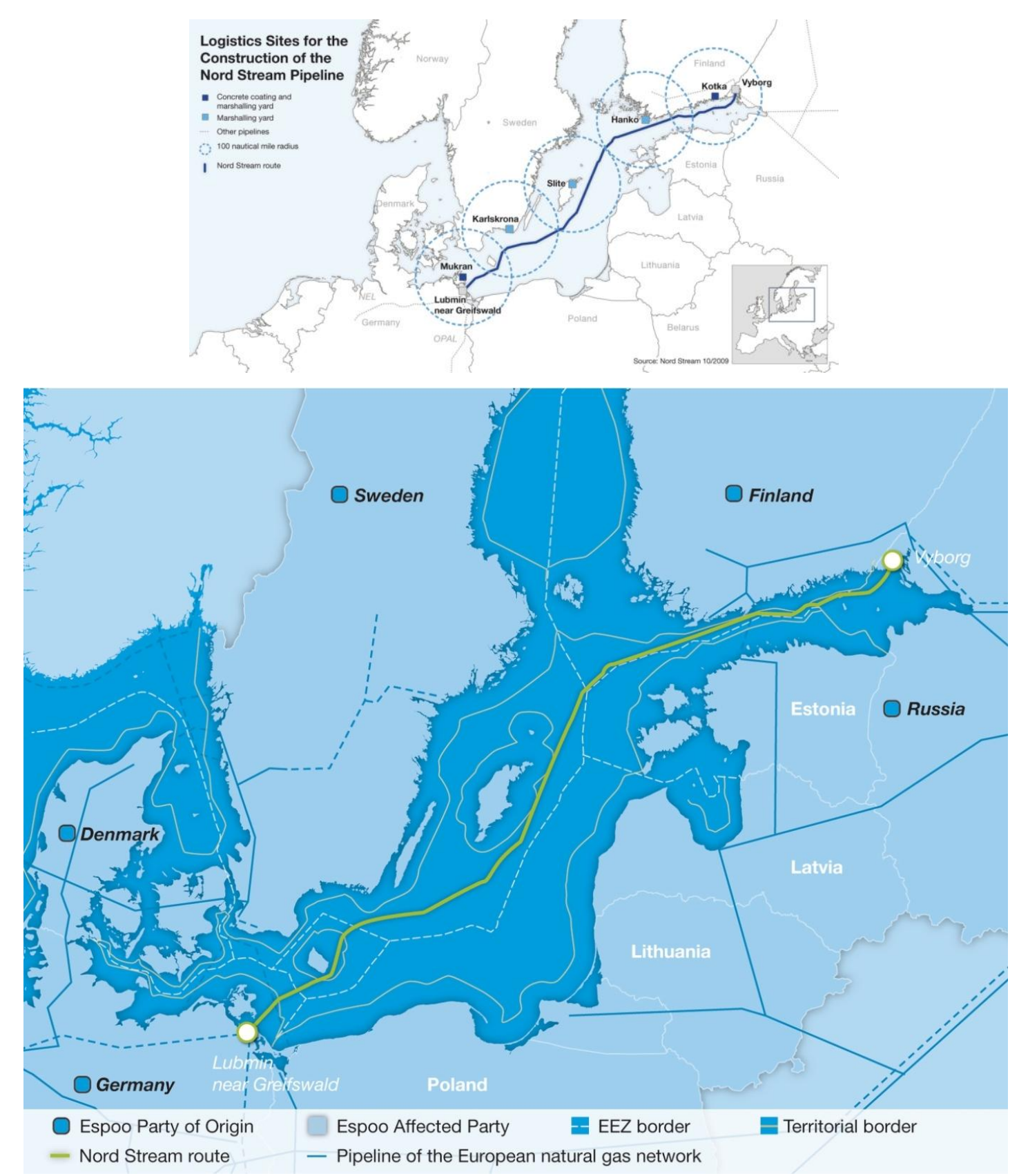

Figura 6 - linha de gás Nord Stream no mar Báltico

Fonte:NORD STREAM (2011)

Assim, no dia 19 de abril de 2006, os países que teriam seus territórios atravessados pela linha de gás obtiveram a concordância da Rússia em aplicar a convenção de Espoo na medida em que sua legislação o permitisse, o que permitiu definir também acordar todas as características básicas da AIA-T a serem conduzidas para o gasoduto. 
Em síntese, a AIA-T foi caracterizada pela formação de um comitê internacional formado por representantes de cada país, que cumpririam o papel de serem os pontos focais em cada um de seus países, sendo, portanto, um grupo-chave na coordenação de todo o processo.

Por haver processos de AIA nacionais tão diferentes, por conta da presença da Rússia, optou-se por realizar os cinco procedimentos de AIA nos países de origem (Dinamarca, Finlândia, Alemanha, Federação Russa e Suécia). Deste modo, cada uma das partes de origem abriria seus procedimentos nacionais de AIA aos outros oito estados e a seu público (KOIVUROVA; POLONEN, 2010).

A empresa responsável pelo empreendimento levou a cabo os cinco processos de AIA, de acordo com as normas de cada país. Cada um destes enviou uma notificação acerca dos possíveis impactos ambientais aos outros oito países afetados, e preparou ainda um documento de escopo, traduzido em todos os idiomas da região, que esteve à disposição do público dos nove países afetados para possíveis comentários, sendo realizado através dos pontos de contato dispostos em cada país (KOIVUROVA; POLONEN, 2010).

Cada um dos processos de AIA avaliou o trecho de gasoduto que correspondia à sua jurisdição, porém rapidamente se verificou que seria necessário avaliar os impactos ambientais da linha de gás em sua totalidade. Isso foi conseguido pelo comitê internacional, que foi o encarregado de coordenar a integração dos resultados obtidos em cada um dos processos de AIA nacionais, juntamente com as observações do público de cada país, para a realização da Declaração de Impacto Ambiental (Environmental Impact Statement - EIS), que passou a ser referida como "Informe de Espoo" (KOIVUROVA; POLONEN, 2010).

As reuniões da coordenação internacional foram realizadas durante todo o processo de AIA-T, com o objetivo de garantir que a empresa responsável elaborasse um Informe de Espoo para todo o gasoduto Nord Stream além da avaliação dos diferentes trechos já realizada por cada AIA nacional, assim como assegurar o cumprimento dos requisitos técnicos mínimos estabelecidos na Convenção de Espoo (KOIVUROVA; POLONEN, 2010).

A participação pública foi garantida por cada um dos países de origem desde o escopo, tanto de seu público quanto do público da parte afetada, segundo os mecanismos de participação dispostos em cada país. A empresa disponibilizou os documentos traduzidos em todos os idiomas envolvidos, para que estivessem à 
disposição do público dos nove países afetados, de tal modo que permitissem a recepção de comentários que eram levados aos pontos de contato para que fossem encaminhados ao comitê internacional para sua consideração. Os documentos mais importantes do escopo e o informe final também foram traduzidos para o inglês. A função mais importante das reuniões de coordenação internacional foi a criação de um fórum que permitiu receber comentários durante todo o processo, e sobretudo de expor o documento do escopo e o informe final, ao mesmo tempo, nos nove países afetados (KOIVUROVA; POLONEN, 2010).

As críticas realizadas à condução do processo de avaliação transfronteiriça foram relacionadas, principalmente, ao espaço restrito para a participação dos interessados. Como as reuniões eram restritas aos pontos de contato de cada país e por convite da empresa, não havia garantia suficiente da transparência do processo; há também o fato de as alternativas à implantação do gasoduto (tecnológicas e locacionais) não terem sido avaliadas exaustivamente, além de não se levar em conta os temas estratégicos (KOIVUROVA; POLONEN, 2010)

Destaca-se neste caso um bom exemplo de vontade política e de diálogo permanente entre os países envolvidos, aspectos muito importantes neste tipo de processo. Além dos aspectos normalmente envolvidos, os projetos cujos impactos ultrapassam fronteiras estão normalmente associados à ocorrência de efeitos cumulativos, ou ainda que em seus processos de AIA sejam geradas duplicações ou inconsistências. Essa é umas das razões pelas quais é necessária uma boa coordenação entre as partes envolvidas. O projeto da linha de gás Nord Stream demonstrou que com uma boa coordenação é possível desenvolver processos de AIA-T complexos com relativo sucesso.

Este caso pode ser considerado um dos mais representativos pelo seu grau de complexidade e por ultrapassar o paradigma estabelecido pela Convenção de Espoo. Em situações típicas, a parte de origem integra os impactos transfronteiriços, e as partes interessadas do país afetado a sua AIA nacional, com o objetivo de avaliar a área total do possível impacto. Antes do gasoduto de Nord Stream, não era claro como se daria a aplicação da Convenção de Espoo para esta tipologia de projetos, que atravessam e incluem vários países (KOIVUROVA; POLONEN, 2010). 
Segundo uma lista não oficial da $\mathrm{UNECE}^{8}$, até o ano 2011 tem-se realizado mais de duzentos casos de aplicação da convenção de Espoo. As revisões do cumprimento da convenção têm ressaltado tanto as dificuldades em sua aplicação quanto as estratégias para aumento de sua efetividade. Em relação a este aspecto, o trabalho de Hilden e Furman (2001) ressalta a importância da interação e retroalimentação regular entre os profissionais das zonas fronteiriças e as autoridades centrais, que representam os enlaces oficiais da convenção, para um ajuste contínuo da aplicação da convenção, de tal modo que coincida com a alteração da prática e da legislação de AIA, tanto no país de origem quanto no país afetado. Observa-se, também, a possibilidade de uma AIA conjunta, quando os países envolvidos são ao mesmo tempo o país de origem e o afetado, e seus processos de AIA estão harmonizados, como no caso dos países da União Europeia (HILDÉN; FURMAN, 2001).

Segundo Marsden (2011a), no relatório da revisão do cumprimento das diretivas de AIA em 2009, apoia-se uma maior sinergia entre a diretiva de AIA e a Convenção de Espoo, que inclui a simplificação dos requisitos atuais para projetos transfronteiriços. As diferenças entre processos de AIA nacionais sugerem a necessidade de uma maior harmonização, além do fato das barreiras de idioma serem uma preocupação constante, bem como a coordenação de procedimentos conjuntos ou individuais recomendados para projetos onde vários países são envolvidos. Por fim, o informe recomenda a reforma da legislação referente à definição dos prazos mínimos de consulta (MARSDEN, 2011a).

Na revisão de cumprimento da convenção de Espoo, no período compreendido entre 2006-2009, foi encontrado um aumento no número de vezes em que a convenção foi acionada, bem como o desenvolvimento contínuo da legislação nacional e acordos bilaterais e multilaterais para apoiar sua implementação. No entanto, também foram encontradas algumas dificuldades, que poderiam ser chamadas de pontos críticos, tais como:

- Estabelecimento de pontos de contato e suas funções, pontos de contato para notificação e pontos de contato para as questões administrativas.

- A participação pública, aspectos como a frequente falta de uma definição de "público", a falha em reconhecer que no artigo $3^{\circ}$, inciso

\footnotetext{
${ }^{8} \mathrm{http} / / /$ www.unece.org/fileadmin/DAM/env/eia/documents/database/Listing_of_transbou ndary_EIA_procedures_July_2011.pdf
} 
oitavo, e no artigo $4^{\circ}$, inciso segundo, as "partes interessadas" são responsáveis por garantir oportunidades para a participação pública.

- A falta de experiência na realização da análise de pós-projeto, que normalmente deixa de ser aplicada quando não é obrigatória. Para o período analisado havia somente um projeto piloto para um projeto de mineração, em que Belarus e Ucrânia concordaram em desenvolver um extensivo programa de monitoramento ambiental para assegurar uma implementação adequada e custo-efetiva do projeto, assim como procuraram melhorar as práticas de acesso às informações sobre os impactos ambientais transfronteiriços para o público dos países interessados.

- A necessidade contínua de acordos bilaterais ou multilaterais ou outros arranjos, para tratar particularmente das diferenças entre as partes no que se refere ao conteúdo da notificação, língua, prazos, como atuar quando não há uma resposta a uma notificação, ou se houver discordância sobre a necessidade de notificação, a interpretação de vários termos, e a exigência de análise pós-projeto (UNECE, 2009, 2013). 


\section{AVALIAÇÃO AMBIENTAL TRANSFRONTEIRIÇA NO CONTEXTO AMAZÔNICO.}

A América do Sul vive um momento histórico de integração: pela primeira vez tem-se observado resultados concretos das aspirações dos países sul-americanos de integração, materializando-se isso através da UNASUL e, especificamente, através do COSIPLAN $^{9}$ - IIRSA, o qual tem impulsionado a construção de projetos de infraestrutura nos âmbitos de transporte, energia e comunicação com o intuito de unir fisicamente a América do Sul. Neste âmbito de integração, é muito importante considerar os impactos ambientais transfronteiriços, mas sobretudo, deixar explícito como os países deverão atuar no caso da ocorrência deste tipo de impacto (CEPAL; UNASUR, 2011; PIRILLO, 2011).

A região Amazônica está composta por oito países, todos eles repúblicas democráticas - Bolívia, Colômbia, Equador, Guiana, Peru e Suriname são países unitários, ou seja, têm um só centro de poder político; por outro lado, Brasil e Venezuela são países federais, isto é, têm estados com políticas próprias e alto nível de autonomia. Estas questões cumprem um papel importante e devem estar presentes nos processos de AIA-T, pois estas diferenças de governo podem trazer dificuldades como a identificação dos pontos de contato entre os países (OTCA, 2014).

Somente três dos oito países amazônicos apresentam elementos normativos que consideram alguns pontos específicos da AIA-T (Anexo A). A Bolívia, por exemplo, aponta a obrigatoriedade em considerar os impactos ambientais transfronteiriços nos estudos de impacto ambiental (EIA) e a comunicação aos países vizinhos, quando houver acordos de reciprocidade, dos possíveis impactos ambientais transfronteiriços dos projetos planejados. Por sua vez, a legislação da Colômbia faz referência à comunicação aos países vizinhos dos possíveis impactos e da necessidade da prevenção. Bolívia e Brasil deixam explícitas as responsabilidades pelo gerenciamento e/ou desenvolvimento da AIA-T (BOLÍVIA, 1995; BRASIL, 2011; COLÔMBIA, 1974).

Geralmente, em todos os países, os Ministérios do Meio Ambiente e Relações Exteriores são os responsáveis pelo tratamento de assuntos ambientais de caráter internacional. Além disso, nas normativas de todos os países é refletido seu interesse pela preservação do meio ambiente, pela cooperação internacional e pelo cumprimento

\footnotetext{
${ }^{9}$ O Conselho Sul-Americano de Infraestrutura e planejamento da UNASUL foi criado por decisão do Conselho de Chefes e Chefas de Estado e de Governo em 10 de agosto de 2009.
} 
dos acordos internacionais assinados, tudo isso respeitando e defendendo a soberania de cada país.

No entanto, os grupos sub-regionais como a OTCA ou a própria UNASUR, que são os que abrangem a totalidade dos países amazônicos, deixam o campo aberto através de seus objetivos e políticas para que ocorra o desenvolvimento da AIA-T, como será visto na tabela 5. No caso da UNASUL, já existe uma proposta de metodologia para avaliação de impactos ambientais e sociais com enfoque estratégico (EASE), que avalia as carteiras de projetos da IIRSA, envolvendo avaliações do tipo transfronteiriço desde um nível estratégico, tentando avaliar o impacto no ambiente de todo o conjunto de projetos de uma maneira integral e não dividida por nações (CAF, 2010; COSIPLAN, 2012; OTCA, 2013; UNASUR; CEPAL, 2011)

Todos os países de amazônicos em geral tem normatividades explícitas para os processos de AIA, porém dentre seu arcabouço jurídico não têm normatividades, políticas ou acordos específicos para sinalar explicitamente os procedimentos a serem seguidos nos casos de impactos transfronteiriços, mesmo que todos os países promovam a cooperação internacional. Neste âmbito, trabalham para a solução conjunta de problemas específicos comuns como a mineração ilegal, o ordenamento da Bacia do Rio Amazonas, a conservação de ecossistemas compartilhados, o planejamento e gerenciamento de áreas protegidas, a proteção das minorias étnicas, principalmente dos povos indígenas ou na cooperação técnica para a geração de informações dos ecossistemas. Estas ações são desenvolvidas através de convênios binacionais ou multilaterais, ou através dos órgãos sub-regionais que trabalham na região, como a Organização do Tratado de Cooperação Amazônica (OTCA), a Comunidade Andina de Nações (CAN) e o Mercado Comum do Sul (MERCOSUL) (CAN, 2012; GTZ/FUNDECO/IE et al., 2001; MOLANO CRUZ, 2013).

A literatura consultada reporta a existência de vários acordos em temas ambientais como: Declaração de Princípios sobre os Bosques, Convenção sobre a Alteração Climática, Convenção sobre a Biodiversidade, Convenção sobre a Desertificação, entre outros. Além das declarações de Estocolmo de 1972 e do Rio de Janeiro de 1992, que oferecem bases importantes para a gestão dos impactos ambientais transfronteiriços, estas bases se encontram representadas nos princípios de cooperação, solidariedade e respeito pela soberania de outros países, pela participação cidadã, precaução, a proporção de informação pertinente e por notificação prévia e oportuna aos 
países que possam ser afetados por atividades que causem impactos ambientais transfronteiriços ( BASTMEIJER; KOIVUROVA, 2008b; TESLI; HUSBY, 1999).

Desta forma, observa-se que internacionalmente existem compromissos para garantir um gerenciamento adequado dos impactos transfronteiriços, pelo menos em nível de políticas e acordos, contudo, nota-se que a carência da comunicação entre os países, de maior observação dos acordos internacionais, de conciliação dos interesses, do fortalecimento dos mecanismos de participação cidadã, dos mecanismos de sanção e das capacidades de prosseguimento e fiscalização dos processos de AIA, dificultam o fortalecimento regional da institucionalização da AIA - T, com o intuito de desenvolver políticas que clarifiquem e concretizem os processos que devem ser seguidos (GUDYNAS, 2007; RHI-SAUSI; COLETTI, 2003).

Com o intuito de conhecer os processos quando os projetos desenvolvidos causam impactos ambientais transfronteiriços, desde a ótica dos agentes institucionais responsáveis em lidar com estes assuntos na prática, foi enviado um questionário aos escritórios encarregados destes assuntos nos oito países amazônicos, como descrito na metodologia, respondido somente por representantes da Colômbia e do Brasil.

Tabela 3- Respostas dos países ao questionário aplicado

\begin{tabular}{|c|c|}
\hline PERGUNTA & $\begin{array}{c}\text { Tem conhecimento de políticas, métodos ou estratégias nacionais } \\
\text { ou sub-regionais para o gerenciamento dos impactos ambientais } \\
\text { transfronteiriços? Quais? }\end{array}$ \\
\hline BRASIL $^{10}$ & $\begin{array}{c}\text { A rigor, o IBAMA é responsável pelo licenciamento de obras de impacto } \\
\text { transfronteiriços, uma vez que a norma que regula a competência para o } \\
\text { licenciamento ambiental é a Lei Complementar no } 140 / 2011 .\end{array}$ \\
\hline COLÔMBIA $^{\mathbf{1 1}}$. & $\begin{array}{l}\text { Atendendo as recomendações da convenção de Estocolmo 1972, é } \\
\text { proferido o Código de Recursos Naturais e proteção ao meio ambiente - } \\
\text { Decreto - lei } 2811 \text { de } 1974 . \\
\text { O compromisso ambiental também é assumido na Constituição política } \\
\text { de } 1991 \\
\text { Depois na convenção de Rio de Janeiro foram estabelecidos os princípios }\end{array}$ \\
\hline
\end{tabular}

${ }^{10} \mathrm{O}$ questionário foi enviado aos escritórios de Gerência de Políticas para o Licenciamento Ambiental e de Assessoria de Assuntos Internacionais do Ministério de Meio Ambiente, ao escritório da Diretoria de Licenciamento Ambiental do IBAMA e ao Sistema Eletrônico do Serviço de informação ao Cidadão - e-SIC; porém só foi obtida resposta deste último através da resposta à solicitação 07186/2013.

${ }^{11}$ Resposta ao questionário enviado via correio eletrônico ao Escritório de Assuntos Internacionais do Ministério de Ambiente e Desenvolvimento Sustentável da Colômbia. 


\begin{tabular}{|c|c|}
\hline & $\begin{array}{l}\text { 2, 17, } 18,19 \text { que estão relacionados com a prevenção do impacto ambiental } \\
\text { transfronteiriço; dois deles, o } 18 \text { e } 19 \text {, falam sobre a necessidade de } \\
\text { notificação aos países possivelmente afetados, porém a aplicação destes } \\
\text { princípios está restringida aos procedimentos no marco das relações } \\
\text { bilaterais entre países, ante a inexistência de um procedimento especifico. } \\
\text { Por fim, na lei } 99 \text { de } 1993 \text {, que cria o Ministério do Ambiente, são } \\
\text { abordados os princípios gerais da Declaração do Rio de Janeiro de 1992, } \\
\text { Convenção do Rio, entre eles a AIA, que é o instrumento básico para a } \\
\text { tomada de decisão por parte das autoridades ambientais a respeito de } \\
\text { atividades que possam causar dano significativo ao meio ambiente. Através } \\
\text { dela é cumprida a responsabilidade de vigiar que as atividades realizadas em } \\
\text { território nacional ou sob seu controle não causem impactos ambienteis em } \\
\text { países vizinhos ou em zonas fora de sua jurisdição. }\end{array}$ \\
\hline PERGUNTA & $\begin{array}{l}\text { Qual é o procedimento a seguir quando se apresentam impactos ambientais } \\
\text { transfronteiriços? }\end{array}$ \\
\hline BRASIL & $\begin{array}{l}\text { Destarte, via de regra, os empreendimentos transfronteiriços são } \\
\text { submetidos ao rito ordinário de licenciamento, podendo haver reuniões } \\
\text { técnicas convocadas pelos Ministérios das Relações Exteriores de ambos os } \\
\text { países. } \\
\text { O representante oficial do governo brasileiro nos assuntos relacionados } \\
\text { aos impactos transfronteiriços é o Ministério das Relações Exteriores do } \\
\text { Brasil - MRE. A Diretoria de Licenciamento envolve-se no âmbito técnico, } \\
\text { a convite do Itamaraty, essencialmente analisando os dados e subsidiando o } \\
\text { MRE nas negociações que envolvem impactos transfronteiriços e possíveis } \\
\text { negociações de medidas mitigatórias. }\end{array}$ \\
\hline COLÔMBIA & $\begin{array}{l}\text { Todos os projetos, obras ou atividades desenvolvidas em território } \\
\text { nacional, devem cumprir com a normatividade de licenciamento ambiental, } \\
\text { que busca prevenir a geração de impactos ambientais no país ou em países } \\
\text { vizinhos. } \\
\text { Porém, no caso de impacto ambiental transfronteiriço, para sua } \\
\text { verificação, análise e posterior resolução, são ativados os canais } \\
\text { diplomáticos, sendo as chancelarias dos países acompanhadas por suas } \\
\text { equipes técnicas, que tentam estabelecer a veracidade dos fatos e as } \\
\text { possíveis soluções. }\end{array}$ \\
\hline PERGUNTA & $\begin{array}{l}\text { Lembra de algum caso no qual tenha sido necessário o gerenciamento deste } \\
\text { tipo de impacto? Qual (is)? Que procedimento seguiu? }\end{array}$ \\
\hline BRASIL & $\begin{array}{l}\text { A maioria dos casos concretos de empreendimentos transfronteiriços são } \\
\text { pontes binacionais que, usualmente, não tem impactos ambientais } \\
\text { significativos, uma vez que encontram-se em áreas já antropizadas e } \\
\text { povoadas. } \\
\text { Em se tratando de processos licenciados pelo Ibama, pode-se consultar a } \\
\text { documentação,incluindo licenças, diretamente via internet }\end{array}$ \\
\hline COLÔMBIA & $\begin{array}{l}\text { Até a presente data, não se tem conhecimento de nenhum caso sobre } \\
\text { impacto ambiental transfronteiriço causado pela Colômbia a outros países; } \\
\text { porém, o Equador entrou com uma demanda ante a Corte Internacional da } \\
\text { Haya contra a Colômbia sob a pressuposição de afetações ambientais } \\
\text { geradas no marco do programa de erradicação de culturas ilícitas mediante o }\end{array}$ \\
\hline
\end{tabular}


herbicida glifosato, situação que é controvertida pelo governo colombiano.

Na seguinte tabela são descritos os objetivos, políticas e normativas dos órgãos sub-regionais atuantes na região, UNASUL, OTCA, CAN e MERCOSUL referentes ao meio ambiente, com o propósito de identificar como a atuação destes órgãos contribui ou não ao desenvolvimento da AIA - T.

Tabela 4 - Janela para o avanço da AIA - T no âmbito sub-regional

\section{Declaração de Cochabamba, 2006}

A UNASUL é considerada uma integração inovadora que incluía todas as realizações e os avanços dos processos do MERCOSUL e CAN, assim como a experiência do Chile, Guiana e Suriname, para além da convergência dos mesmos. O objetivo final deste processo de integração é o de favorecer um desenvolvimento mais equitativo, harmônico e integral da América do Sul.

Princípios reitores da integração sul-americana: [...]soberania, democracia e pluralismo.

$\underline{\text { Um dos objetivos da UNASUL é ter harmonia com a natureza }}$ para um desenvolvimento sustentável garantindo que as preocupações de caráter ambiental e as referidas às alterações climáticas, estejam presentes em todas as iniciativas de desenvolvimento regional,

UNASUL fundamentalmente nas obras de infraestrutura e energia, preservando o equilíbrio dos ecossistemas e a proteção da biodiversidade, com reconhecimento e valorização dos conhecimentos tradicionais.

Premissas para a construção da integração sul-americana.

O processo de construção desta integração é ambicioso e preciso em seus objetivos estratégicos e, ao mesmo tempo, flexível e gradual em sua implementação. Permite a todos serem parte, e ao mesmo tempo, possibilita que cada país assuma os compromissos segundo sua realidade. $\underline{\mathrm{O} \text { caminho mais adequado é o de avançar em }}$ políticas públicas comuns, respeitando os tempos e a soberania de cada país [...]

Objetivos da integração. [...] superação das assimetrias entre países, promover a conectividade da região, a partir da construção de redes de transporte e telecomunicações que interconectem os países, 


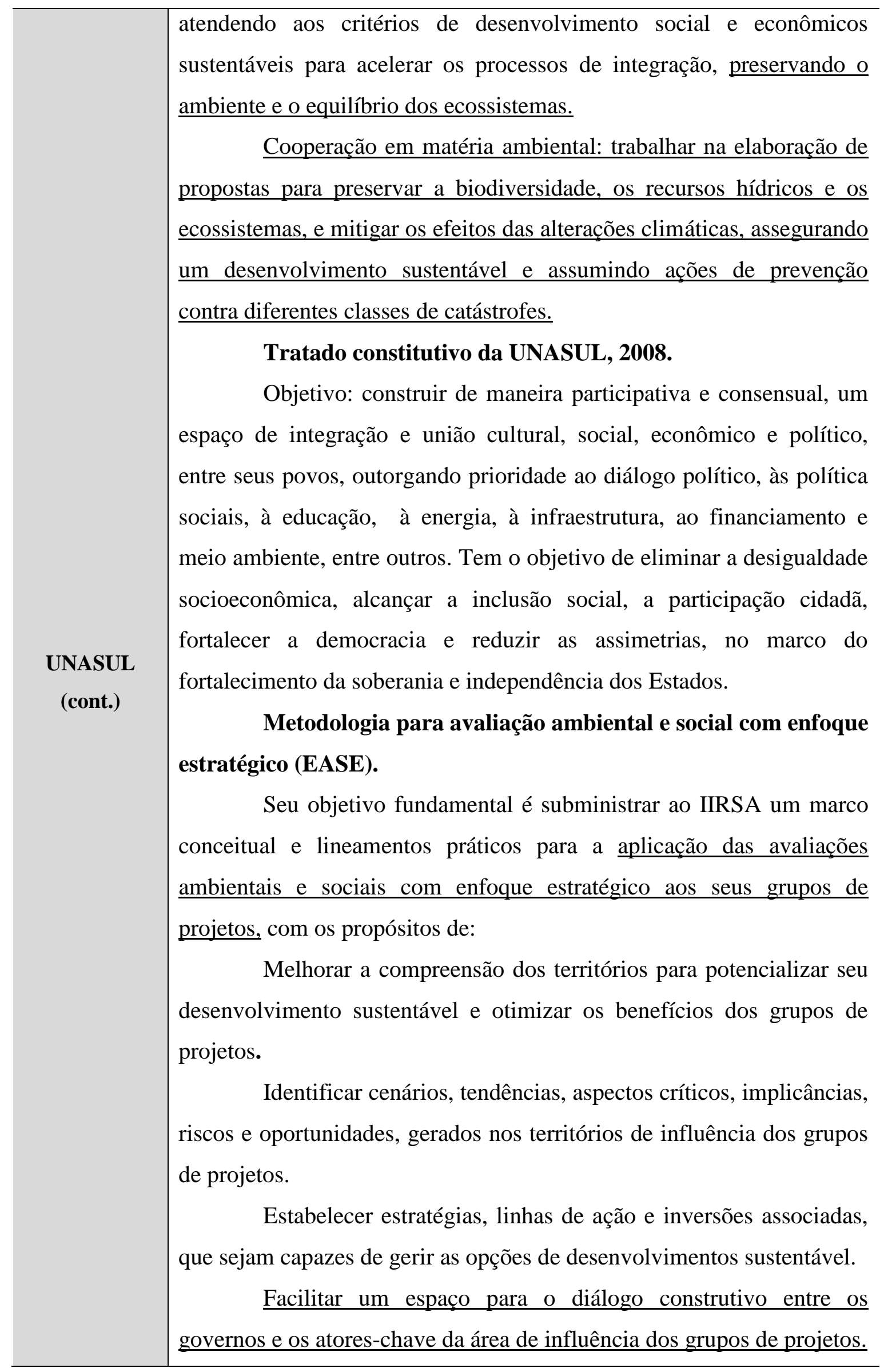


Agenda de projetos prioritários de integração (API), 2011.

Objetivo de promover a conectividade da região, a partir da construção e operação eficiente da infraestrutura, atendendo aos critérios de desenvolvimento social e econômico sustentável, preservando o ambiente e o equilíbrio dos ecossistemas.

\section{Declaração das ministras e ministros do COSIPLAN, 2011.}

Celebram a consolidação da Agenda de Projetos Prioritários de Integração (API), a qual reúne 31 projetos estruturantes para a integração sul-americana, com $o$ potencial de incentivar $o$ desenvolvimento socioeconômico regional. Aprovam, assim, a API, solicitando ao Comitê Coordenador do COSIPLAN, a sua avaliação permanente e os ajustes necessários, expressando o compromisso de atribuir especial atenção à implementação destes projetos com as ações necessárias, de caráter permanente, para mitigar seu impacto ambiental.

Plano de ação estratégico 2012 - 2022.

Ação 6.1. Aperfeiçoar, difundir e aplicar metodologias $e$ UNASUL (cont.) ferramentas de planejamentos territorial,[...] dentre estas, a Avaliação Ambiental e Social com enfoque estratégico (EASE).

Ação 6.1.1. Aplicação da EASE

Ação 6.1.3. Agenda Cartográfica. Para subsidiar o aperfeiçoamento do planejamento da infraestrutura regional, o COSIPLAN atuará na identificação geográfica de recursos naturais, das áreas de proteção ambiental e de reservas indígenas, das infraestruturas existentes e de outras dimensões, em escala adequada, na harmonização e na disponibilidade de mapas sul-americanos, o que também contribuirá para o aperfeiçoamento do sistema GEO SUL.

\section{IV reunião dos chefes de Estado da UNASUL, 2012.}

Declaram: 5. [...] Instruem ao secretário geral: iniciar com a devida prioridade e em coordenação com os conselhos setoriais pertinentes, um estudo sobre a disponibilidade e potencialidade dos recursos naturais na região sul-americana, com vistas no desenho de uma estratégia da UNASUL para seu aproveitamento. $\mathrm{O}$ mencionado 


\begin{tabular}{|c|c|}
\hline $\begin{array}{l}\text { UNASUL } \\
\text { (cont.) }\end{array}$ & $\begin{array}{l}\text { estudo contemplará entre outros aspectos, o levantamento e a } \\
\text { sistematização de informação relativa às reservas de recursos naturais, } \\
\text { assim como um mapeamento e inventário dos mesmos. } \\
\text { 41. Que a promoção do desenvolvimento sustentável, em suas } \\
\text { três dimensões: econômica, social e ambiental, com especial ênfase na } \\
\text { erradicação da pobreza e na preocupação pelos efeitos adversos das } \\
\text { alterações climáticas, tenha um caráter permanente no projeto de } \\
\text { integração sul-americana. }\end{array}$ \\
\hline OTCA & 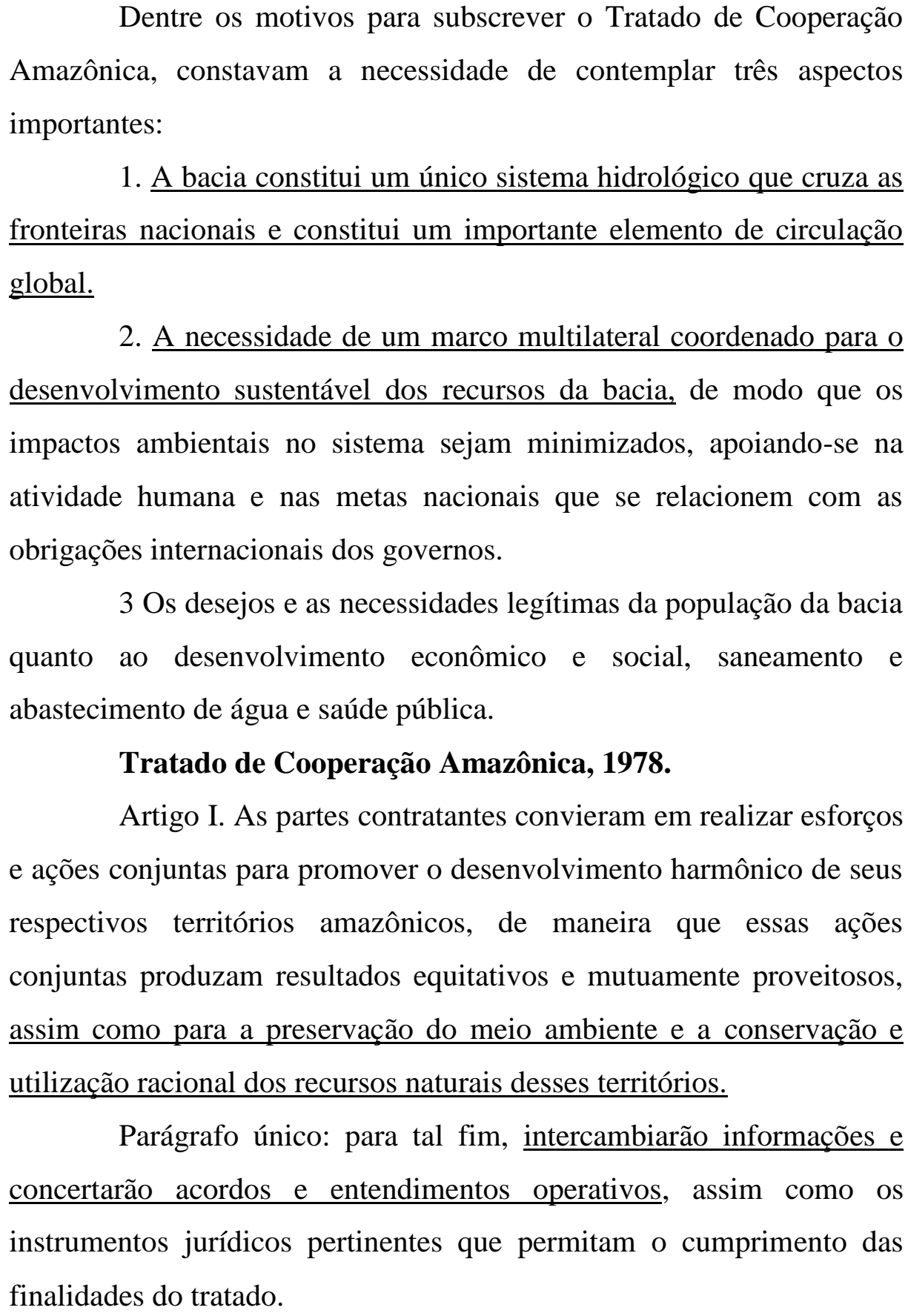 \\
\hline
\end{tabular}


Artigo XV. [...] se esforçarão em manter um intercâmbio permanente de informações e colaboração entre si e com os órgãos de cooperação latino-americanos, nas esferas de ação que se relacionam com as matérias que são objeto deste tratado.

\section{Objetivos estratégicos}

Facilitar o intercâmbio e a cooperação entre os países membros promovendo o desenvolvimento sustentável, e modos de vida sustentável com caráter estratégico na região, a fim de melhorar a qualidade de vida de seus habitantes, com ênfase nas populações vulneráveis, nos povos indígenas e em outras comunidades tribais.

Velar para que os interesses e a soberania dos países membros sejam respeitados e promovidos

Facilitar e fomentar ações que tendem à preservação, proteção, conservação e aproveitamento sustentável dos recursos amazônicos

Promover o aproveitamento dos recursos amazônicos dentro $\underline{\text { do respeito e harmonia com a natureza e o ambiente. }}$

\section{Declaração de San Francisco de Quito, 1989.}

Política Ambiental

Eles decidem criar a comissão especial de Meio Ambiente da Amazônia para que no exercício inerente à soberania de cada Estado sobre suas áreas amazônicas, se consiga, inter alia, açular as investigações ambientais para conhecer os riscos naturais atuais e potenciais na região, prevenir a deterioração dos recursos naturais amazônicos, particularmente o desmatamento e degradação dos solos, estudar metodologias comuns de AIA, elaborar programas e projetos, examinar ofertas de cooperação em aspectos relativos ao meio ambiente e analisar a possível compatibilização de legislações ambientais.

Coincidem em destacar a necessidade de estimular através da comissão de meio ambiente, a realização do inventário de recursos naturais e a análise da estrutura, função e dinâmica dos ecossistemas, para contribuir em assegurar os desenvolvimentos sustentáveis da bacia amazônica

Declaração de Iquitos, 2005. 


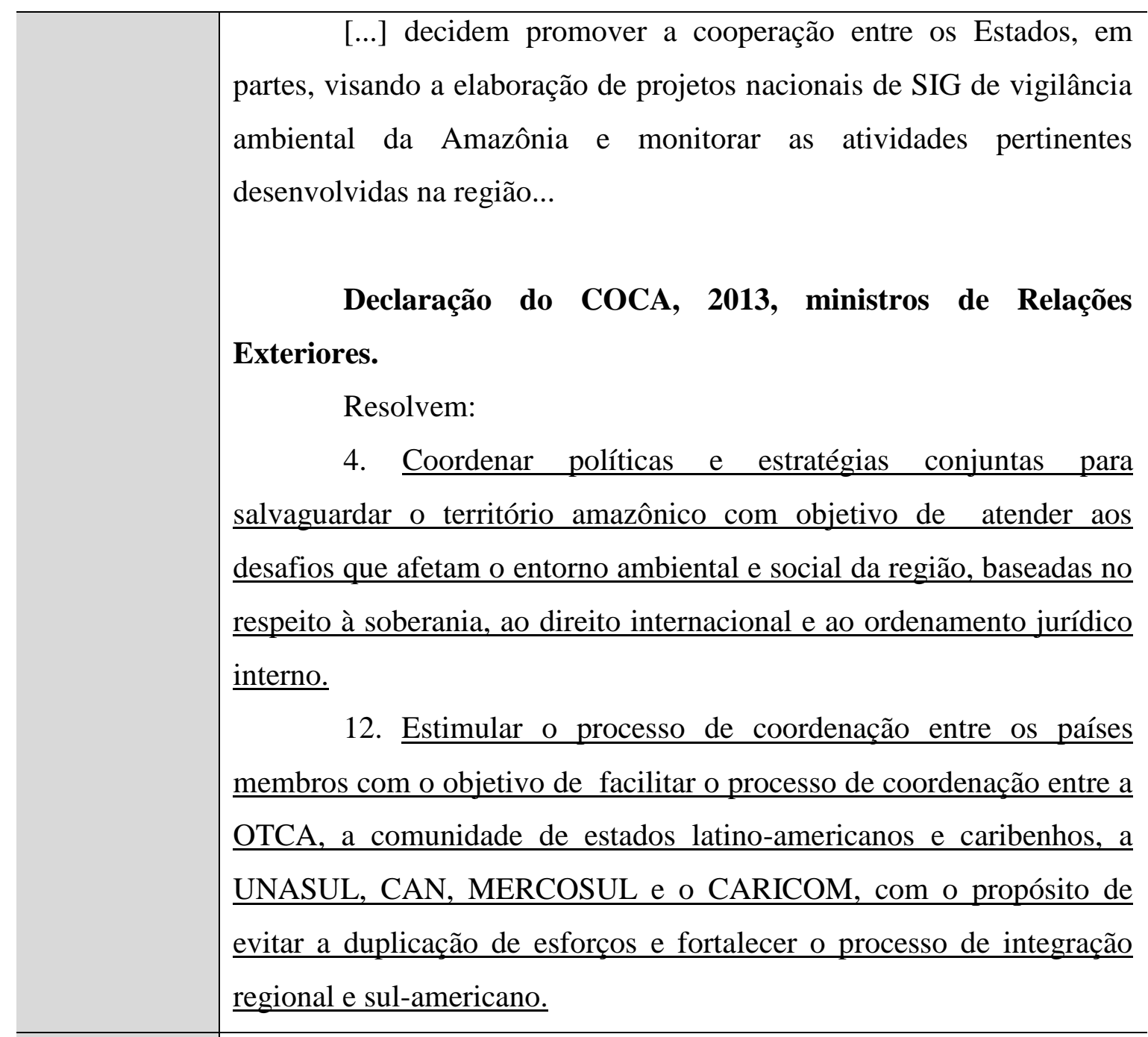

\section{Agenda Ambiental Andina 2012 - 2016.}

Objetivo: Orientar ações conjuntas para a coordenação de políticas e estratégias comunitárias, que contribuam com a melhora da gestão ambiental e com o desenvolvimento sustentável em harmonia com a natureza. Aprofundando o processo de integração e fortalecendo as capacidades nacionais e sub-regionais em matéria ambiental. CAN Enfatiza principalmente a biodiversidade, alterações climáticas e os recursos hídricos.

\section{Decisão 523}

Estabelece a Estratégia Regional de Biodiversidade para os países do Trópico Andino.

\section{Decisão 774}

Política Andina de Luta contra a Mineração Ilegal.

$\underline{\text { Dentre as políticas e discursos da CAN, encontrou-se como }}$ 


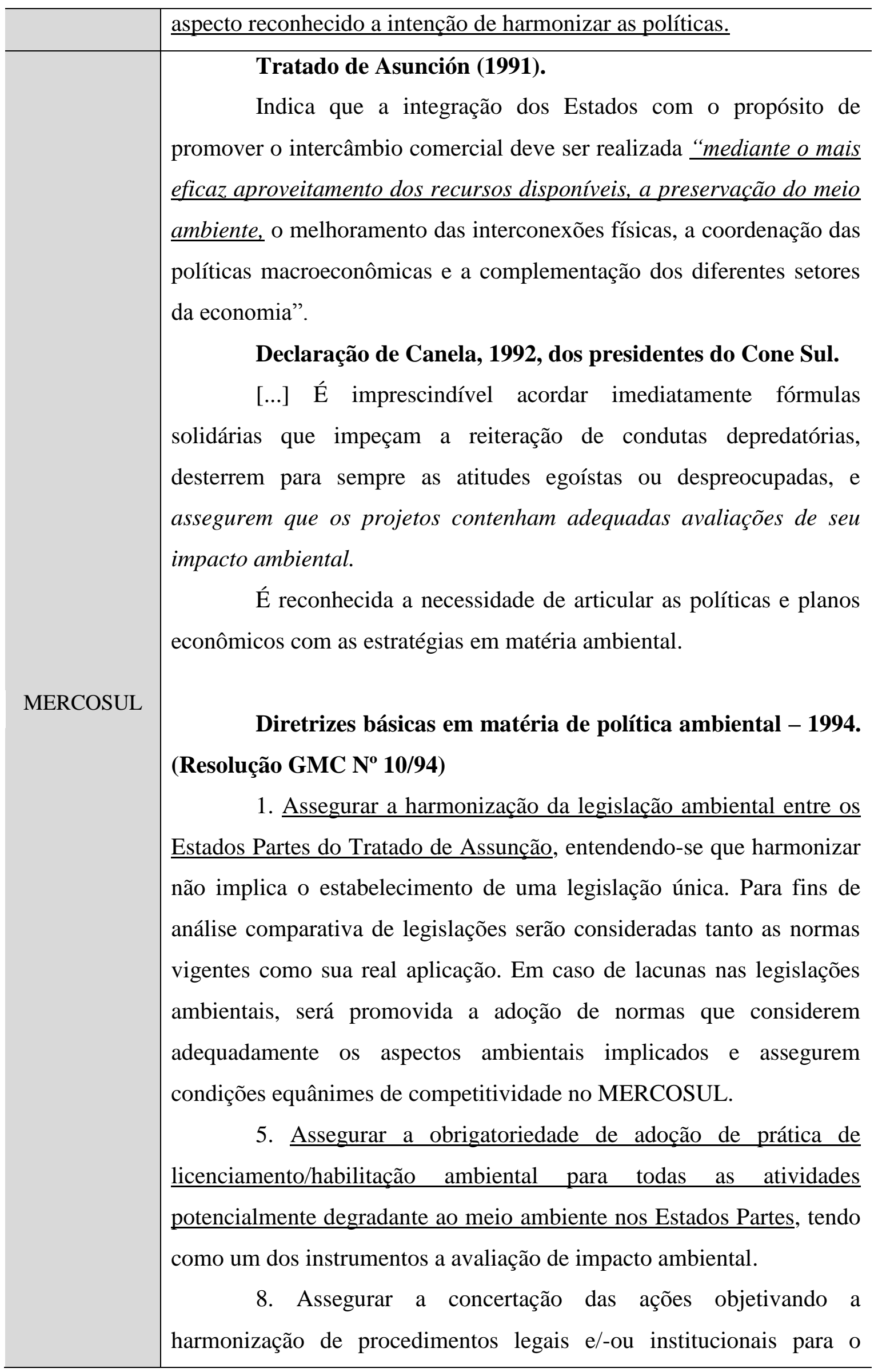


licenciamento/habilitação ambiental, e a realização dos respectivos monitoramentos das atividades que possam gerar impactos ambientais em ecossistemas compartilhados.

\section{Declaração de TARANCO - 1995, dos Ministros de Meio} Ambiente do MERCOSUL.

Reconhecem a necessidade de reforçar o marco institucional para tratamento da temática ambiental.

Intenção de harmonizar a legislação entre os países do MERCOSUL, entendendo que harmonizar não implica estabelecer uma legislação única, mas sim eliminar eventuais assimetrias e dirimir divergências.

\section{Acordo Marco sobre o Meio Ambiente do MERCOSUL -} 2001 (Decisão No 02/01)

Art. $1^{\circ}$ : Os Estados Partes reafirmam seu compromisso com os princípios da Declaração de Rio de Janeiro - 1992.

Art. $3^{\circ}:[\ldots]$ Orientar-se, inter alia, pelo seguinte:

Incorporação do componente ambiental nas políticas setoriais e inclusão das considerações ambientais nas tomadas de decisões que se adotem no MERCOSUL, para o fortalecimento da integração e para o fomento em internalizar os custos ambientais.

Art. 6 $6^{\circ}$ Os Estados Partes aprofundarão a análise dos problemas ambientais da sub-região com a participação dos organismos nacionais competentes e das organizações da sociedade civil, devendo implementar, entre outras, as seguintes ações:

Procurar a harmonização das legislações ambientais, considerando as diferentes realidades ambientais, sociais e econômicas dos países do MERCOSUL;

Estimular a harmonização das diretrizes legais e institucionais, com o objetivo de prevenir, controlar e mitigar os impactos ambientais nos Estados Partes, com especial referência às áreas fronteiriças;

Regulamento do Fundo para a Convergência Estrutural do 


\section{MERCOSUL}

Art. 37 - Meio ambiente

Um projeto unicamente será elegível se otimiza a utilização dos recursos naturais e prevê ações de mitigação dos danos ambientais provocados por ele em sua área de influência direta.

\section{Capitulo V Execução dos Projetos}

Art. 54 - Responsabilidades do Estado Parte em que é executado o projeto.

As ações derivadas do desenvolvimento e execução dos projetos em um ou vários dos Estados Partes serão de responsabilidade exclusiva dos mesmos.

O Estado Parte beneficiário do projeto aprovado pelo CMC deverá:

Observar e fazer cumprir a normativa nacional em matéria de regulação econômica, laboral, ambiental e social, assim como em matéria de contratação, auditorias e controles nacionais exigidos.

Fonte: CAN (2012); COSIPLAN (2011, 2012); IIRSA (2011b); MERCOSUR (2001, 2006, 2009); MERCOSUR et al. (2008); OTCA (2004, 2010, 2013); UNASUR $(2006,2010,2012)-$ elaboração propria, os grifos são nossos.

Nos objetivos e políticas dos órgãos sub-regionais existem compromissos de sustentabilidade, proteção ambiental, manutenção do equilíbrio ecossistêmico, compartilhamento de informação, reconhecimento da necessidade de articular as políticas e planos econômicos com as estratégias em matéria ambiental; e em todos os órgãos sub-regionais existe a recorrente intenção de harmonização de políticas e/ou legislação ambiental (tabela 5). A OTCA, por outro lado, surge ante a necessidade de fomentar um desenvolvimento sustentável da bacia do Rio Amazonas e, diferentemente dos outros órgãos sub-regionais atuantes na região, não tem intenções comerciais, mas, principalmente, objetiva um desenvolvimento sustentável da região (OTCA, 2012a).

De acordo com estes compromissos, todos os blocos têm desenvolvido e estão desenvolvendo projetos interessantes de cooperação, como o gerenciamento integrado e sustentável dos recursos hídricos transfronteiriços da bacia do rio Amazonas, bases de dados diagnósticas da Amazônia, sistemas de informação compartilhados e a estratégia regional para a conservação da biodiversidade da CAN. Neste marco foi feita uma 
análise dos sistemas de AIA dos países que a conformam, sendo igualmente realizada uma análise sobre os sistemas de AIA com a perspectiva de harmonizar as políticas ambientais no MERCOSUL, os desenvolvimentos dos projetos de SIG, EASE, em nível regional na UNASUL, entre outros (COSIPLAN, 2012; GTZ/FUNDECO/IE et al., 2001; OTCA, 2010, 2012a, 2012b; RHI-SAUSI; COLETTI, 2003; ROCHA et al., 2005).

Todos estes processos de cooperação, entre eles, o compartilhamento da informação e o trabalho conjunto em geral, contribuem significativamente para facilitar o panorama da realização das AIA-T, pois estão preenchendo lacunas, como a dificuldade de identificar os pontos de contato nos outros países quando se faz a notificação inicial, a geração de bases de dados diagnósticas que possam ser usadas nos processos de AIA, facilidade para o compartilhamento de informação entre países, a incompatibilidade dos sistemas nacionais de AIA e participação pública que causam problemas na aplicação da AIA-T em nível mundial, como foi exposto no Marco Teórico.

Não obstante, faltam ações concretas neste caminho, apesar de existirem iniciativas como a EASE. Tanto os países sul-americanos, quanto os órgãos subregionais atuantes carecem ainda de um conjunto claro de requisitos jurídicos, processuais e institucionais, sobre como conduzir, analisar e finalizar a AIA - T, que segundo a prática em nível mundial, é um fator determinante nestes processos, como visto na tabela 1 .

Além dos aspectos mencionados, ainda há vários obstáculos a serem ultrapassados, conforme apontam os estudos dos sistemas de AIA feitos nos marcos da CAN e o MERCOSUL. Apesar das intenções de harmonização das legislações ambientais, ainda falta um longo caminho a percorrer (ROCHA et al., 2005). No entanto, existem muitas intenções expressas nos fóruns de debate sobre o assunto, mas sem produzir, efetivamente, avanços nesta área, pois como afirmam seus críticos, não passam de intenções cuja efetividade e resultados estão sujeitos a conveniências conjunturais de caráter adverso. Significa dizer que as propostas de harmonização não refletem as assimetrias existentes entre os diferentes países, o que dificulta, e muito, o estabelecimento de uma regulamentação harmonizada. (OTCA, 2012b; QUEIROZ, 2005).

Desde a perspectiva da valorização de impactos dos megaprojetos de infraestrutura, foi ressaltado desde o marco da estratégia regional de biodiversidade da 
CAN, a necessidade de avançar nos processos de integração da gestão ambiental dos megaprojetos de desenvolvimentos. Foi identificada como limitante a diferença de escalas na avaliação dos impactos ambientais nos megaprojetos. Enquanto alguns deles têm uma escala espacial de manifestação regional, ou seja, incluem toda a América do Sul, na temática dos ecossistemas transfronteiriços é gerenciada uma escala diferente e com expressão espacial menor (GTZ/FUNDECO/IE, 2002).

Além disso, encontrou-se a inexistência de um bom nível de interação entre as dependências das instituições públicas que gerenciam os temas de biodiversidade, com as que direcionam os temas de desenvolvimento, ou seja, falta comunicação, situação recorrente em todas as escalas, o que dificulta os processos de AIA - T. Os temas ambientais são considerados como aspectos contrários ao desenvolvimento, com excesso de burocracia, o que faz com que sejam considerados problemáticos, impedindo, muitas vezes, o êxito em sua realização. A capacidade das grandes empresas de lobby sobre as autoridades é uma ameaça para aplicar ou manter a normativa, assim como a probabilidade de desregularização e de colapso dos sistemas de licenciamento prévio de megaprojetos e pela falta de um sistema de informação aberto. Porém, também foram encontradas certas potencialidades, como a influência das agências financiadoras no desenvolvimento de estudos ambientais e a consideração dos aspectos econômicos dos recursos naturais nos estudos de impacto ambiental, que tem sido crucial na tomada de decisões sobre projetos de explorações florestais em ecossistemas fronteiriços (GTZ/FUNDECO/IE, 2002; IIRSA, 2010a, 2011a; UNASUR; OLADE, 2012).

No caso da UNASUR e dos megaprojetos de infraestrutura com propósitos de integração, como no caso da IIRSA, há uma certa coordenação entre os países. No entanto, a avaliação dos impactos ambientais é de responsabilidade de cada país, e não tem, como visto anteriormente nos países em questão, guias ou normativas específicas que delimitem o caminho no caso de encontrar impactos transfronteiriços (MERCOSUR et al., 2008). Este processo tem apresentado sérias críticas, especialmente porque esta iniciativa encerra um processo de integração física com ênfase na integração econômica, porém, a melhora e o cuidado dos aspectos sociais e ambientais não são variáveis priorizadas (BALVIN; PATRON, 2006; DIDOB, 2010; PERZ et al., 2013; RODRIGUEZ ARAQUE, 2013).

No âmbito da UNASUL, na IV reunião de chefes de Estado em 2012, instruíram o Secretário Geral da UNASUL a iniciar um estudo sobre a disponibilidade e 
potencialidade dos recursos naturais na região, com o propósito de estabelecer uma estratégia de aproveitamento. Além disso, em 2008 foi subscrito um convênio de integração energética entre Brasil e Peru, o que indica que a exploração de recursos naturais continua e cada vez é mais forte (DOUROJEANNI, 2006; MARC DOUROJEANNI et al., 2009). Essa situação justifica a urgente necessidade de avançar na construção de marcos normativos internacionais que permitam realizar a AIA - T e que apoiem efetivamente a tomada de decisões(PERZ et al., 2013; WWF et al., 2009).

A falta de esse marco jurídico dificulta as negociações e o alcance dos compromissos, favorecendo a discricionariedade nas medidas adotadas por cada país (WWF et al., 2009).

Já tem sido identificada por meio dos órgãos sub-regionais a necessidade de trabalhar nesta direção; por exemplo, MERCOSUL (2008) destaca como insumo para a elaboração de critérios comuns, que o MERCOSUL poderia tratar nos projetos de infraestrutura de integração regional, elementos comuns e consensuais das AIA na prática de cada país e a promoção de AAE (MERCOSUR et al., 2008).

Por outro lado, a OTCA ao perceber que a IIRSA resulta no principal instrumento de planificação dos processos de integração física na Amazônia, percebe-se que vários dos eixos de integração, seus projetos e os projetos que cada país prioriza, incumbem a Amazônia. A mesma define seu papel como coadjuvante em seu desenvolvimento, alentando o cumprimento de adequados protocolos de avaliação e mitigação de impactos ambientais de acordo com as normas nacionais respectivas e os compromissos internacionais adquiridos pelos países membros, que evitem comprometer a sustentabilidade ambiental do entorno regional (OTCA, 2004). 


\section{APLICAÇÃO DA AIA - T NO CONTEXTO AMAZÔNICO. ESTUDOS DE CASO.}

Como visto no capítulo anterior, a AIA - T nos países amazônicos não está estruturada, não se tem acordos regionais específicos que obriguem aos países a realizarem AIA - T, mesmo que, cada país tenha políticas nas quais promulgam o compromisso pelo respeito aos acordos internacionais assinados e a promoção da cooperação internacional.

Entre os acordos internacionais assinados por todos os países amazônicos, estão o Estocolmo 1972 e Rio 1992, onde são estabelecidos os princípios-chave da AIA

- T. Como consequência, estes países teriam o compromisso de fazerem este tipo de avaliação. Porém, a AIA - T não é uma prática comum nestes países.

A seguir, são apresentados dois casos que servem para ilustrar esta situação e é descrita a metodologia EASE da IIRSA e suas aplicações como uma tentativa de incluir os impactos ambientais transfronteiriços nos megaprojetos da IIRSA desde um foco estratégico.

\subsection{Complexo Hidrelétrico do Rio Madeira.}

O rio Madeira é o segundo rio mais caudaloso da bacia Amazônica, superado apenas pelo rio Amazonas. O rio drena uma das regiões mais biodiversas do planeta e faz fronteira entre Bolívia e Brasil. Aporta água da cordilheira dos Andes e contribui com $35 \%$ dos sedimentos que fluem até o rio Amazonas. Nasce da união dos rios Beni e Mamoré na Bolívia, e flui até o norte seguindo a fronteira entre Brasil e Bolívia, para ingressar em território brasileiro, cruzando os estados de Rondônia e Amazonas, sua bacia hidrográfica abarca os territórios da Bolívia, Peru e Brasil (figura 7). Com a riqueza de sedimentos e nutrientes que aportam as águas da região, estima-se que a zona do rio Madeira é uma das áreas mais biologicamente diversas de toda a bacia Amazônica (AIDA, 2009; MEGO, 2008). 


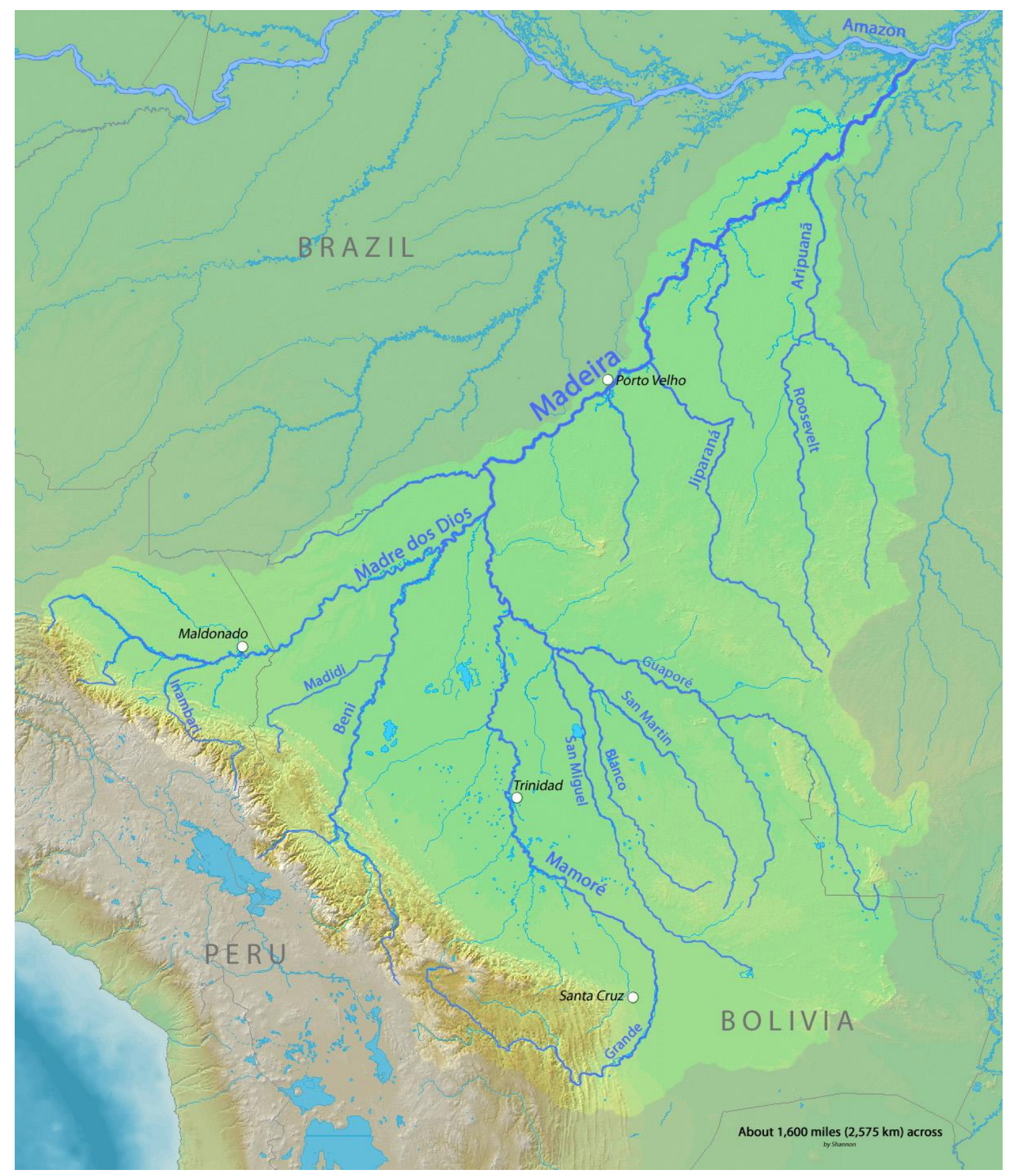

Figura 7 - Bacia Hidrográfica do Rio Madeira Fonte. SHANNON (2010)

O complexo hidrelétrico do Rio Madeira é um dos projetos prioritários do eixo Peru - Brasil - Bolívia da Iniciativa para a integração da Infraestrutura Regional SulAmericana (IIRSA). Conformado por quatro hidrelétricas, as de Santo Antonio e Jirau, em território brasileiro, com capacidade instalada de 6450MW. A primeira localizada a 7 km a montante de Porto Velho (capital de estado de Rondônia), a segunda a 190 km da fronteira entre Brasil e Bolívia, a terceira binacional Brasil/Bolívia no rio Guaporé na fronteira entre estes dois países e a quarta em território boliviano, Cachuela Esperanza, 
situada no rio Beni (Figura 8). Além das hidrelétricas que estão contempladas, há redes de linhas de transmissão para a conexão com a rede nacional integrada no Brasil, além da extensão da hidrovia a montante de Porto Velho, e uma rede de hidrovias que é estendida pelos territórios da Bolívia e do Peru, através dos rios Madeira, Guaporé, Mamoré, Beni e Madre de Dios (AIDA, 2009; EULER; SANTOS, 2009; FURNAS et al., 2007a).

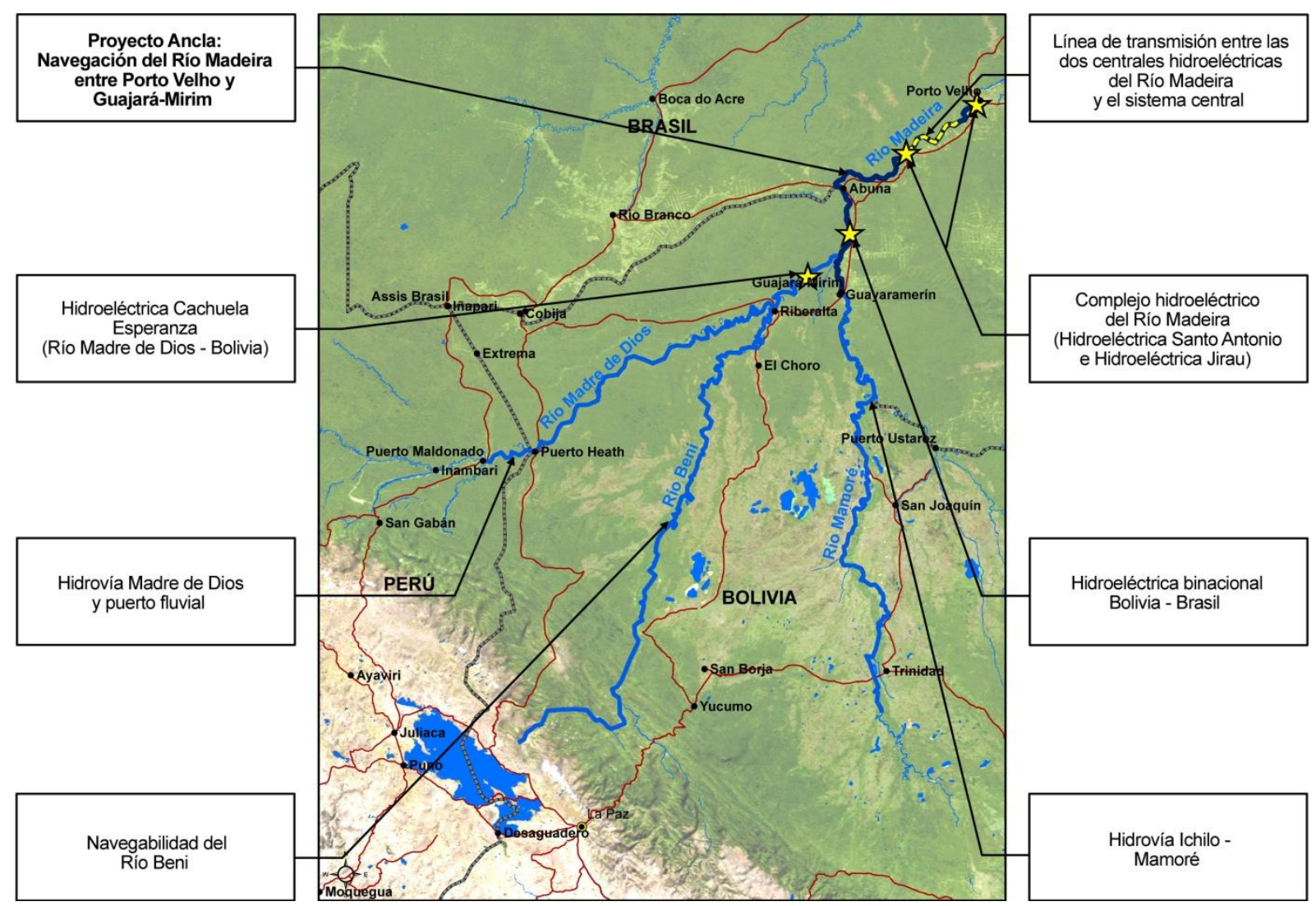

Figura 8 - Localização das hidrelétricas que formam o Complexo do rio Madeira Fonte. GEOSUR (2014b)

Em 2004, a construtora Odebrecht solicitou ao governo boliviano uma permissão para realizar estudos de viabilidade para a construção das hidrelétricas no território deste país, porém, o governo boliviano havia promulgado o Decreto Supremo 28389, que declara de interesse e prioridade nacional a definição de uma política nacional em matéria de aproveitamento integral das bacias hidrográficas do país, e suspende temporariamente o tratamento de solicitações e a concessão de todo tipo de 
licenças para usinas hidroelétricas. Em consequência a solicitação foi negada em $2006^{12}$. ( AIDA, 2009; BOLIVIA, 2005; FOBOMADE; CGIAB, 2007; MEGO, 2008)

Ante esta negativa, o governo brasileiro decidiu continuar com a construção das usinas hidrelétricas em seu território. Assim, em meio às polêmicas e tensões entre os governos do Brasil e Bolívia, por conta dos possíveis impactos transfronteiriços destas usinas e pelas grandes incertezas decorrentes dos projetos, foram licenciadas as usinas de UHE Santo Antonio que está em construção, e a UHE de Jirau que foi inaugurada em 2012 (MEGO, 2008).

Segundo estudos independentes e oficiais tanto brasileiros quanto bolivianos, existe uma grande possibilidade de que a Bolívia possa sofrer inundações devido à acumulação de sedimentos na extremidade superior do reservatório de Jirau, que elevariam os níveis de água no trecho do rio imediatamente a montante do reservatório, sendo também previstos outros impactos ambientais como:

$\checkmark$ Graves impactos na ictiofauna e recursos pesqueiros, como o caso do bloqueio da migração dos bagres do rio Madeira, especialmente da dourada (Brachyplatatystoma rouxeauxii) e piramutaba (B. vaillantii) que sustentam pescadores na Bolívia, Brasil e no Peru;

$\checkmark$ Devido à mineração na zona, os sedimentos são ricos em mercúrio, e o alagamento disponibiliza mecanismos necessários para que este possa ser liberado e convertido em metil-mercúrio, uma forma muito tóxica do mercúrio,

$\checkmark$ Desmatamento da floresta Amazônica,

$\checkmark$ Outros impactos sociais, como a perda de terras para culturas devido às enchentes, deslocamento e/ou extinção cultural de comunidades indígenas isoladas, extinção da pesca comercial, chegada de pescadores e garimpeiros brasileiros deslocados por conta das represas, destruição das condições locais para construção de obras de autoabastecimento de energia elétrica, bem como a proliferação dos vetores da malária (AMIGOS DA TERRA; INTERNATIONAL RIVERS NETWORK, 2006; BRASIL; IBAMA, 2007; COBRAPE, 2006; FEARNSIDE, 2014;

\footnotetext{
${ }^{12}$ Segundo o Observatori del Deute en la Globalització (ODG), 2010 A solicitação foi rejeitada pela Superintendência baseada nos questionamento sociais e ambientais emitidos por diferentes instituições bolivianas.
} 
FOBOMADE; CGIAB, 2007; ISAKSSON; STORBJÖRK, 2012; MEGO, 2008; WWF et al., 2009).

O processo de licenciamento destes projetos foi caracterizado pela pressão política, irregularidades em seu processo, mecanismos de informação e participação inadequados, falta de comunicação entre o governo e a sociedade e por gerar grandes polêmicas tanto no Brasil quanto em nível internacional (AIDA, 2009; COBRAPE, 2006; EULER; SANTOS, 2009; MEGO, 2008).

As principais críticas foram feitas pela qualidade do Estudo de Impacto Ambiental (EIA) apresentado por Furnas/Odebrecht, onde se encontraram várias incertezas, falta de profundidade no estudo e não avaliação das diferentes alternativas. Este continha ainda afirmações, como, por exemplo, de que os projetos não iriam causar impactos ambientais em outros países, sem que houvesse estudos necessários para assegurá-lo, mas, sobretudo, foi fortemente criticada a abrangência, pois desde os termos de referência feitos pelo IBAMA e consequentemente no estudo, as avaliações focaram só nos impactos ambientais na bacia do rio Madeira correspondente ao Brasil, excluindo totalmente dos estudos e da participação pública a Bolívia e o Peru, que também fazem parte da bacia. Pelo que, fora importante fazer acordos multilaterais para incluir a estes países no processo de AIA brasileiro (AMIGOS DA TERRA; INTERNATIONAL RIVERS NETWORK, 2006; BRASIL; CONAMA, 1986; BRASIL; IBAMA, 2007;COBRAPE, 2006; CONAMA, 2007; FEARNSIDE, 2014; FOBOMADE; CGIAB, 2007; FURNAS et al., 2007a, 2007b, 2007c;TUCCI, 2007; WWF et al., 2009).

O próprio IBAMA, em seu parecer $\mathrm{N}^{\circ} 14$ (2007, p. 220), assinala que

[...] A bacia do rio Madeira cobre cerca de um quarto da Amazônia brasileira e sua contribuição para o fluxo dos rios bolivianos é da magnitude de 95\% (precisamente, em sua bacia estão todas as vias navegáveis e as cidades mais importantes da Bolívia). Após drenar toda a parte leste da Bolívia, norte e oeste do estado de Rondônia e sul do estado do Amazonas, em um percurso de aproximadamente $1.450 \mathrm{~km}$, deságua na margem direita do rio Amazonas, $27 \mathrm{~km}$ a montante de Itacoatiara. Cerca de $50 \%$ da drenagem do Madeira corre na Bolívia, 10\% no Peru e $40 \%$ no Brasil. Isso significa que as alterações neste ambiente 
são sempre significativas e potencialmente geradoras de desequilíbrios transfronteiriços".

E ainda conclui que:

[...]dado o elevado grau de incerteza envolvido no processo, a identificação de áreas afetadas não contempladas no Estudo, o não dimensionamento de vários impactos com a ausência de medidas mitigadoras e de controle ambiental necessárias à garantia do bem-estar das populações e uso sustentável dos recursos naturais, e a necessária observância do Princípio da Precaução, a equipe técnica concluiu não ser possível atestar a viabilidade ambiental dos aproveitamentos Hidrelétricos Santo Antônio e Jirau, sendo imperiosa a realização de novo Estudo de Impacto Ambiental, mais abrangente, tanto em território nacional como em territórios transfronteiriços, incluindo a realização de novas audiências públicas. Portanto, recomenda-se a não emissão da Licença Prévia (BRASIL; IBAMA, 2007).

No entanto, devido à importância do projeto para o Plano Acelerado de crescimento do Brasil (PAC), tanto o Ministério de Meio Ambiente quanto o IBAMA sofreram fortes pressões para licenciar o projeto, pelo qual depois deste parecer a junta diretiva do IBAMA foi substituída em abril de 2007. Seus novos membros baseados em estudos adicionais, concederam a licença previa três meses depois, e as licenças de operação foram concedidas em 2008 e 2009, apesar das objeções contínuas da equipe técnica do IBAMA (EULER; SANTOS, 2009; FEARNSIDE, 2014; FRANCO NETO; OLIVEIRA AOKI, DE, 2009; MEGO, 2008;TUCCI, 2007).

A partir da ampla mobilização da sociedade civil e de organizações camponesas, indígenas e ambientalistas da Bolívia e do Brasil, em novembro de 2006 o ministro de Relações Exteriores da Bolívia apresentou oficialmente ao seu homólogo no Brasil a preocupação do governo boliviano pela construção das hidrelétricas e os potencias impactos ambientais e sociais sobre seu território, solicitando informações detalhadas sobre o processo, reuniões formais para tratar o assunto e lembrando a assinatura de diversos instrumentos internacionais para a proteção, conservação, investigação, navegação, uso racional, intercâmbio de informação e fiscalização dos 
recursos amazônicos, especialmente em áreas fronteiriças, além do convênio binacional para a preservação, conservação e fiscalização dos recursos naturais, assinado em 1990 (FOBOMADE; CGIAB, 2007; ODG; CÁTEDRA UNESCO DE SOSTENIBILITAT, 2010).

Perante tais afirmações, o governo brasileiro aceitou se reunir com a Bolívia, e em dezembro de 2006, os ministros acordaram a formação de um grupo binacional de trabalho sobre o projeto e criaram uma comissão mista para falar sobre o assunto. Porém, em meados de 2009, a comissão interinstitucional interrompeu seu funcionamento, considerando como resultado final o fato da delegação governamental brasileira reconhecer a possibilidade da ocorrência de impactos em território boliviano e a aceitação da necessidade de revisar a curva guia, que é um dos temas de conflito e que poderiam supor alagamentos na Bolívia. Um dos elementos que coloca fim ao funcionamento da comissão, foi a impossibilidade de realizar maiores contribuições, além da denúncia e alerta, pois todo o processo de negociação bilateral estava enquadrado na "agenda positiva" entre Bolívia e Brasil, uma agenda conciliadora que considera outros temas energéticos. Esta apresenta premência nos níveis de decisão máximos do governo e elimina qualquer possibilidade de uma posição firme de rejeição por parte da diplomacia e do governo boliviano (FOBOMADE; CGIAB, 2007; RIBERA ARISMENDI, 2010; SANT’ANNA, 2012).

A Bolívia está submetida a uma dupla tensão, uma por conta do debate interno sobre continuar uma tendência de desenvolvimento capitalista, explorando ao máximo seus recursos naturais ou a preservação do meio ambiente, procurando um modelo de desenvolvimento local e uma integração territorial alternativa. A outra tensão é a complexidade das relações assimétricas entre Brasil e Bolívia, uma vez que o Brasil representa um apoio importante à economia boliviana, em consequência, o governo boliviano prefere seguir mantendo boas relações políticas e econômicas com seu vizinho. Tais razões fazem parte dos impedimentos para que a Bolívia tome medidas mais drásticas, como levar o caso às cortes internacionais, o que de fato, deveria ter sido feito (GAMBOA; GUDYNAS, 2013; FOBOMADE; CGIAB, 2007; ODG; CÁTEDRA UNESCO DE SOSTENIBILITAT, 2010; SANT’ANNA, 2012).

Não obstante, a plena vontade do Brasil em se reunir com a Bolívia foi mais como um ato mais de protocolo e estratégia para gerenciar diplomaticamente o assunto; o Brasil não deu marcha ré em sua pressa para construir as hidrelétricas. Foram escutadas expressões como: "Não cabe um acordo com a Bolívia ... na medida em que 
as duas hidrelétricas estão no território do Brasil...”, por parte do ex-ministro de Minas e Energia do Brasil, Silas Rondeau. Ou ainda, a "Bolívia tem que provar que haverão impactos em seu território...", desconhecendo o princípio 21 expressado em Estocolmo, onde se deixa claro que qualquer país é livre para explorar seus recursos naturais sem causar dano aos países vizinhos, e o princípio de Precaução, expressado na convenção da biodiversidade, no qual é estabelecido que a falta de evidência científica não justifica a não tomada de medidas quando existe uma ameaça de dano ambiental, uma vez que o governo brasileiro é quem deve provar que não haverão impactos na Bolívia (MEGO, 2008)

De igual modo, são desconhecidos conceitos como "interesses comuns" dos países ribeirinhos ou de "soberania territorial limitada", sobre os recursos hídricos compartilhados, no caso do uso das águas internacionais, como é o caso de rio Madeira, colocando em perigo os recursos naturais e a população do país vizinho (FOBOMADE; CGIAB, 2007).

Além das ações políticas tomadas pelo governo boliviano, a associação da defesa etnoambiental Kanindé denunciou o governo brasileiro ante o Tribunal Latinoamericano da Água, o qual reconheceu que a AIA do projeto não considerou os impactos nos povos indígenas e que tem um potencial conflito transfronteiriço por causa das represas. O tribunal, baseado no convênio 169 da OIT, através do princípio 10 da declaração de Rio 92, sobre o meio ambiente e desenvolvimento e da Constituição Federal Brasileira, resolveu "censurar" o governo do Brasil e recomendar que o governo cancele as licenças e efetue novos estudos antes de continuar com estes projetos. Foi também censurado pelo Fórum Mundial da Água, realizado em Istambul, devido aos prejuízos para a vida de populações indígenas, alteração de ciclos fluviais e da biodiversidade. Os projetos, porém, continuaram adiante (AIDA, 2009; BERMANN et al., 2010).

Como consequência da fraqueza do governo boliviano, que não tomou as medidas suficientes para barrar a obra, até que foram avaliados e considerados todos os impactos em seu país, atualmente são sofridas as consequências. Não só os territórios da Bolívia foram inundados de maneira inusual, mas também encontrou-se $o$ desaparecimento de peixes, o que levou a população boliviana a cobrar seu presidente por não ter feito o necessário no momento oportuno, além do pedido de explicações ao Brasil. O Brasil, por sua vez, aceitou avaliar em conjunto os impactos gerados e sua relação com as hidrelétricas (CRAIDE, 2014; RITTNER; BORGES, 2014a, 2014b). 
A Justiça Federal determinou no dia 10/03/2014 que os consórcios Santo Antônio Energia e Energia Sustentável do Brasil, responsáveis pela construção das hidrelétricas do Rio Madeira, em Porto Velho (RO), refaçam o Estudo de Impacto Ambiental (EIA) e o Relatório de Impacto Ambiental (RIMA), considerando todos os impactos decorrentes da vazão e volume histórico do maior afluente do Rio Amazonas (MACHADO, 2014).

\subsection{Rodovia Interoceânica}

A rodovia binacional Brasil - Peru é localizada na região do MAP, tri fronteira Peru (Madre de Dios) - Brasil (Acre) - Bolívia (Pando). No Brasil é denominada como BR 364 e BR 317 e no Peru como "carretera Interoceánica", que passa pela fronteira com a Bolívia, abarcando assim os três países (Figura 9). O seu propósito é o de integrar o sudeste amazônico a uma economia mundial, proporcionando pontos de venda de exportação através dos portos do Atlântico no sul do Brasil, assim como nos portos do Pacífico no Peru. Faz parte da IIRSA e é considerada como um projeto-chave no eixo Peru-Brasil-Bolívia (BALVIN; PATRON, 2006; BRAVO ORELLANA, 2013; ECOLOGIA et al., 2008; INTERSUR CONCESIONES S.A., 2007; PERZ et al., 2011, 2013; RIBERA, 2011;WALSH; CONSECIONARIA IIRSA SUR) 


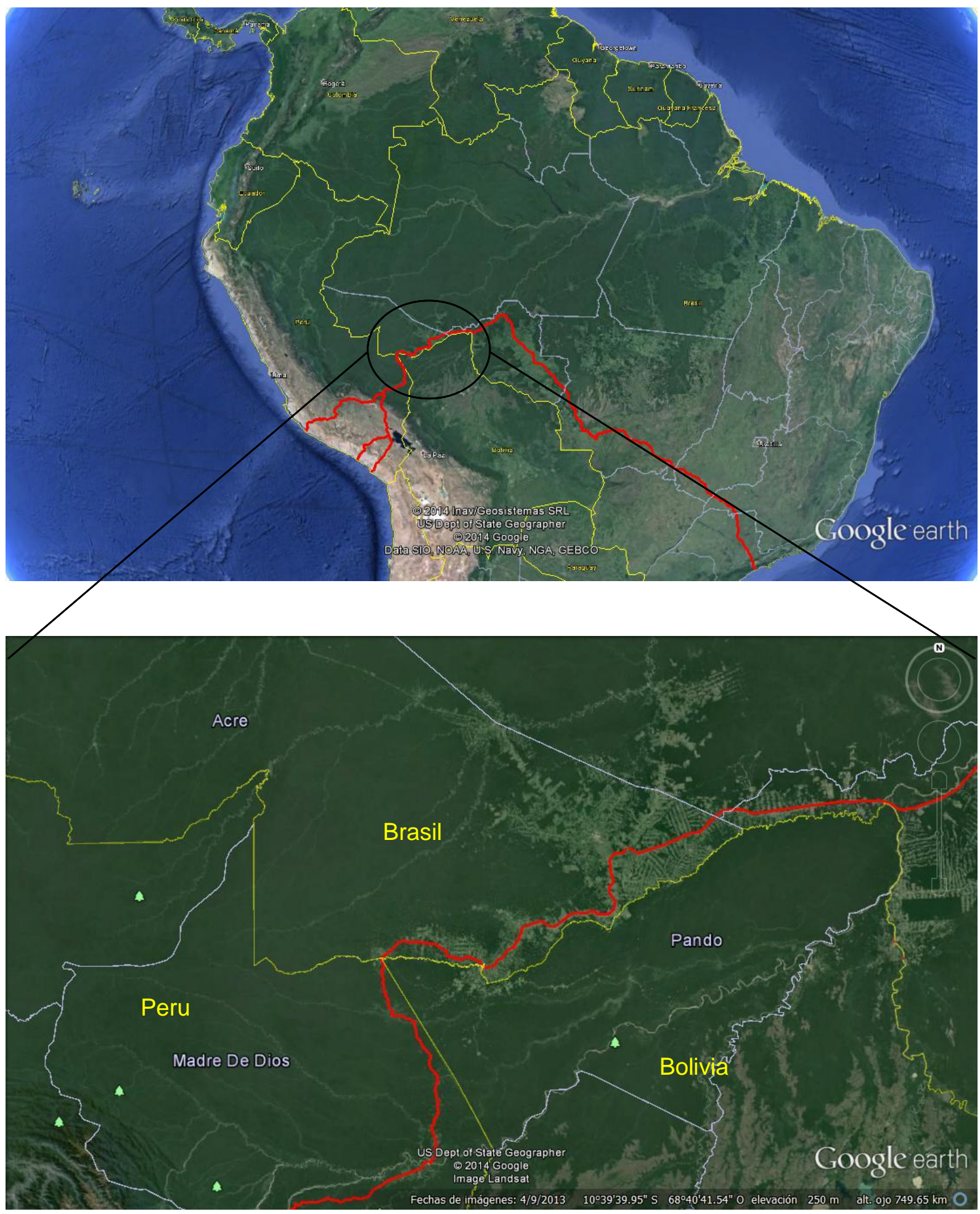

Figura 9 - Representação gráfica da Rodovia Interoceânica.

Fonte. Google Earth (2014)

Do lado peruano, o projeto consistiu na construção, reabilitação e melhoramento dos traçados que conformam a via que vai desde Iñapari em Madre de Dios, cruzando a macro região sul para chegar aos três portos marítimos do sul do Peru no oceano Pacífico (figura 10). No Brasil, consistiu na construção e melhoramento das 
rodovias BR 364, que foi pavimentada nos anos 80, e a rodovia BR 317. (BALVIN; PATRON, 2006)

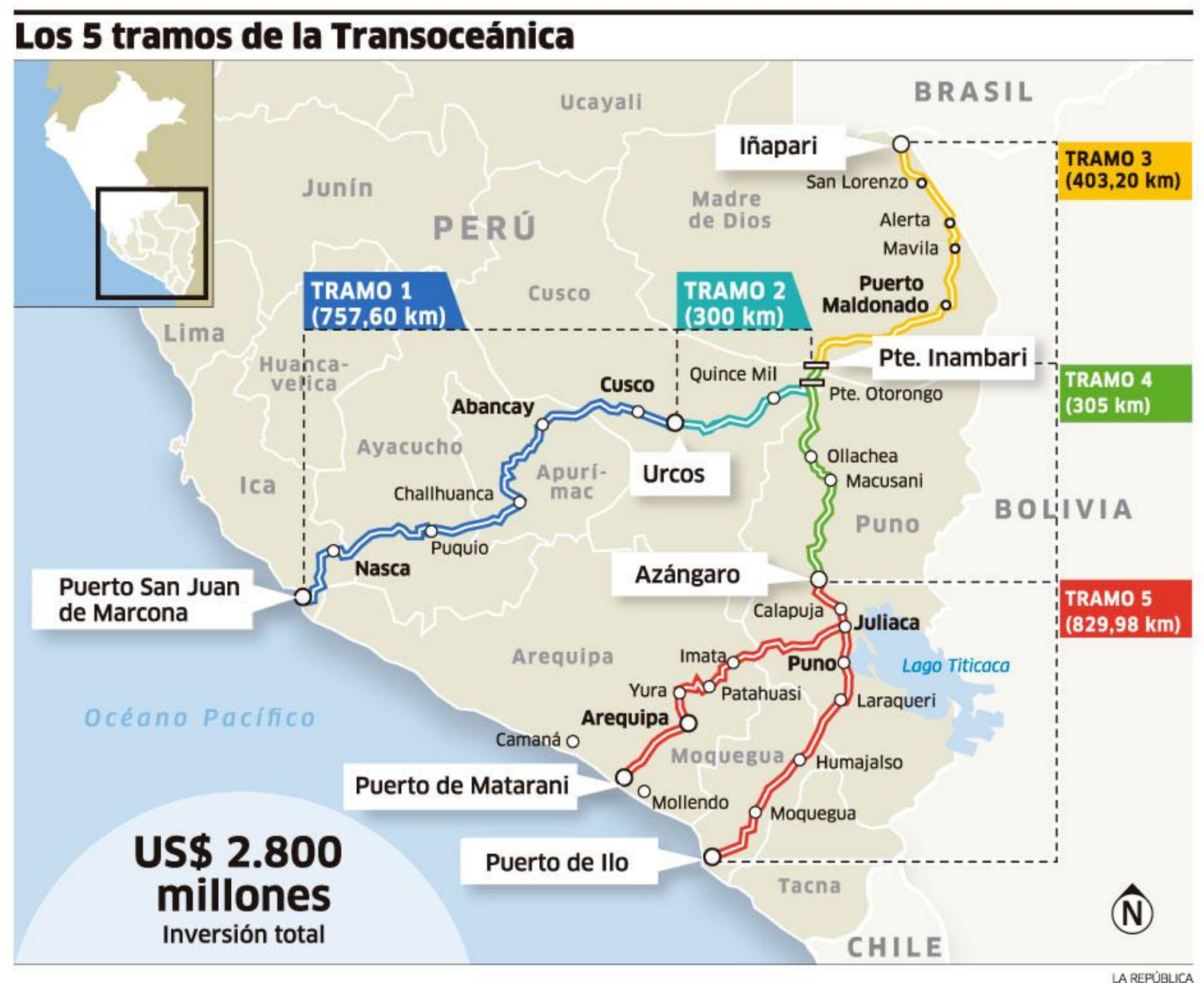

Figura 10 - Rodovia Interoceânica no Peru.

Fonte: GAMARRA (2013)

Esta rodovia faz parte da agenda política dos governos brasileiro e peruano desde 1981, quando foi assinado o primeiro acordo de interconexão rodoviária. E por mais de 30 anos vêm-se construindo caminhos transitáveis com o pretexto de criar saídas para a agricultura, mas que finalmente tem sido usadas para a extração ilegal de madeira e para a mineração, gerando um grande passivo ambiental na zona, que foi totalmente desconsiderado nos estudos de factibilidade para as atuais obras (BALVIN; PATRON, 2006; DOUROJEANNI, 2006).

Tal rodovia tem sido construída ao longo do tempo; no Brasil ela ficou pronta em 2002, no estado de Acre. Porém, no Peru só ficou pronta no ano 2010 e na Bolívia ainda falta pavimentar, mas o governo já anunciou sua pavimentação. Além de ser feita em espaços de tempo diferentes, também foi feita por etapas ou trechos dentro dos 
países, que é uma perigosa prática comumente usada para evadir as responsabilidades ambientais que surjam da somatória dos projetos. Isso acarretou na não realização de uma avaliação de impacto ambiental da totalidade da rodovia e, como consequência, não foram avaliados a totalidade dos impactos diretos e indiretos do projeto, nem os impactos cumulativos e sinérgicos ocasionados (DOUROJEANNI, 2006; HECK FRANCO, 2011; PERZ et al., 2013).

Inclusive dentro dos próprios países não foi avaliada a totalidade da rodovia. No caso peruano, foi aprovada sem que existisse um EIA completo de toda a rodovia e, em alguns trechos, os EIA foram aprovados depois de iniciada a execução do projeto, contrariando a normatividade vigente no Peru e o caráter preventivo do instrumento (BALVIN; PATRON, 2006; BRAVO ORELLANA, 2013; DOUROJEANNI, 2006; ECOLOGIA et al., 2008; HECK FRANCO, 2011; PAUTRAT et al., 2009; PERZ et al., 2010, 2013).

Segundo Dourojeanni (2006), as irregularidades com as quais foram aprovados e executados os EIA no Peru evidenciam a debilidade da legislação sobre o licenciamento ambiental. Em geral, mostra a baixa institucionalidade pública ambiental na decisão do setor que promove a obra avaliada. No capítulo ambiental do estudo de factibilidade e que foi usado para aprovar a execução inicial das obras, foi encontrado que estes não configuram uma EIA, pois trata-se de uma compilação de dados existentes, usualmente não atualizados, além de apresentar uma análise crítica fraca e se refere quase exclusivamente aos impactos diretos das obras. Além disso, não foram avaliados os impactos sobre a região fronteiriça da Bolívia, onde existem duas áreas protegidas, alegando que na legislação peruana os EIA do setor de transportes assume que só tem responsabilidade sobre os impactos nas imediações da obra e que é consequência direta da construção e do trânsito (DOUROJEANNI, 2006).

No lado peruano sua construção foi altamente questionada, tanto por suas características econômicas superdimensionadas e os vazios no processo de aprovação, quanto por representar um alto risco para o meio ambiente e as populações indígenas em isolamento voluntário que habitam a área, pois 3 (2,3 e 4) de seus 5 trechos atravessam 8 diferentes zonas biodiversas desde os Andes até a fronteira com Brasil e Bolívia, incluindo uma importante porção da a Amazônia melhor conservada de Madre de Dios, Cusco e Puno, com importante número de endemismos e espécies catalogadas como em via de extinção (BALVIN; PATRON, 2006; DOUROJEANNI, 2006; ECOLOGIA et al., 2008; PAUTRAT et al., 2009). 
Os impactos ambientais desta rodovia podem ser observados desde a década de 80, quando foi pavimentada a BR-364 que compõe a interoceânica em território brasileiro. Nesta época, provocou o que foi considerado um desastre ambiental e social no norte de Mato Grosso, Rondônia e Acre. O desastre medido em termos de desmatamento e invasão de terras indígenas foi de uma magnitude tão grande, que o BM e o BID criaram novos requisitos ambientais e sociais em suas operações para impedir de que fossem responsabilizados por novos desastres (DOUROJEANNI, 2006).

Os impactos ambientais frequentemente observados pela construção, mas especialmente pela pavimentação desta rodovia, são o incremento no desmatamento, invasão do território indígena, expansão da fronteira agrícola e atividades ilegais. São os impactos socioambientais diretos e indiretos os mais graves observados e que, por sua vez, geram maiores conflitos e impactos subsequentes, como a fragmentação de habitat e a consequente perda da biodiversidade, sendo uma grande ameaça para as comunidades indígenas que habitam a região (BALVIN; PATRON, 2006; DIJCK, 2013; DOUROJEANNI, 2006; GAMBOA; GUDYNAS, 2013; PAUTRAT et al., 2009; PERZ et al., 2013; RIBERA, 2011; REDWOOD, 2012)

Nos estudos realizados por PERZ e colaboradores (2013), sobre a relação entre a pavimentação das rodovias, o tempo de viagem e a alteração no uso do solo na região tri-fronteira do MAP na rodovia interoceânica, demonstrou-se que existe uma ligação muito importante entre estes fatores. Como consequência da pavimentação das rodovias de um país, a economia dos países vizinhos é afetada diretamente e aumenta-se a alteração do uso do solo. Nesta região em particular, os índices de desmatamento aumentaram, incrementando outros impactos relacionados, como a mineração, o desenvolvimento de atividades ilegais, a ampliação da fronteira agrícola, entre outros.

\subsection{Avaliação Ambiental e Social com foco estratégico da IIRSA. (Evaluación Ambiental y Social con enfoque estratégico - EASE)}

A avaliação ambiental e social com foco estratégico, EASE (sigla em espanhol), é uma metodologia desenvolvida pela Corporação Andina de Fomento (CAF), com o apoio do Banco Interamericano de Desenvolvimento (BID) (CAF, 2010, 2011). 
Foi concebida como um instrumento prático, para prover aos usuários da IIRSA uma conceituação e uma série de delineamentos práticos para a aplicação das avaliações ambientais e sociais, com foco estratégico nos diferentes grupos de projetos. É caracterizada por ser uma avaliação rápida e de baixo custo para a tomada de decisão. Baseada nos princípios da Avaliação Ambiental Estratégica,permite sua aplicação em diferentes níveis de análises, escalas, particularidades do território e do grupo e projetos (CAF, 2010, 2011; IIRSA, 2010b).

Propósitos:

$\checkmark$ Melhorar a compreensão dos territórios para potencializar seu desenvolvimento sustentável e otimizar os benefícios dos grupos de projetos;

$\checkmark$ Identificar cenários, tendências, aspectos críticos, implicações, riscos e oportunidades gerados nos territórios de influência dos grupos de projetos;

$\checkmark$ Planejar recomendações de formulação e implementação para os grupos de projetos;

$\checkmark$ Estabelecer estratégias, linhas de ação e inversões associadas, que gerem opções de desenvolvimento sustentável;

$\checkmark$ Facilitar um espaço para o diálogo construtivo entre os governos e os atores-chave da área de influência dos grupos de projetos (CAF, 2010).

Premissas:

$\checkmark$ A metodologia está fundamentada na necessidade de gerar resultados em curto prazo, oportunos e de alta qualidade técnica, para melhorar o processo de planificação e implementação da carteira de projetos da iniciativa IIRSA;

$\checkmark$ Sua aplicação requer a liderança de especialistas com grande experiência em áreas relacionadas com a avaliação ambiental e social.

$\checkmark$ Seu desenvolvimento está baseado em informação secundária e considera de alto valor as contribuições dos diferentes atores-chave em suas diversas fases;

$\checkmark$ Sua aplicação requer a participação e o compromisso pleno dos governos envolvidos, os quais se comprometem a designar uma 
contrapartida para integrar a equipe de trabalho (CAF, 2010; IIRSA, 2010b)

A metodologia é articulada de forma matricial sobre a base de um duplo jogo de insumos e atividades sequenciais que compreendem 5 componentes de 6 fases. Assim, os componentes correspondem a cada um dos elementos que devem ser utilizados na avaliação, e nas fases que são as etapas sucessivas, são desenvolvidas as atividades previstas (figura 11). Este processo está projetado para ser feito em um tempo limitado, podendo oscilar entre 4 e 5 meses, porém, segundo o apontado nas lições aprendidas em sua aplicação, pode ter uma duração maior de 7 a 10 meses dependendo do escopo e da complexidade da AAE ( DIJCK, 2013; IIRSA, 2010b). 


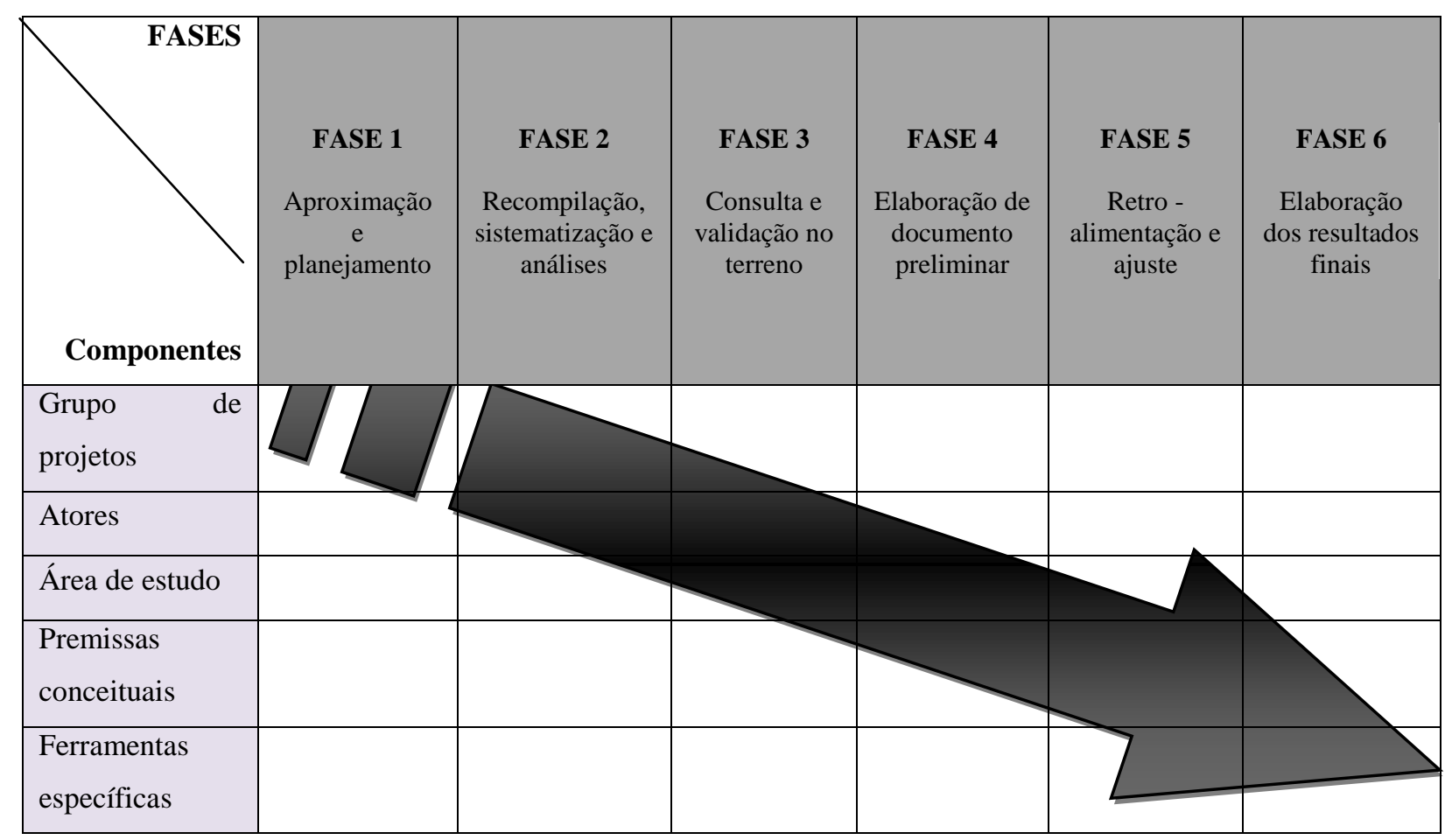

Figura 11 - Sínteses de Fases e componentes da EASE - IIRSA.

Fonte.IIRSA (2010b, tradução própria)

Como toda avaliação estratégica, um dos aspectos mais relevantes é a necessidade de atuar antecipadamente para prever as possíveis implicações derivadas do desenvolvimento de políticas, planos e programas, para orientar de maneira adequada a tomada de decisões encaminhadas à sustentabilidade. Para isso, atua na identificação precoce de fatores estratégicos que possam aumentar ou gerar riscos ou oportunidades de caráter ambiental e social nos territórios onde serão executadas as ações da IIRSA, como apresentado na figura 12 (CAF, 2010, 2011). 
Função estratégica do grupo de projetos

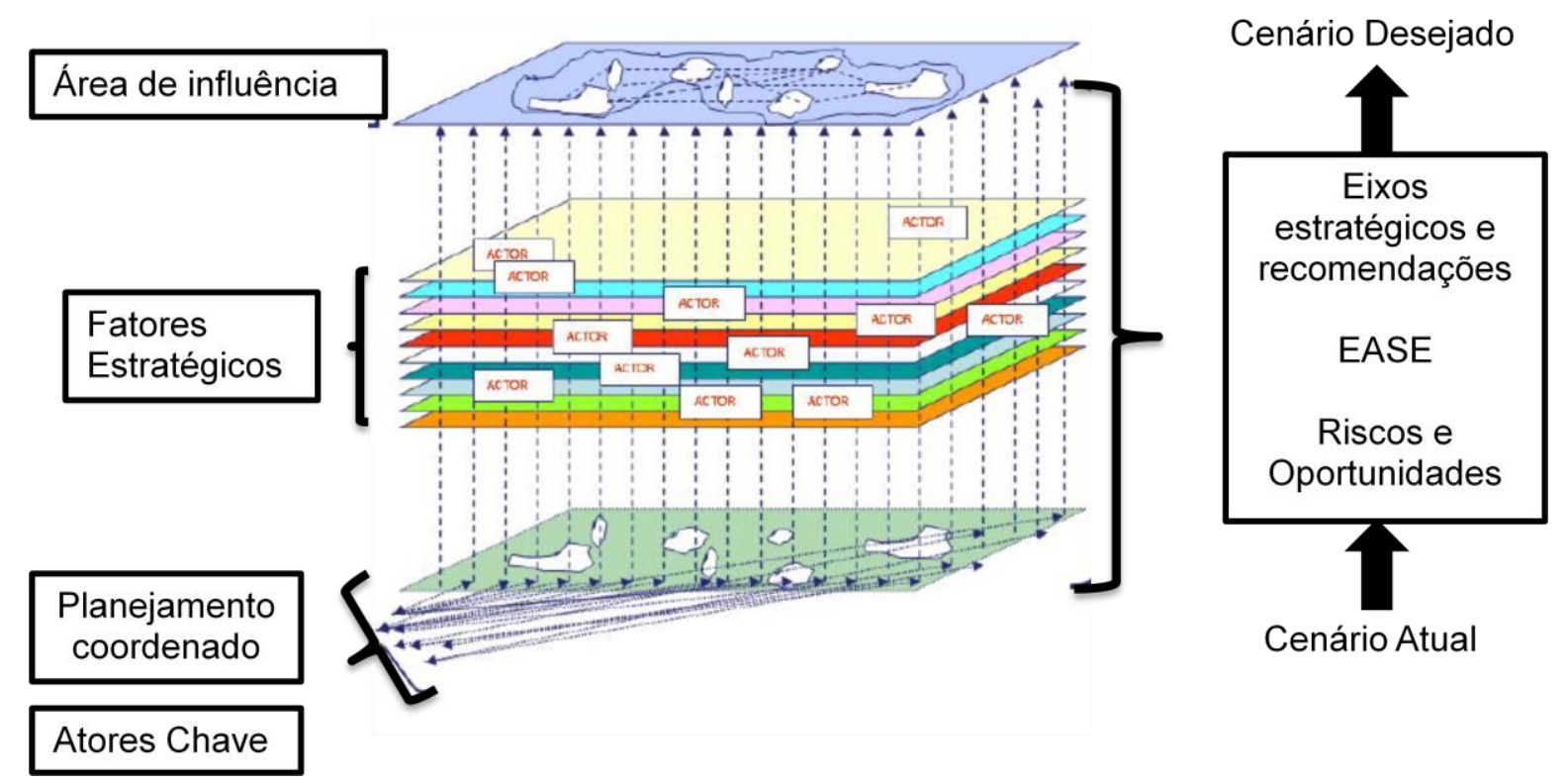

Figura 12 - Mapa conceitual da aplicação. Fonte.IIRSA, (2010b, tradução própria)

A complexidade da AAE, especialmente neste contexto de projetos binacionais e multinacionais, é derivada da dimensão política, institucional e social, onde é imperativa a coordenação e o acordo entre agentes que representam interesses diferentes. Por isso, é muito importante considerar sua adaptação ao contexto de aplicação, pois não é só um desafio técnico-metodológico, é principalmente um desafio político que influencia no processo de tomada de decisões estratégicas (IIRSA, 2010b).

A metodologia EASE está enquadrada num foco sistêmico, por isso permite a abordagem de problemas complexos, considera as dinâmicas do território, a organização institucional, a gestão de conflitos e toma decisões através de um conjunto de processos, procedimentos e instrumentos aplicáveis às diferentes instâncias de estudo e atuação (CAF, 2010).

Dentro dos principais produtos espera-se ter:

$\checkmark$ Uma informação consolidada do território e dos cenários de desenvolvimento;

$\checkmark$ A identificação de cenários, tendências, implicações, riscos, potencialidades e oportunidades oferecidas pelo território e pelo grupo de projetos, especialmente aqueles de tipo indireto, sinérgico e cumulativo;

$\checkmark$ Determinação e consulta dos atores-chave; 
Retroalimentação e validação de cenários e dos resultados definidos em termos de estratégia, linhas de ação prováveis e recomendações para reforçar a sustentabilidade do território associado ao grupo de projetos, que inclui uma estimativa de custos e dos requerimentos aproximados de inversão;

$\checkmark$ Recomendações de possíveis modificações de planificação, design e execução dos projetos;

$\checkmark$ Avaliação da capacidade institucional necessária para implementar os delineamentos da gestão ambiental e social, e as recomendações inerentes à aplicação da metodologia;

$\checkmark$ Identificação dos indicadores para prosseguimento da evolução e do comportamento das ações e dos territórios que serão interferidos para seu desenvolvimento (CAF, 2010).

Um ponto chave da metodologia é a identificação de cenários, e a partir deles serão dadas as recomendações necessárias para alcançar a meta de desenvolvimento sustentável. Essencialmente a metodologia trabalha com três cenários principais, evitável, tendencial e meta, como é esquematizado na figura 13 


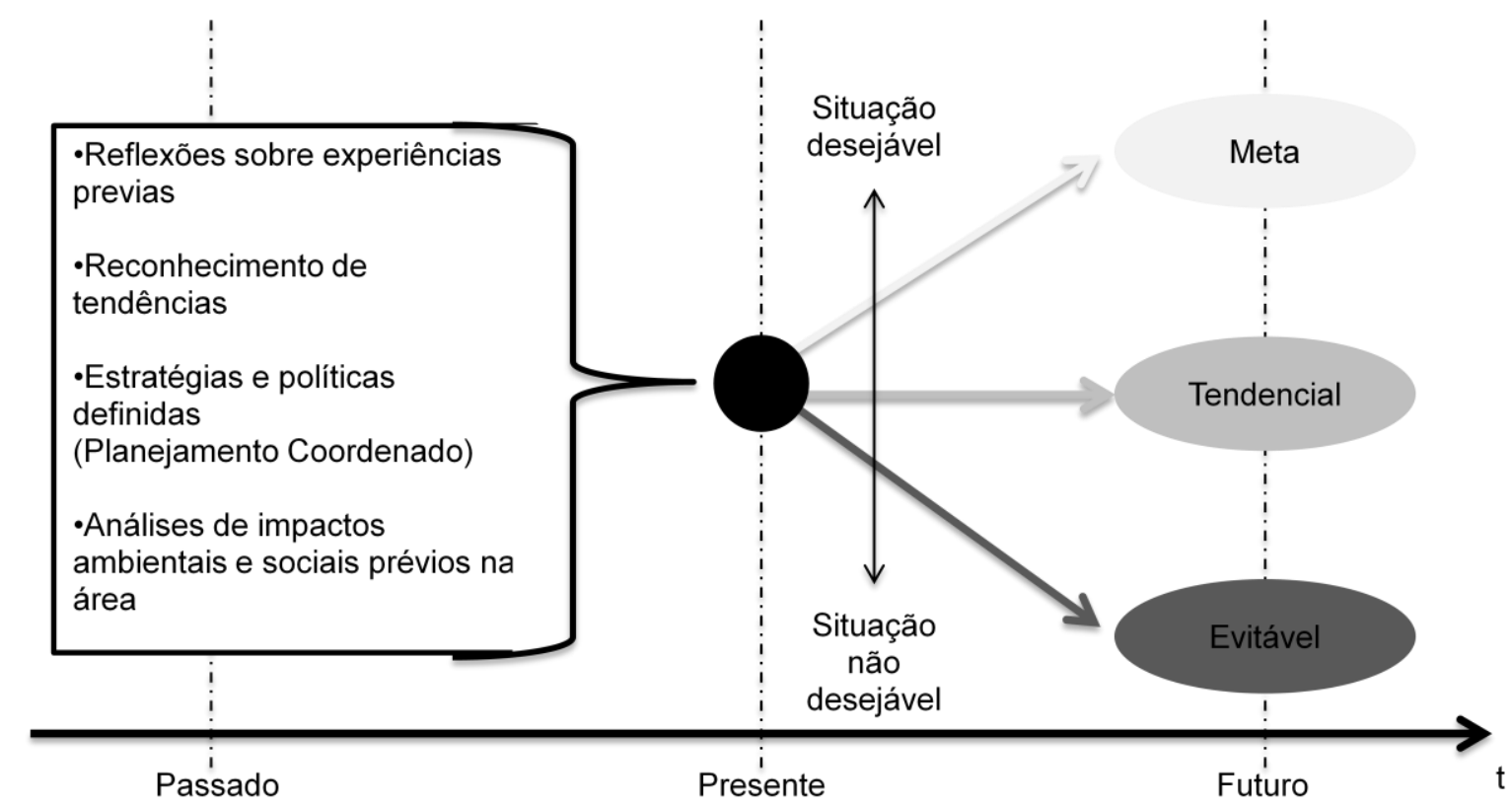

Figura 13 - Cenários considerados na aplicação da EASE.

Fonte. IIRSA (2010b, tradução própria)

Para testar, retroalimentar e fazer ajustes na metodologia, têm sido feitas até o momento 4 aplicações piloto, 3 em projetos binacionais e 1 em projeto nacional na Argentina. Pelo foco desta pesquisa, só vão ser levadas em conta as aplicações para o contexto binacional (CAF, 2011; IIRSA, 2010b, 2013; UNASUR et al., 2013). Assim, os 3 projetos de aplicação binacionais são:

\subsubsection{Grupo 6 do Eixo Andino - Conexão Colômbia - Equador II}

Está composto por 6 projetos que estão em diferentes graus de avanço (Figura 14). A função estratégica deste grupo é a de desenvolver um corredor que procure articular em esquemas de comércio internacional as zonas do centro e sul da Colômbia com as províncias amazônicas do norte e centro de Equador (Tena e Puyo), e as áreas no sul do Equador (Loja) (CAF, 2011). 


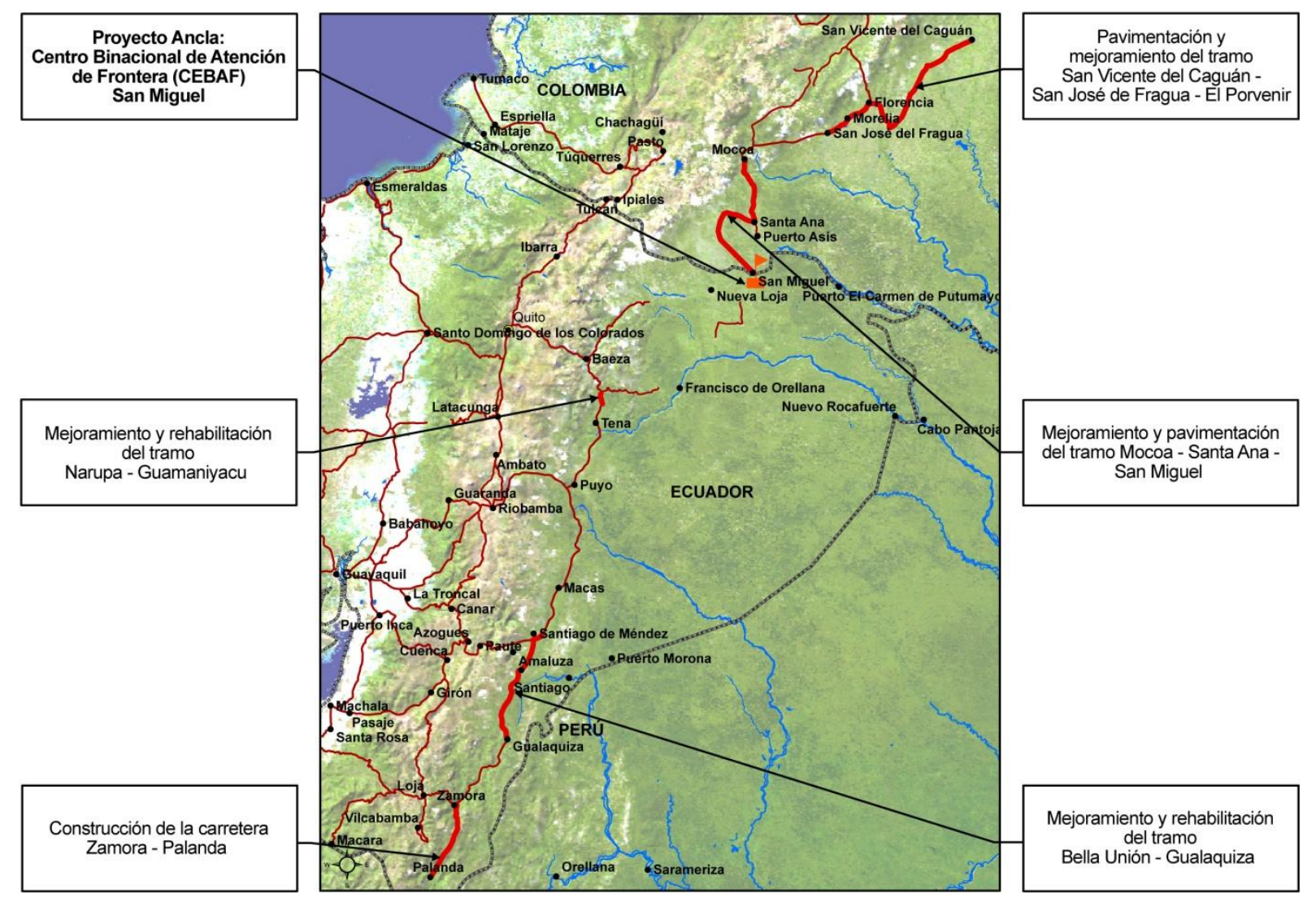

Figura 14 - Eixo Andino - Grupo 6 de projetos-Conexão Colômbia - Equador II. Fonte. GEOSUR (2014c)

\subsubsection{Grupo 2 do Eixo Sul - Circuito Turístico Binacional Zona dos Lagos (Argentina - Chile)}

O circuito turístico binacional, apesar de contar com um grande potencial de uso e crescimento, não tem sido desenvolvido como um produto integrado entre ambos países, através do estabelecimento de políticas, planos e programas destinados a potencializar a complementaridade entre os atrativos e capacidades de gestão existentes, tanto na Argentina quanto no Chile (ESPINOZA, 2013; IIRSA, 2010b).

Este grupo envolve 8 projetos vinculados ao transporte e à energia (Figura 15). Os "projetos âncora" que justificam um agrupamento em seu entorno, correspondem à adequação e manutenção das rotas Interlagos em ambos países. O objetivo principal deste grupo de projetos é o de consolidar um circuito turístico binacional nos territórios que são parte das províncias de Neuquén e Rio Negro, na Argentina, e nas regiões de Araucanía, Rios e Lagos no Chile, através do melhoramento da infraestrutura para ampliar a conectividade entre ambos países (IIRSA, 2010b).

As funções estratégicas do grupo de projetos são: fortalecimento do sistema turístico binacional na zona dos lagos, geração de oportunidades de desenvolvimento 
econômico e social com base neste recurso, conservação dos recursos ambientais e culturais (IIRSA, 2010b).

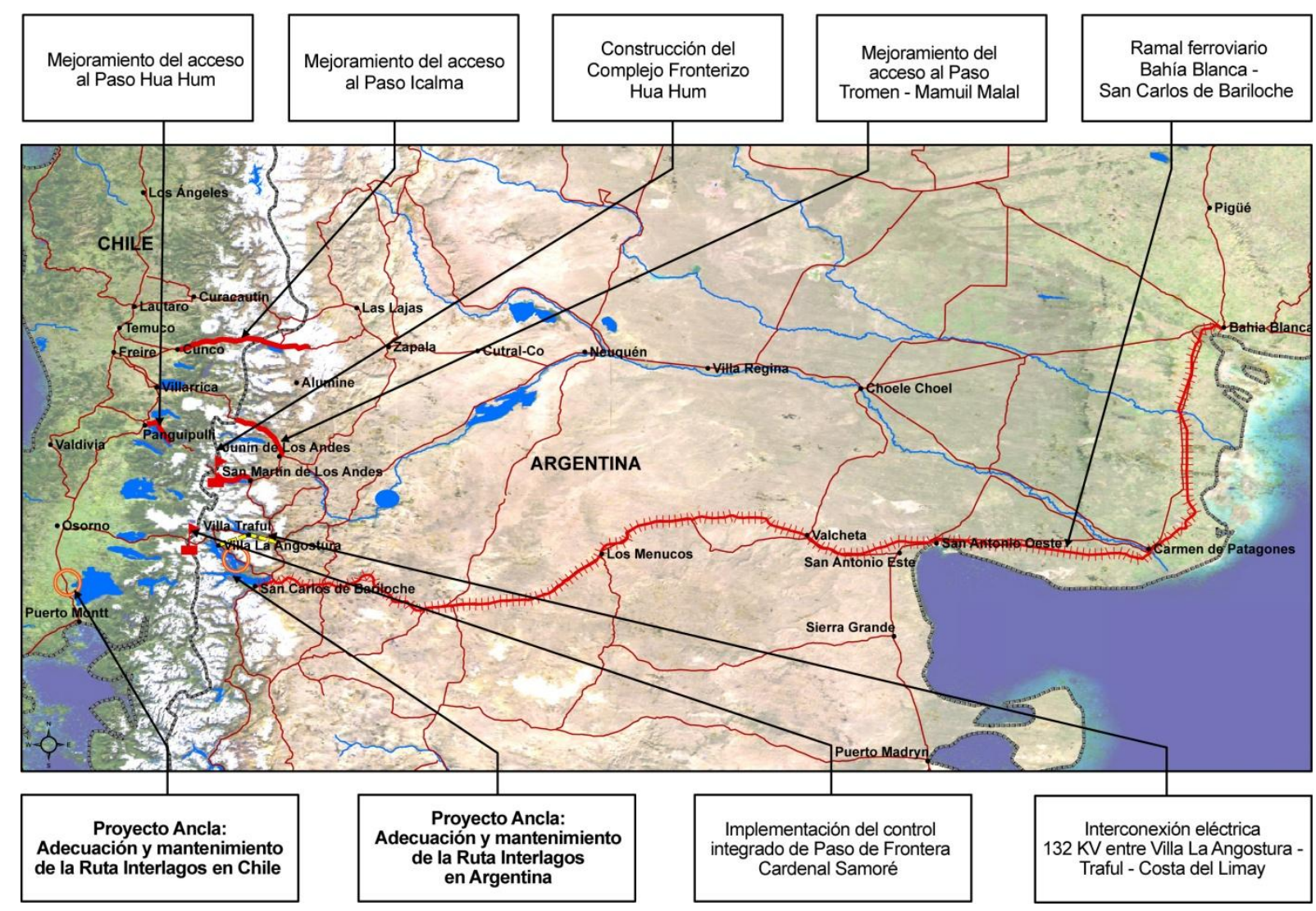

Figura 15 - Eixo Sul - Grupo 2 de projetos - Circuito Turístico binacional zona dos Lagos (Argentina - Chile)

Fonte. GEOSUR (2014d)

\subsubsection{Projeto de Transporte Multimodal no Sistema lagoa Mirim - Lagoa dos Patos (Brasil - Uruguai).}

Este projeto faz parte do eixo 7 - Mercosul - Chile e é fundamentado no acordo Brasil - Uruguai sobre o transporte fluvial e lacustre na hidrovia lagoa Mirim - Lagoa dos Patos (Figura 16), assinado em 30 de Julho de 2010. Seu objetivo estratégico é o de melhorar a conectividade entre a região leste do Uruguai e sul do Brasil, através da reativação do transporte fluvial e lacustre ( CAF, 2011; IIRSA, 2010b, 2013). 


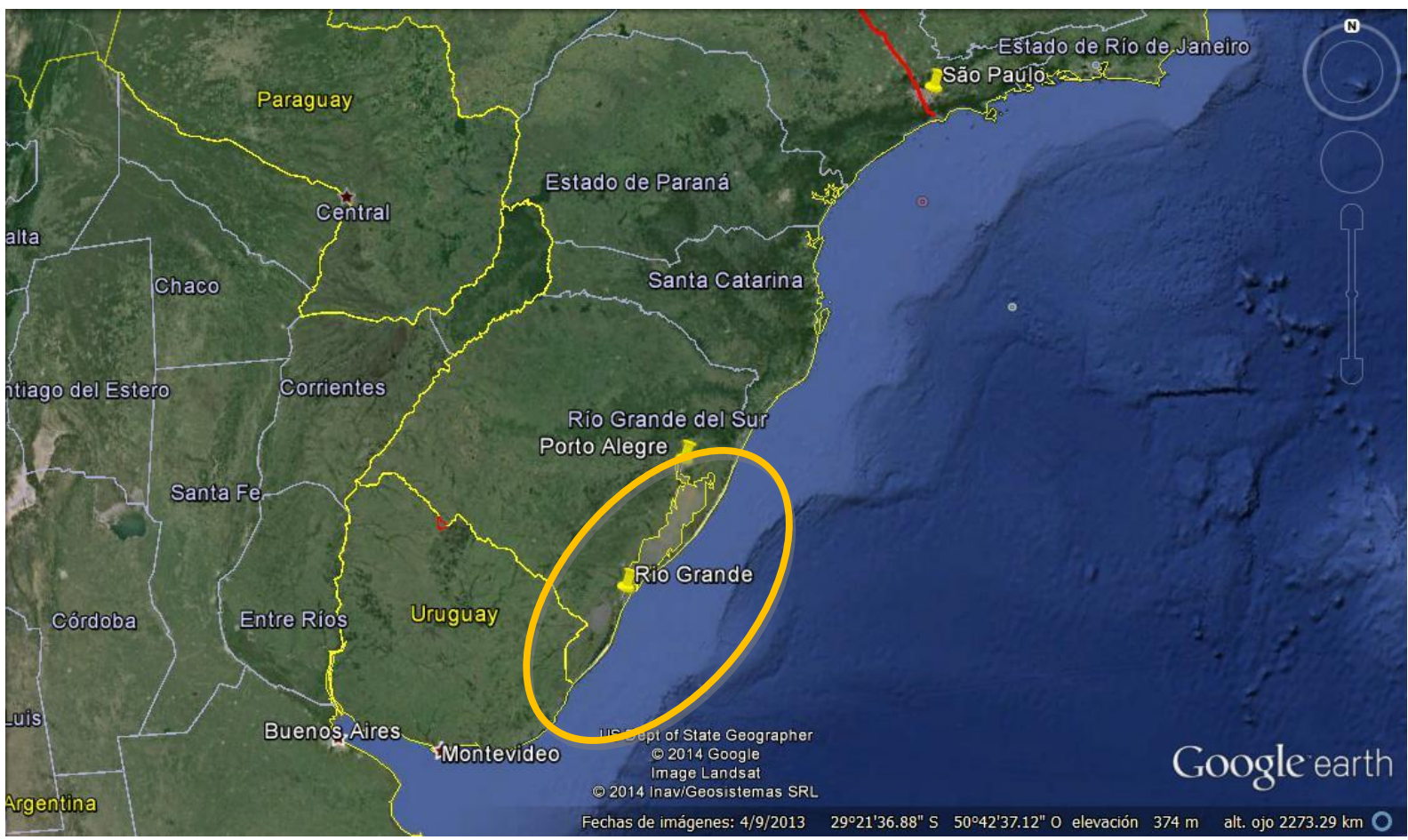

Figura 16 - Localização do projeto de transporte multimodal no sistema lagoa Mirim Lagoa dos Patos (Brasil - Uruguai)

Fonte:IIRSA (2014)

A ideia de desenvolver uma metodologia para atingir componentes socioambientais dos projetos da IIRSA surgiu em 2005 e depois de sete anos ainda encontra-se em aplicações piloto, como ilustrado a continuação.

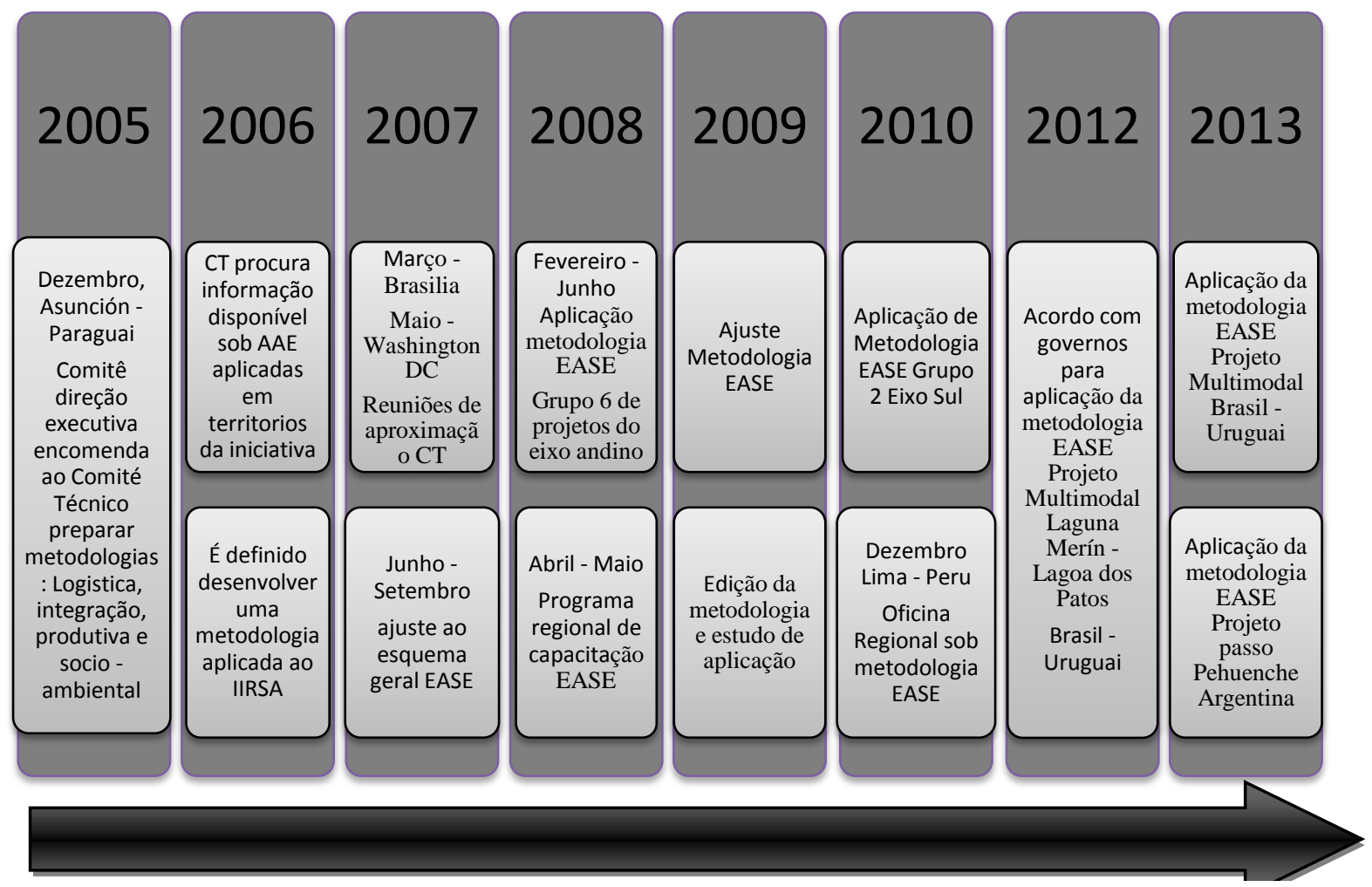

Figura 17 - Evolução da Metodologia EASE -IIRSA.

Fonte. IIRSA (2013, tradução própria) 
Segundo as lições aprendidas nas aplicações feitas, encontra-se que:

$\checkmark$ Existem limitações na quantidade e qualidade de informação estatística básica dos países, pois os sistemas e metodologia de captura, processamento, sistematização, análises e relatório, são diferentes em cada um deles. A falta de padronização restringe seu uso e análise, por isso é necessária sua homologação interna para tornar comparável a informação (CAF, 2010).

$\checkmark$ Existem restrições para o livre intercâmbio de dados e informações, uma vez que é importante desenvolver um protocolo para o intercâmbio de dados e informação entre países, além da elaboração de um set de dados geográficos básicos, que sirvam como ponto de partida para a elaboração de bases de dados, para as aplicações metodológicas e conteúdos mínimos para a provisão e uso de arquivos geográficos (IIRSA; EASE, 2010).

$\checkmark$ Há duplicação de esforços ao se recompilar informações secundárias, e, posteriormente, definir os indicadores(CAF, 2011).

$\checkmark$ Em alguns casos não existe infraestrutura, nem equipamento informático adequado para gerenciar os grandes volumes de dados necessários(CAF, 2011).

$\checkmark$ A aplicação da metodologia consegue colocar à disposição dos governos estratégias e linhas de ação em nível nacional e regional, associadas aos grupos de projetos sobre uma área de influência, que além de fortalecer a gestão ambiental dos projetos de cada grupo, em conjunto, pode ainda otimizar os cenários de sustentabilidade através da identificação de oportunidades que oferecem a harmonização e sinergia das atuações dos governos, setores produtivos e sociedade civil(CAF, 2011).

$\checkmark$ Os projetos de cada grupo apresentam diferentes níveis de desenvolvimento; alguns projetos só estão identificados, outros em fase de projeto , construção ou operação(CAF, 2011).

$\checkmark$ No caso da aplicação do grupo 6 de projetos (Colômbia - Equador), encontrou-se que as relações binacionais existentes na zona quando encerrou-se a aplicação da EASE - IIRSA, geraram sérias dificuldades para cumprir com a função estratégica e de conexão comercial entre o 
centro e sul da Colômbia, com as províncias amazônicas do norte e centro de Equador, o que é determinante na gestão diplomática de cada país e, em especial, para que a gestão binacional possa gerar o projeto âncora Centro Binacional de atenção na fronteira (CEBAF) (CAF, 2011).

$\checkmark$ A maior parte dos participantes nas fases de consulta, têm maior familiaridade com as metodologias de AIA, e pouca diferenciação e clarificação sobre os objetivos, alcances e resultados da metodologia EASE - IIRSA(CAF, 2011).

$\checkmark$ Existem limitações para a obtenção de uma informação temática confiável na escala de trabalho (1:500.000 a 1: 1.500.000), e a conformação de uma base de indicadores validados pelos organismos nacionais encarregados das estatísticas e dos censos, com a finalidade de construir indicadores que possam ser homologados e sistematizados para a análise de risco(CAF, 2011).

$\checkmark$ As atividades-chave para a efetiva aplicação da metodologia são: definição e contratação dos especialistas responsáveis pela execução do trabalho, a identificação e seleção dos fatores de análise e de definição, homogeneização e padronização de informação e indicadores sobre os fatores de análise. Isso para que cada país tenha seu próprio sistema e metodologia de captura, processamento e análise da informação(CAF, 2011).

$\checkmark$ Os atores-chave territoriais que participaram na aplicação da metodologia não revelaram ter interesse na integração regional, nem capacidade real de decisão sobre intervenções no território(CAF, 2011).

$\checkmark$ Foram encontrados vazios e deficiências de informação na área de influência dos grupos de projetos, sobre as ameaças naturais identificadas nos territórios, como: sismicidade, vulcanismo, enchentes e remoção em massa, vulnerabilidades físicas, econômicas e sociais das comunidades assentadas, e planos de gestão do risco local e regional a curto, médio e longo prazo(CAF, 2011).

$\checkmark$ A metodologia permite identificar oportunidades de intervenção no território, associadas aos grupos de projetos, independentemente do estado de avanço em que esteja a execução destes. As intervenções no 
território ou nas linhas de ação proposta estão orientadas a promover processos de desenvolvimento territorial com maior sustentabilidade(CAF, 2011).

$\checkmark$ Assim, existem consensos entre os diferentes atores que participaram do processo de aplicação sobre as linhas de ação propostas. Estes resultados não constituem acordos sociais, fundamentais para viabilizar a implementação das propostas, os quais deverão construir como passo seguinte a aplicação da metodologia EASE - IIRSA(CAF, 2011).

$\checkmark$ É importante fortalecer o papel dos coordenadores nacionais da IIRSA como vozeiros ao interior das entidades de cada país, para divulgar, promover a consulta e garantir a efetiva inclusão dos resultados da aplicação da metodologia EASE -IIRSA nos processos de formulação de políticas, planos e programas setoriais e territoriais(CAF, 2011).

$\checkmark$ Requer o design de um mecanismo expedito e oportuno para: dar a conhecer ao interior da institucionalidade de cada país a decisão de aplicar a metodologia EASE - IIRSA aos grupo de projetos selecionados; garantir desde o início o compromisso institucional de participação ativa no processo de aplicação e de aportar os insumos disponíveis para este efeito; realizar uma oportuna e efetiva comunicação para conseguir uma convocatória e participação exitosa dos atores e identificar consensos básicos para a formulação de linhas de ação em cumprimento dos objetivos e atividade previstas nas diferentes fases de sua aplicação(CAF, 2011).

$\checkmark$ Cada um dos projetos do grupo 6 estão em diferentes níveis de execução. Seu planejamento, execução e avaliação são feitos de maneira independente pelas instituições responsáveis por sua implementação em cada país. Cada projeto elabora uma análise de AIA e executa seu plano de gerenciamento socioambiental sem considerar os impactos indiretos, sinérgicos e cumulativos do grupo de projetos em seu conjunto, nem os impactos ou riscos derivados de outras intervenções setoriais em sua área de influência(CAF, 2011).

$\checkmark$ É necessário e determinante articular os estudos ambientais (AIA, PGA, gestão ou compra de terras e programas de realocação) dos projetos que se encontram em fase de projeto, através dos delineamentos estratégicos 
propostos como resultado da aplicação da metodologia EASE IIRSA(CAF, 2011).

$\checkmark$ É imperativo desenvolver e/ou ajustar o marco normativo dos países, para garantir que qualquer empreendimento de desenvolvimento esteja suportado em processos de informação precoce e em acordos derivados da participação, como princípio de atuação dos governos e um direito em sociedades democráticas(CAF, 2011).

$\checkmark$ É importante desenhar e implementar uma estratégia encaminhada à informar e promover de maneira permanente a participação de atores no processo de tomada de decisões sobre os projetos e obras a serem executadas, assim como em apresentar as possíveis implicações e as medidas de gerenciamentos previstas para evitar e reduzir os impactos, em especial sobre a população potencialmente afetada direta e indiretamente(CAF, 2011)

$\checkmark$ A metodologia tem alto potencial na geração de antecedentes para os processos de decisão e integração entre países, pois permite um melhor conhecimento da dinâmica dos territórios onde são inseridos os projetos e uma maior disponibilidade de informação relevante sobre cenários atuais e potenciais nas áreas de influência. Permite ainda a formulação de propostas para os processos de integração e sustentabilidade dos territórios, a instalação de diálogos entre os países, os quais ajudam a identificar as consequências e as formas de abordagens dos riscos e oportunidades ambientais e sociais a partir diversas visões e, por fim, a possibilidade de incutir discussões entre os países a respeito da sustentabilidade dos processos de integração(ESPINOZA, 2013).

$\checkmark$ Há a necessidade de manter uma continuidade no diálogo entre as equipes de trabalho, com o propósito de buscar um produto integrado, sobre a tendência de considerar visões unilaterais desde cada país ou setor envolvido (ESPINOZA, 2013).

$\checkmark$ A EASE proporciona uma visão global, multissetorial, ordenada e com propostas para discutir as políticas concretas sem perder de vista o panorama total. (IIRSA, 2013)

$\checkmark$ A integração regional requer, além do relacionamento diplomático entre países, um apoio comprometido da integração real no território, para 
potencializar as fortalezas e convertê-las em benefícios concretos(ESPINOZA et al., 2010).

$\checkmark$ Um desafio importante é o de vencer a burocracia atual que impede ou dificulta a integração das dinâmicas cotidianas fronteiriças dos países(ESPINOZA et al., 2010).

$\checkmark$ É importante a definição das áreas de influência direta e indireta, onde a direta é a que apresenta riscos e oportunidades ambientais e sociais, e a indireta é aquela produzida por sinergias e interações com outras iniciativas estratégicas que influenciam sobre a área direta(ESPINOZA et al., 2010).

$\checkmark$ A definição destas áreas está condicionada à disponibilidade de informação, tanto em sua relação com os temas-chave, como com os tempos e formatos compatíveis com o prazo de aplicação. Um ponto crítico a esse respeito segue da necessidade de fazer coincidir na medida do possível os limites das áreas de influência com os das jurisdições administrativas, onde são geradas informações estatísticas por parte da maioria dos países que conformam a IIRSA(ESPINOZA et al., 2010).

$\checkmark$ Um dos fundamentos da EASE é o uso de informação secundária relevante aos propósitos da aplicação. Por isso, é importante desde o início, focar no trabalho da obtenção de antecedentes validados pelas equipes, consolidando um conjunto de critérios que permitam superar tanto as assimetrias de informação entre os países, quanto o problema de sua disponibilidade efetiva nos tempos reais da aplicação(ESPINOZA et al., 2010).

Segundo a reunião do grupo técnico executivo da EASE, realizada em 24 de setembro de 2013, em Santiago do Chile, não há um conhecimento homogêneo sobre o uso da ferramenta, nem todos os países da IIRSA tem participado na aplicação. A aplicação da metodologia requer o compromisso e envolvimento das equipes políticas e técnicos nacionais, uma vez que isso possibilita o fortalecimento institucional das áreas de planificação, tanto em nível central, quanto local, e a apropriação dos resultados alcançados, bem como a difusão interna dos resultados e a contribuição na tomada de decisões. É importante realizar uma avaliação para aperfeiçoar a metodologia depois de 
contar com uma massa crítica de aplicações que inclua a maioria dos países (UNASUR et al., 2013).

Segundo Dijck, 2013, o intervalo de tempo para fazer uma AAE é muito limitado e ele questiona igualmente o uso de uma base única de evidências disponível. Também discute que não é clara em qual medida um foco participativo pode ser realizado dependendo só dos atores-chave. Segundo ele, há muitos desafios no desenvolvimento de uma metodologia com estas características estratégicas; existem muitas variáveis exógenas que vão desde a biofísica até aos fatores socioeconômicos que interagem com as decisões sobre o uso do solo em curto e longo prazo, o que mostra que a modelação dos processos de interação não é uma opção realista no contexto da AAE.

Por fim, conclui que apesar da AAE ser uma ferramenta poderosa, a falta de uma metodologia geralmente acertada, e as limitações como a exatidão da avaliação dos impactos socioeconômicos e biofísicos, seguem afetando as contribuições da AAE na sustentabilidade. Além disso, a tendência dos governos e das instituições financeiras para dar prioridade à inversão em infraestrutura por razões econômicas, e de limitar a distribuição de tempo e orçamento para avaliações completas de impacto, é traduzido num subuso das possibilidades do instrumento. Igualmente, a extemporaneidade é a inadequada integração dos resultados, a tomada de decisões limita o uso efetivo da AAE e esta termina sendo só um exercício a mais (DIJCK, 2013). 


\section{ANÁLISE DA CONFORMIDADE COM OS PRINCÍPIOS DE AIA - T EM NÍVEL MUNDIAL.}

Como já foi descrito, os princípios para a AIA - T foram estabelecidos nas Conferências das Nações Unidas sobre Ambiente Humano (Estocolmo 1972) e sobre Meio Ambiente e Desenvolvimento (Rio - 92). Em nível mundial, a referência pelo estabelecimento de pautas claras para o desenvolvimento desta ferramenta é a convenção de Espoo e, dentre os países signatários, a União Europeia sobressai por ter assimilado a convenção de maneira vinculante entre seus países através das diretivas europeias e por sua aplicação recorrente com casos de sucesso, pelo que foram tomadas tais bases para responder a objetivo especifico 3: avaliar a conformidade do quadro institucional e metodológico dos casos selecionados com os princípios e as melhores práticas da AIA - T em nível mundial.

No capítulo 5, fica evidente que o quadro institucional da AIA - T nos países amazônicos é muito fraco e quase inexistente. A maioria destes países têm políticas onde se reflete um forte compromisso no cumprimento dos acordos bilaterais e multilaterais assinados, assim como a promoção da cooperação internacional e de normativas bem definidas para a realização da AIA. Porém, só a Bolívia, o Brasil e a Colômbia apresentam alguns pontos gerais em suas normativas no caso de existir impactos ambientais transfronteiriços, mas não o suficientemente claros e completos como para orientar um processos de AIA-T.

Nos órgãos sub-regionais, apesar de se ter avanços no trabalho conjunto, que poderia subsidiar uma adequada AIA - T, todavia não se tem caminhado nessa direção, ainda falta um maior compromisso e vontade política por parte dos Estados, além da necessidade de melhora dos sistemas nacionais de AIA.

$\mathrm{Na}$ prática, segundo o evidenciado nos casos analisados neste capitulo, o quadro institucional de base, que politicamente está medianamente bem estabelecido para a realização de AIA para projetos, ainda tem fortes fraquezas; dentre essas, as mais importantes são a realização de processos de AIA com forte influência política e visando só o para o licenciamento, como um ato protocolar e burocrático, excluindo as potencialidades reais da ferramenta.

Na tabela 6, é apresentado como os casos analisados aplicaram ou não as etapas que, segundo a convenção de Espoo, deveriam ser seguidas quando houvesse 
possíveis impactos transfronteiriços, que foram descritos no item 4.4, os quais por sua vez se correspondem com os princípios estabelecidos nas convenções de Estocolmo, 72 e Rio, 92.

Tabela 5 - Análise dos estudos de caso em termos de conformidade com os princípios e melhores práticas de AIA - T

\begin{tabular}{|c|c|c|c|c|c|c|c|}
\hline \multirow{2}{*}{$\begin{array}{c}\text { Princípios } \\
\text { AIA - T, } \\
\text { Estocolmo } \\
72 \text { e } \\
\text { Rio - } 92\end{array}$} & \multirow{2}{*}{$\begin{array}{c}\text { Passos } \\
\text { AIA - T e } \\
\text { AAE - T } \\
\text { Espoo } \\
1991 \text { e } \\
\text { protocolo } \\
\text { de Kiev } \\
2003 \text {. }\end{array}$} & \multicolumn{2}{|c|}{$\begin{array}{c}\text { Caso Complexo } \\
\text { Hidrelétrico Rio } \\
\text { Madeira. } \\
\text { Brasil - Bolívia }\end{array}$} & \multicolumn{2}{|c|}{$\begin{array}{c}\text { Caso Rodovia } \\
\text { Interoceânica. } \\
\text { Brasil - Peru }\end{array}$} & \multicolumn{2}{|c|}{$\begin{array}{c}\text { Aplicação da } \\
\text { metodologia EASE. }\end{array}$} \\
\hline & & Cumpre & Obs. & Cumpre & Obs. & Cumpre & Obs. \\
\hline \multirow[t]{2}{*}{$\begin{array}{c}\text { Boa } \\
\text { vizinhança }\end{array}$} & $\begin{array}{l}\text { Verificação } \\
\text { Preliminar } \\
\text { da } \\
\text { existência } \\
\text { de possíveis } \\
\text { impactos } \\
\text { ambientais } \\
\text { trans - } \\
\text { Fronteiriços. }\end{array}$ & Não & $\begin{array}{l}\text { Inicialmente } \\
\text { não. } \\
\text { Foram } \\
\text { percebidos em } \\
\text { estados } \\
\text { avançados do } \\
\text { processo de } \\
\text { licenciamento e } \\
\text { pela parte } \\
\text { afetada. foram } \\
\text { Não } \\
\text { identificados } \\
\text { nos EIA. }\end{array}$ & Não & $\begin{array}{l}\text { A forma como } \\
\text { foi licenciada } \\
\text { não permite sua } \\
\text { percepção. }\end{array}$ & Sim & $\begin{array}{l}\text { Faz parte da } \\
\text { finalidade. }\end{array}$ \\
\hline & $\begin{array}{l}\text { Delimitação } \\
\text { do escopo. }\end{array}$ & Sim & \begin{tabular}{lr}
\multicolumn{2}{l}{ Estreito só para } \\
a bacia do rio \\
Madeira & no \\
Brasil. & \\
\end{tabular} & Sim & $\begin{array}{l}\text { Só por trechos, } \\
\text { segundo } \quad \mathrm{o} \\
\text { esquema de } \\
\text { licenciamento. }\end{array}$ & Sim & $\begin{array}{l}\text { Para os grupos } \\
\text { de projetos de } \\
\text { cada eixo. }\end{array}$ \\
\hline \multirow[t]{2}{*}{ Notificação } & $\begin{array}{l}\text { Notificação } \\
\text { e determina } \\
\text { - ção do } \\
\text { prazo de } \\
\text { resposta. }\end{array}$ & Não & $\begin{array}{lr}\text { Quem tomou } & \text { a } \\
\text { iniciativa foi } & \text { a } \\
\text { Bolívia, } & \text { o } \\
\text { governo } & \\
\text { brasileiro } & \text { só } \\
\text { aceitou } & \text { os } \\
\text { possíveis } & \\
\text { impactos } & \text { na } \\
\text { Bolívia } & \text { em } \\
\text { 2009, } & \text { na } \\
\text { comissão } & \\
\text { conjunta } & \text { de } \\
\text { análise. } & \\
\end{array}$ & Não & $\begin{array}{l}\text { Não foram } \\
\text { identificados } \\
\text { nem tratados os } \\
\text { impactos } \\
\text { transfronteiriços }\end{array}$ & Não & $\begin{array}{l}\text { Não nos termos } \\
\text { de Espoo, esta } \\
\text { avaliação é } \\
\text { iniciativa de um } \\
\text { órgão de } \\
\text { financiamento } \\
\text { que incentiva } \\
\text { uma conversa } \\
\text { entre os países. }\end{array}$ \\
\hline & $\begin{array}{l}\text { Resposta da } \\
\text { parte } \\
\text { afetada } \\
\text { decidindo } \\
\text { sua } \\
\text { participação } \\
\text { no processo } \\
\text { de AIA. }\end{array}$ & Não & $\begin{array}{l}\text { Não houve } \\
\text { notificação, } \\
\text { portanto não } \\
\text { houve resposta. } \\
\text { Bolívia solicitou } \\
\text { participação, } \\
\text { fizeram-se } \\
\text { reuniões } \\
\text { conjuntas, } \\
\text { porém não } \\
\text { afetou }\end{array}$ & Não & $\begin{array}{l}\text { Não houve } \\
\text { notificação, } \\
\text { portanto não } \\
\text { houve resposta. }\end{array}$ & Não & $\begin{array}{l}\text { Não houve } \\
\text { notificação, } \\
\text { portanto não } \\
\text { houve resposta. } \\
\text { É uma trabalho } \\
\text { conjunto } \\
\text { liderado pela } \\
\text { CAF - IIRSA, } \\
\text { por isso os } \\
\text { países estão na }\end{array}$ \\
\hline
\end{tabular}




\begin{tabular}{|c|c|c|c|c|c|c|c|}
\hline \multirow[t]{2}{*}{$\begin{array}{c}\text { Princípios } \\
\text { AIA - T, } \\
\text { Estocolmo } \\
72 \text { e } \\
\text { Rio - } 92\end{array}$} & $\begin{array}{c}\text { Passos } \\
\text { AIA - T e } \\
\text { AAE - T } \\
\text { Espoo } \\
1991 \text { e } \\
\text { protocolo } \\
\text { de Kiev } \\
2003 \text {. }\end{array}$ & \multicolumn{2}{|c|}{$\begin{array}{c}\text { Caso Complexo } \\
\text { Hidrelétrico Rio } \\
\text { Madeira. } \\
\text { Brasil - Bolívia }\end{array}$} & \multicolumn{2}{|c|}{$\begin{array}{c}\text { Caso Rodovia } \\
\text { Interoceânica. } \\
\text { Brasil - Peru }\end{array}$} & \multicolumn{2}{|c|}{$\begin{array}{c}\text { Aplicação da } \\
\text { metodologia EASE. }\end{array}$} \\
\hline & & & $\begin{array}{l}\text { processo de } \\
\text { construção das } \\
\text { hidrelétricas. }\end{array}$ & & & & $\begin{array}{l}\text { mesma mesa } \\
\text { desde o inicio. }\end{array}$ \\
\hline \multirow{3}{*}{$\begin{array}{l}\text { Coopera- } \\
\text { ção } \\
\text { internacio- } \\
\text { nal }\end{array}$} & $\begin{array}{l}\text { Envio por } \\
\text { parte do } \\
\text { país de } \\
\text { origem da } \\
\text { informação } \\
\text { sobre o } \\
\text { processo de } \\
\text { AIA à parte } \\
\text { afetada. } \\
\end{array}$ & Sim & $\begin{array}{l}\text { Solicitação da } \\
\text { Bolívia, porém } \\
\text { não houve } \\
\text { aprofundamento } \\
\text { no assunto. }\end{array}$ & Não & $\begin{array}{l}\text { Não foram } \\
\text { identificados os } \\
\text { impactos } \\
\text { transfronteiriços } \\
\text { por nenhuma } \\
\text { das partes. }\end{array}$ & Não & $\begin{array}{lr}\text { É um processo } \\
\text { com fom } \\
\text { estratégico } \\
\text { existe } \\
\text { intercâmbio } \\
\text { mútuo } \\
\text { informação. }\end{array}$ \\
\hline & $\begin{array}{l}\text { Preparação } \\
\text { da } \\
\text { documenta - } \\
\text { ção básica } \\
\text { para a AIA } \\
\text { e } \\
\text { compartilha } \\
\text { - mento de } \\
\text { informação } \\
\text { entre países. }\end{array}$ & $\mathrm{Sim}$ & $\begin{array}{l}\text { A solicitude da } \\
\text { Bolívia, porem } \\
\text { não houve } \\
\text { aprofundamento } \\
\text { no assunto. }\end{array}$ & Não & $\begin{array}{l}\text { Não foram } \\
\text { identificados os } \\
\text { impactos } \\
\text { transfronteiriços } \\
\text { por nenhuma } \\
\text { das partes. }\end{array}$ & Sim & $\begin{array}{l}\text { Compartilha } \\
\text { mento mútuo de } \\
\text { informação } \\
\text { preparação da } \\
\text { documentação } \\
\text { com um foco } \\
\text { estratégico. }\end{array}$ \\
\hline & $\begin{array}{l}\text { Consultas } \\
\text { entre as } \\
\text { partes } \\
\text { interessadas } \\
\text { (participaçã } \\
\text { o pública). }\end{array}$ & Não & $\begin{array}{l}\text { Não com a } \\
\text { população ao } \\
\text { nível } \\
\text { transfronteiriço. } \\
\begin{array}{l}\text { Só entre os altos } \\
\text { mandos do } \\
\text { governo. }\end{array} \\
\end{array}$ & Não & $\begin{array}{l}\text { Não foram } \\
\text { identificados os } \\
\text { impactos } \\
\text { transfronteiriços } \\
\text { por nenhuma } \\
\text { das partes. }\end{array}$ & Não & $\begin{array}{l}\text { Só são } \\
\text { consultados os } \\
\text { atores chave que } \\
\text { não representa a } \\
\text { maioria da } \\
\text { população. }\end{array}$ \\
\hline \multirow{3}{*}{$\begin{array}{l}\text { Soberania } \\
\text { estatal } \\
\text { sobre os } \\
\text { recursos } \\
\text { naturais }\end{array}$} & $\begin{array}{l}\text { Comunica - } \\
\text { ção da } \\
\text { decisão } \\
\text { definitiva à } \\
\text { parte } \\
\text { afetada. }\end{array}$ & Não & $\begin{array}{l}\text { Não } \\
\text { Formalmente, } \\
\text { existiram } \\
\text { interesses } \\
\text { econômicos } \\
\text { políticos que } \\
\text { frearam o } \\
\text { processo de } \\
\text { análise conjunta } \\
\text { dos impactos. } \\
\end{array}$ & Não & $\begin{array}{l}\text { Não foram } \\
\text { identificados os } \\
\text { impactos } \\
\text { transfronteiriços } \\
\text { por nenhuma } \\
\text { das partes. }\end{array}$ & Não & $\begin{array}{l}\text { A ferramenta da } \\
\text { sustento } \\
\text { tomada } \\
\text { decisão, está em } \\
\text { aplicação piloto, } \\
\text { não tem muita } \\
\text { influência nas } \\
\text { decisões. }\end{array}$ \\
\hline & $\begin{array}{l}\text { Definição } \\
\text { dos termos } \\
\text { para a } \\
\text { análise } \\
\text { posterior do } \\
\text { projeto. }\end{array}$ & Não & $\begin{array}{l}\text { Estão definindo } \\
\text { medidas para a } \\
\text { solução das } \\
\text { problemáticas já } \\
\text { causadas pela } \\
\text { construção das } \\
\text { UHE. }\end{array}$ & Não & $\begin{array}{l}\text { Não foram } \\
\text { identificados os } \\
\text { impactos } \\
\text { transfronteiriços } \\
\text { por nenhuma } \\
\text { das partes. }\end{array}$ & Não & $\begin{array}{l}\text { Estão em } \\
\text { aplicação piloto. }\end{array}$ \\
\hline & $\begin{array}{l}\text { Solução de } \\
\text { controvérsia } \\
\text { s. }\end{array}$ & Não & $\begin{array}{l}\text { Não nos termos } \\
\text { de Espoo, pois } \\
\text { não foi feita } \\
\text { uma AIA - T. } \\
\text { Porém, o } \\
\text { processo todo é } \\
\text { uma }\end{array}$ & Não & $\begin{array}{l}\text { Não foram } \\
\text { identificados os } \\
\text { impactos } \\
\text { transfronteiriços } \\
\text { por nenhuma } \\
\text { das partes. }\end{array}$ & Não. & $\begin{array}{l}\text { Estão } \quad \text { em } \\
\text { aplicação piloto. }\end{array}$ \\
\hline
\end{tabular}




\begin{tabular}{|c|c|c|c|c|}
\hline \multirow[t]{2}{*}{$\begin{array}{c}\text { Princípios } \\
\text { AIA - T, } \\
\text { Estocolmo } \\
72 \text { e } \\
\text { Rio - } 92\end{array}$} & $\begin{array}{c}\text { Passos } \\
\text { AIA - T e } \\
\text { AAE - T } \\
\text { Espoo } \\
1991 \text { e } \\
\text { protocolo } \\
\text { de Kiev } \\
2003 \text {. }\end{array}$ & $\begin{array}{c}\text { Caso Complexo } \\
\text { Hidrelétrico Rio } \\
\text { Madeira. } \\
\text { Brasil - Bolívia }\end{array}$ & $\begin{array}{c}\text { Caso Rodovia } \\
\text { Interoceânica. } \\
\text { Brasil - Peru }\end{array}$ & $\begin{array}{c}\text { Aplicação da } \\
\text { metodologia EASE. }\end{array}$ \\
\hline & & $\begin{array}{l}\text { controvérsia; até } \\
\text { hoje continua a } \\
\text { tentativa de se } \\
\text { encontrar uma } \\
\text { solução. }\end{array}$ & & \\
\hline
\end{tabular}

Fonte: Elaboração própria.

Os interesses envolvidos nas megaobras que estão sendo desenvolvidas na América do Sul e a pressa pela aprovação dos projetos, faz com que os governos façam o possível para "evitar" ou melhor, ignorar os impactos transfronteiriços, exercendo pressão nos órgãos licenciadores para sua aprovação, que muitas vezes ocorre num marco de irregularidades, como visto nos casos do rio Madeira e da Rodovia Interoceânica.

No caso do rio Madeira, foram percebidos os discursos contraditórios do governo brasileiro: por um lado assina acordos internacionais para proteger o ambiente, faz o Plano Amazônia Sustentável, porém depois exerce pressão nos órgãos ambientais para licenciar projetos com potencialidade de causar grandes impactos ambientais tanto nacionais quanto transfronteiriços; agindo assim, mostrou a suscetibilidade do sistema às pressões políticas o que de fato limita a independência na tomada de decisões. Em muitas ocasiões, como na do Complexo Madeira, as decisões já foram tomadas politicamente e os relatórios ambientais são apenas um protocolo. Isso manifestou um claro desrespeito para com os países vizinhos e o desconhecimento dos princípios de precaução e boa vizinhança que regem o Direito Ambiental Internacional e que se encontram estabelecidos na Conferência das Nações Unidas sobre Ambiente Humano(Estocolmo 1972), a Conferência das Nações Unidas sobre Meio Ambiente e Desenvolvimento (ECO - 92) e a Convenção sobre Diversidade Biológica (assinada durante ECO - 92), todos eles convênios assinados e ratificados pelo Brasil. Concordando assim com a afirmação de RIBERA ARISMENDI, 2010, a não consulta aos países vizinhos é uma quebra dos princípios democráticos e demonstra a agressividade da política energética brasileira. 
Este caso deixa claro a inexistência de mecanismos eficientes e vinculantes para avaliar os impactos de megaobras como estas, cujos impactos ultrapassam fronteiras. Foi igualmente evidente a falta de vontade política, de compromisso e desconhecimento, tanto do governo brasileiro quanto do governo boliviano, em aplicar os acordos multilaterais assinados pelos dois países, como o de Estocolmo 72 e Rio 92.

No caso da Rodovia Interoceânica, sua forma de licenciamento por partes limitou a visão clara dos impactos ambientais da rodovia como um todo; por exemplo, nos relatórios dos estudos de impacto ambiental apresentados para o processo de licenciamento da Interoceânica, não são mencionados os impactos ambientais transfronteiriços que poderiam ser causados (e que efetivamente têm ocorrido) ao longo da tripla fronteira Brasil, Peru e Bolívia.

Igualmente nos textos dos relatórios apresentados no Peru, fica clara a influência dos órgãos financiadores como o BM ou a CAF na realização dos EIA como requisito para o financiamento dos projetos. Porém, interesses mais importantes ressaltados na Declaração de Porto Maldonado pelos presidentes de Brasil e Peru, são claramente econômicos, evidenciando um pequeno interesse no componente ambiental, o que ocasiona que muitos dos processos de AIA sejam só protocolares, e os processos de aprovação das obras, como ocorreu no Peru, estejam cheios de irregularidades (INTERSUR CONCESIONES S.A., 2007; WALSH; CONSECIONARIA IIRSA SUR)

Metodologicamente, só foi encontrada a iniciativa da EASE; esta é explícita para avaliar os impactos dos grupos de projetos da IIRSA, que cobrem vários países. Porém, é uma metodologia com foco estratégico, a qual está muito apropriada pela abrangência que propõe, mas o contexto atual dos países sul-americanos não permite uma efetiva aplicação da ferramenta, pois como já foi considerado, existem problemas de base, como a geração, atualização, acesso e o compartilhamento da informação, além do pouco conhecimento e entendimento dos países envolvidos da AAE, que ainda está em etapa de aprimoramento.

A metodologia para a Avaliação de Impactos Ambientais e Sociais com Enfoque Estratégico (EASE) foi desenvolvida pela CAF, à pedido do Comitê Executivo da IIRSA ao Comitê Técnico em 2005. Tal metodologia ficou pronta para aplicação piloto em 2007, e em 2009 foram feitos os ajustes necessários, ou seja, 9 anos após de ter iniciado a proposta da IIRSA, que iníciou formalmente no ano 2000, quando já existiam recursos destinados e em execução. Muitos dos projetos planejados nesta iniciativa já estão em fases avançadas de construção. Isso demonstra que o interesse 
pelas questões ambientais estão ainda em nível muito inferior ao demonstrado pelas questões econômicas, o que faz da metodologia apenas mais um esforço para incluir a temática ambiental em aspectos tão relevantes como a construção de megaobras em lugares de alto impacto ambiental transfronteiriço (IIRSA, 2011a, 2013).

Até o ano 2013, só 3 eixos dos 12 existentes têm aplicação piloto da metodologia, ou seja, ainda não é de fato aplicada a todos os grupos de projetos. Por isso, seu objetivo de ser estratégica e de delinear aspectos ambientais para os grupos de projetos é ineficaz, permitindo que os projetos tenham altos impactos ambientais negativos que sinergicamente podem afetar a toda América do Sul (IIRSA, 2013).

Assim, a EASE é uma metodologia interessante e um esforço das organizações de financiamento, neste caso a CAF, ao incluir o componente ambiental na execução de megaobras de grande influência como as da IIRSA. Porém, existem grandes obstáculos para que possam ser usadas todas as potencialidades da ferramenta de uma maneira efetiva.

O êxito de seu uso radica-se na antecedência com o qual é aplicado. No caso dos projetos da IIRSA, a maioria deles estão em fases avançadas de planificação, execução e operação, onde a maior parte das decisões já têm sido tomadas; sendo assim, a ferramenta não pode influenciar adequadamente a tomada de decisão.

O uso da informação secundária forma parte da base da metodologia, e, por isso, conseguiria ser rápida. Porém, existem graves falências na produção de informação, atualização, sistematização, padronização e acesso dos países sulamericanos, o que faz com que o uso de informação secundária seja difícil e pouco confiável.

Considerando as análises anteriores e o apresentado na tabela 6, tem-se observado que não existe conformidade com os princípios e boas práticas da AIA-T. Institucionalmente, não existe uma estrutura consistente que permita fazer a AIA-T dos projetos em execução e metodologicamente só foi encontrada a metodologia EASE da IIRSA, a qual está em aplicação piloto e em consequência não é de uso generalizado. 


\section{MARCO DE REFERÊNCIA VS. PAÍSES AMAZÔNICOS}

Como visto no decorrer do texto, os princípios básicos para a AIA-T foram estabelecidos pela Conferência da Terra de Estocolmo 1972, cuja declaração foi assinada por 113 países, e pela Rio 92, assinada por mais de 100 países, entre os quais estão todos os países sul-americanos e europeus, que estão de acordo com o que foi exposto e conveniaram a comprometer-se com os princípios ali estabelecidos.

Contudo, apesar da comunidade internacional ter assumido com entusiasmo o compromisso de aplicar ditos acordos, um decênio depois da celebração da Conferência do Rio existia um atraso considerável em sua instrumentação efetiva (embora em conferências posteriores tenham sido referendados os principais princípios da mesma). O progresso tem sido lento pelas dificuldades em conciliar interesses e acordar metas e medidas concretas aceitas por todos (IIRSA, 2011a).

Na figura 18, observa-se como a União Europeia assumiu seu compromisso de maneira específica e concreta ao internalizar o exposto na Convenção de Espoo e o Protocolo de Kiev de maneira vinculante através das diretivas europeias, estabelecendose regras claras para os casos em que são gerados impactos ambientais transfronteiriços, o que gera segurança no atuar.

Nos países amazônicos, este compromisso foi assumido de maneira generalizada e vaga, visto que a maioria dos países em suas normativas especificam que estão dispostos a cumprir os compromissos internacionais assumidos, porém, não especificam como. Em consequência, no caso dos impactos ambientais transfronteiriços, atuam caso a caso, agindo de uma maneira bilateral geralmente, deixando o assunto à discricionariedade dos países envolvidos, sem ter regras claras, ocasionando incertezas na forma de agir. Isto leva a potenciais e graves impactos ambientais, especialmente no momento atual da região, quando estão sendo desenvolvidos projetos em grande escala e que estão gerando impactos ambientais transfronteiriços de grande envergadura, tendo o potencial de afetar sinergicamente toda a região. 
Princípio: Boa vizinhança - Precaução - Notificação - Cooperação internacional Soberania estatal sobre os recursos naturais (Estocolmo,72 e Rio, 92)

União Europeia
Convenção sobre Avaliação de Impactos
Ambientais em contextos transfronteiriços.
(Espoo, 1991)

Protocolo de Avaliação Ambiental Estratégica ao Convênio sobre a Avaliação do Impacto ambiental em um Contexto Transfronteiriço. (Kiev, 2003)

Diretiva Europeia 85/337/CEE

Diretiva Europeia sobre AIA 97/11/EC

Diretiva Europeia sobre AAE 2001/42/EC

Diretiva Europeia 2003/35/EC

Normativas que estabelecem um marco claro em termos processuais para a AIA- T.

\section{Países Amazônicos}

\section{Bolívia}

Regulamento Geral de Gestão Ambiental de 1995.

Regulamentação de Prevenção e Controle Ambiental de 1995.

Brasil

Resolução Nº 237 de 1997.

Lei complementar No 140 de 2011

\section{Colômbia}

Decreto No 2811 DE 1974.

Só são estabelecidos alguns pontos processuais e de responsabilidades para a AIA - T nas normativas de apenas três dos oito países amazônicos.

Figura 18 - Comparação de princípios de AIA - T com Marco de Referencia vs Países Amazônicos.

Isso se reflete de certa maneira nos casos das hidrelétricas do rio Madeira e na Rodovia Interoceânica. No primeiro caso, apesar de haver sérios indícios dos impactos que estas hidrelétricas poderiam causar no território boliviano, as mesmas foram licenciadas ambientalmente e construídas, sob um contexto de irregularidades. Não foram feitos estudos suficientes e atualmente estão causando novamente polêmica pelos impactos que de fato já estão ocorrendo no território boliviano.

No caso da Rodovia Interoceânica, esta foi tratada como pequenos projetos nacionais, tanto no Brasil quanto no Peru, e, por isso, não tem sido feita uma avaliação global dos impactos ambientais de toda a infraestrutura. Isso é uma pequena amostra de como estão sendo contempladas as avaliações ambientais no contexto da IIRSA, onde se executam em uma escala geográfica relativamente limitada aos corredores das vias, o que oferece uma avaliação fragmentada e não permite identificar adequadamente os 
impactos cumulativos e sinérgicos sobre a região como um todo; em consequência, as ações para evitar ou mitigar os impactos resultantes são insuficientes (GAMBOA; GUDYNAS, 2013)

Como foi descrito, esta forma generalizada e vaga com a qual os países amazônicos assumiram estes compromissos, estão de fato ocasionando impactos ambientais em um nível além do transfronteiriço - em um nível regional.

Estes comportamentos dependem muito do contexto de cada região. Assim, para levar a cabo uma AIA-T, é necessário ter vários fatores em conta, como as diferentes estruturas jurídicas e normativas, sistemas políticos, contextos socioeconômicos e ambientais específicos; porém o marco geral normalmente é similar. Esta é uma das grandes vantagens da Convenção de Espoo, já que proporciona um marco geral para a AIA-T (CASSAR; BRUCH, 2003)

O caso da União Europeia contextualmente é diferente: tem um processo de integração avançado e baseia-se nos princípios do Estado de direito, a saber, toda a sua ação deriva de tratados voluntária e democraticamente aprovados por todos os EstadosMembros. O caráter único da UE resulta do fato de que, não obstante são todos soberanos e independentes, estes países congregaram parte da sua «soberania»para ganhar força. Entre as vantagens deste sistema está a repartição mais equitativa dos ganhos e das perdas, pois o tipo de integração que tem promove a busca do bem-comum acima do particular (COMISSÃO EUROPEIA; DIREÇÃO-GERAL DA COMUNICAÇÃO, 2013). Está é a razão pela qual, através das diretivas europeias, temse dado à Convenção de Espoo um caráter vinculante e estruturado que permite, além do cumprimento dos requisitos, fazer seguimentos que conduzem à sua melhora contínua por meio de sua própria experiência. Isso permite que a União Europeia seja um referente em muitas questões, entre estas a AIA-T.

Os países da América do Sul têm diferenças significativas com a União Europeia e não têm um processo de integração tão sólido, pelo que é notória a relação de quem ganha em quem perde com as decisões que são tomadas. Por exemplo, no caso do rio Madeira, é muito claro que ganha a economia brasileira, por estar obtendo a energia necessária para a sua produção, mas as consequências ambientais são pagas pelos países vizinhos e pela população brasileira localizada nas regiões afetadas. Mas isso não é um impedimento para a aplicação de processos de AIA-T, pois segundo o assinalado por CASSAR; BRUCH, 2003 ante as notáveis variedades de enfoques 
internacionais, regulamentos, normas e esforços para proteger contra a discriminação através das fronteiras internacionais, a maneira mais eficiente de avançar na interpretação e aplicação dos princípios da AIA-T em tão diversas circunstâncias é abraçar essa diversidade e adaptar as disposições da AIA-T em questão às circunstâncias específicas que são enfrentadas.

Assim, os processos de AIA-T podem adaptar-se às circunstâncias, mas de qualquer forma é muito importante sua institucionalização, tal como é ressaltado por BASTMEIJER; KOIVUROVA, 2008b é de grande importância para o bom funcionamento dum sistema de AIA-T que haja organismos, em nível internacional, encarregados de desenvolver o sistema e supervisionar seu cumprimento.

$\mathrm{Na}$ América do Sul, este é um fator especialmente importante, pois os governos estão mudando constantemente em termos de ideologia, pessoal e políticas, razão pela qual é importante um documento juridicamente vinculante e uma comissão internacional mista para sustentar uma ferramenta como a AIA-T

A AIA-T nos países sul-americanos é necessária por conta dos processos de integração atuais, mas, sobretudo, pelos projetos de infraestrutura e de exploração de recursos naturais, que cada vez são em maior escala e frequentemente seus impactos ambientais estão atravessando fronteiras. É importante ter uma ferramenta de AIA-T diferente dos processos de AIA nacionais, já que segundo BASTMEIJER; KOIVUROVA, 2008b, um sistema de AIA-T não é somente um possível componente dos sistemas de AIA nacionais, pois tem um status diferente baseado num acordo internacional para se ter em conta os impactos ambientais transfronteiriços.

Assim, fica clara a necessidade de contar com ferramentas de AIA-T na América do Sul, para o que é necessário estudar as melhores opções para instaurar esse tipo de ferramentas na região. 


\section{CONCLUSÕES.}

Com o objetivo de descrever as características institucionais e metodológicas da AIA-T em países da região amazônica e avaliar sua conformidade com os princípios e as boas práticas da AIA-T em nível mundial, neste trabalho foram levantados os aspectos gerais do instrumento, os marcos institucionais e metodológicos em nível mundial, assim como o marco institucional e metodológico tanto dos países amazônicos quanto dos órgãos sub-regionais atuantes na região.

Foi identificada no âmbito mundial a União Europeia como marco de referência, por ter um quadro normativo e metodológico claro e explícito, além de ter um uso recorrente desta ferramenta com altos índices de sucesso.

A descrição do marco institucional foi baseada na análise dos quadros institucionais dos 8 países amazônicos referentes às normativas de AIA e o gerenciamento das temáticas ambientais em nível internacional, além do marco institucional referente ao componente ambiental dos órgãos sub-regionais atuantes na região (UNASUL - OTCA - CAN - MERCOSUL). Assim, encontrou-se que tanto os países sul-americanos quanto os órgãos sub-regionais carecem de um conjunto claro de requisitos jurídicos e institucionais sobre como conduzir, analisar e finalizar a AIA-T.

Para conseguir entender e assim descrever as características metodológicas do gerenciamento dos impactos transfronteiriços, foram enviados questionários aos escritórios encarregados da gestão ambiental e do gerenciamento dos assuntos ambientais em nível internacional nos 8 países amazônicos, objetivando o conhecimento desde a ótica das pessoas que lidam com estes aspectos diariamente, de como são gerenciados os impactos ambientais transfronteiriços na prática, além de analisar os estudos de caso do Complexo Hidrelétrico do Rio Madeira e da Rodovia Interoceânica. Além disso, foram analisados os projetos da IIRSA para identificar como estas megaobras, que em sua maioria abarcam mais de um país, estão gerenciando seus impactos.

Desta análise, foi identificado que não existe uma estrutura processual clara e completa em nenhum dos 8 países amazônicos; só a Bolívia, Brasil e Colômbia têm algumas anotações em suas normas, mas não suficientemente claras e completas como para orientar uma AIA-T, o que deixa o gerenciamento deste tipo de impactos à discricionariedade dos países envolvidos. Quanto aos projetos da IIRSA no marco da 
UNASUL, foi encontrada a metodologia EASE. Esta metodologia representa uma iniciativa interessante para avaliar os impactos ambientais dos megaprojetos propostos pela IIRSA desde uma perspectiva ampla e não limitada pelas fronteiras. Além disso, seu foco estratégico ajudaria a orientar a tomada de decisões desde as fases iniciais, porém, sua aplicação pode ser pouco efetiva nas condições atuais, por conta das limitações nos países sul-americanos em termos de entendimento da AAE, de geração de informação base, de harmonização na apresentação dos dados e de mecanismos efetivos de participação cidadã.

Finalmente, baseado nos resultados anteriores, foi analisada a conformidade destas características institucionais e metodológicas da AIA-T com os princípios estabelecidos em Estocolmo 72, Rio 92 e o marco de referência, que é a União Europeia. Encontrou-se que não existe conformidade com estes princípios e nem com as boas práticas de AIA-T, pois os casos estudados não representam uma AIA-T.

Portanto, estas análises permitiram cumprir com os objetivos propostos, porém, aspectos como a falta de participação na resolução dos questionários limitaram o aprofundamento na prática do instrumento.

É importante ressaltar que a nova expressão da exploração dos recursos naturais em nível regional, assim como as megaobras de infraestrutura que estão sendo adiantadas na América do Sul, torna imprescindível a necessidade de se ter um conjunto claro de requisitos jurídicos, processuais e institucionais, para o efetivo desenvolvimento das Avaliações de Impacto Ambiental Transfronteiriço, de modo que esta ferramenta seja parte integral dos procedimentos de tomada de decisões que envolvam os países amazônicos, a fim de assegurar o cumprimento dos compromissos assumidos internacionalmente, tanto em Estocolmo 72 e Rio 92 quanto aqueles referentes à proteção do ecossistema amazônico.

Sendo assim, seria interessante para estudos futuros analisar como este instrumento poderia ser inserido no contexto sul-americano. 


\section{REFERÊNCIAS BIBLIOGRÁFICAS}

AIDA. Grandes Represas en América ¿Peor el remedio que la enfermedad? Principales consecuencias ambientales $\mathbf{y}$ en los derechos humanos y posibles alternativas. Asociación Interamericana para la Defensa del Ambiente, AIDA, 2009.

ALBRECHT, E. Implementing the Espoo Convention in transboundary EIA between Germany and Poland. Environmental Impact Assessment Review, v. 28, n. 6, p. 359365, 2008.2 Disponível em: <http://linkinghub.elsevier.com/retrieve/pii/S0195925507001308>. Acesso em: 18/11/2013.

AMIGOS DA TERRA; INTERNATIONAL RIVERS NETWORK. ESTUDOS NÃO CONFIÁ VEIS: 30 FALHAS NO EIA-RIMA DO RIO MADEIRA. 2006.

ANDER - EGG, E. Técnicas de investigación Social. Buenos Aires - Argentina: Lumen, 1995.

BALVIN, D.; PATRON, P. Carretera Interoceánica Sur-Consideraciones para su aprovechamiento sostenible. Moquegua, Perú, 2006.

BASES PARA UNA VISION COMUN DE LA CUENCA DEL RIO AMAZONAS. .otca.org.br, $\quad$ p. $1-136 . \quad$ Disponível <http://www.otca.org.br/gefam/publico/_arquivos/File/informe parcial 02 CIPGEFA.pdf $>$. Acesso em: 24/9/2013.

BASTMEIJER, K.; KOIVUROVA, T. Transboundary Environmental Impact Assessment: An Introduction. Theory and Practice of Transboundary Environmental Impact Assessment. p.26, 2008a. Boston: Brill/Martinus Nijhoff. Disponível em: 〈http://books.google.com.br/books?id=d2FID2fDWzwC >. Acesso em: 8/9/2013.

BASTMEIJER, K.; KOIVUROVA, T. Theory and practice of transboundary environmental impact assessment. 2008b.

BERMANN, C.; WITTMANN, D.; HERNÁNDEZ, F. DEL M.; RODRIGUES, L. A. USINAS HIDRELÉTRICAS NA AMAZÔNIA - O FUTURO SOB AS ÁGUAS. Seminário Políticas Públicas e obras de infraestrutura na Amazônia. Anais... p.1-37, 2010. Brasilia - DF, Brasil: Anais Cenários e desafios para a governança socioambiental. Disponível em: <http://www.inesc.org.br/biblioteca/publicacoes/textospara-discussao/Celio Bermann - Hidreletricas na Amazonia.pdf/at_download/file.>. .

BINA, O. A critical review of the dominant lines of argumentation on the need for strategic environmental assessment. Environmental Impact Assessment Review, v. 27, p. 585-606, 2007. Disponível em: <http://www.sciencedirect.com/science/article/pii/S0195925507000698>. Acesso em: 8/9/2013. 
BOER, J. DE. Bilateral agreements for the application of the un-ece convention on eia in a transboundary context. Environmental Impact Assessment Review, v. 9255, n. ipc 660, p. 85-98, 1999. Disponível em: <http://www.sciencedirect.com/science/article/pii/S0195925598000341>. Acesso em: 18/11/2013.

BOLIVIA. LEY Nro. 1333, de 27 de abril de 1992. Tiene por objeto la protección y conservación del medio ambiente y los recursos naturales, regulando las acciones del hombre con relación a la naturaleza e promoviendo el desarrollo sostenivle con la finalidad de mej. , 1992. La Paz - Bolivia: Congreso Nacional.

BOLIVIA. Reglamento de Prevención y Control Ambiental, 8 de diciembre de 1995. La presente disposición legal reglamenta la Ley del Medio Ambiente $\mathrm{N}^{\mathrm{o}} 1333$ de 27 de abril de 1992, en lo referente a Evaluación de Impacto Ambiental (EIA) y Control de Calidad Ambiental. ,1995. La Paz - Bolivia: DeveNet.net. Disponível em: $<$ http://www.estrucplan.com.ar/Producciones/entrega.asp?IdEntrega=1552 http://www.estrucplan.com.ar/Producciones/entrega.asp?IdEntrega=1553>. .

BOLIVIA. DECRETO SUPREMO N 28389 DE 6 DE OCTUBRE DE 2005. Declarar de interés y prioridad nacional la definición de una politica nacional en materia de aprovechamiento integral de las cuencas hidrográficas del país. ,2005. La Paz - Bolivia, Bolivia. Disponível em: <http://www.ae.gob.bo/userfiles/file/pdf/ml/28389.pdf>. .

BRASIL. Lei Federal Nº $\mathrm{N}^{\mathrm{o}}$ 6.938, de 31 de agosto de 1981. Dispõe sobre a Política Nacional do Meio Ambiente, seus fins e mecanismos de formulação e aplicação, e dá outras providências. ,1981. Brasilia - DF, Brasil.

BRASIL. Decreto $N^{\circ}$ 6.101, de 26 de abril de 2007. Aprova a Estrutura Regimental e o Quadro Demonstrativo dos Cargos em Comissão e das Funções Gratificadas do Ministério do Meio Ambiente, e dá outras providências. ,2007. Brasilia - DF, Brasil: DOU de 27.4.2007.

BRASIL. LEI COMPLEMENTAR $\mathrm{N}^{0}$ 140, DE 8 DE DEZEMBRO DE 2011. Fixa normas, nos termos dos incisos III, VI e VII do caput e do parágrafo único do art. 23 da Constituição Federal, para a cooperação entre a União, os Estados, o Distrito Federal e os Municípios nas açõe. ,2011. Brasilia - DF, Brasil: DOU DE 09-12-2011.

BRASIL; CONAMA. RESOLUÇÃO CONAMA N N 001, de 23 de janeiro de 1986. ,1986. Brasilia - DF, Brasil, Brasil: D. O . U de 17 /2/86. Disponível em: <http://www.mma.gov.br/port/conama/res/res86/res0186.html>. .

BRASIL; CONAMA. RESOLUÇÃO Nº 237, DE 19 DE DEZEMBRO DE 1997. ,1997. Brasilia - DF, Brasil.

BRASIL; IBAMA. Parecer Técnico N 014/2007 - COHID/CGENE/DILIC/IBAMA. Brasilia - DF, Brasil, 2007.

BRAVO ORELlanA, S. Carretera Interoceánica Sur del Peru. Retos e innovación. Bogotá - Colombia, 2013. 
BRUCH, C.; NAKAYAMA, M.; TROELL, J.; GOLDMAN, L.; MREMA, E. M. Assessing the assessments: improving methodologies for impact assessment in transboundary watercourses. Impact Assessment and Project Appraisal, v. 26, n. 4, p. 239-251, 2008. Disponível em: <http://www.tandfonline.com/doi/abs/10.3152/146155108X366022>. Acesso em: 8/9/2013.

CAF. Metodología de Evaluación Ambiental y Social con Enfoque Estratégico EASE- IIRSA. Caracas - Venezuela: IIRSA, 2009.

CAF. Metodología de Evaluación Ambiental y Social con Enfoque Estratégico EASE -IIRSA. Bogotá: Corporación Andina de Fomento - CAF, 2010.

CAF. Aplicación Metodología EASE-IIRSA. Grupo 6 de proyectos del eje Andino: Conexión Colombia - Ecuador II. Bogotá - Colombia: CAF, 2011.

CAN. AGENDA AMBIENTAL ANDINA 2012 - 2016. Lima - Peru, 2012.

CASSAR, A. Z.; BRUCH, C. Transbounday Environmental Impact Assessment in international watercourse management. New York University Environmental Law Journal, v. 12, p. 169 - 244, 2003. Disponível em: $<$ http://www.heinonline.org/HOL/Page?page=169\&handle=hein.journals\%2Fnyuev12\& collection=journals\#177>. .

CEDEÑO, M. Assessment of Transboundary Environmental Impacts in Developing Countries: The Case of Central America. In: K. Bastmeijer; T. Koivurova (Eds.); Theory and Practice of Transboundary Environmental Impact Assessment. p.391, 2008. Leiden: Martinus Nijhoff Publishers.

CEPAL; UNASUR. UNASUR un espacio de desarrollo y cooperación por construir. Santiago de Chile, 2011.

COBRAPE, C. B. DE P. E E. RELATÓRIO DE ANÁLISE DO CONTEÚDO DOS ESTUDOS DE IMPACTO AMBIENTAL (EIA) E DO RELATÓRIO DE IMPACTO AMBIENTAL (RIMA) DOS APROVEITAMENTOS HIDRELÉTRICOS DE SANTO ANTONIO E JIRAU, NO RIO MADEIRA, ESTADO DE RONDÔNIA. 2006.

COLOMBIA. DECRETO 2811 DEL 18 DE DICIEMBRE DE 1974. Por el cual se dicta el Código Nacional de Recursos Naturales Renovables y de Protección al Medio Ambiente. ,1974. Bogotá, D.C - Colombia: Presidencia de la República.

COLOMBIA. CONSTITUCION POLITICA DE COLOMBIA. ,1991. Bogotá, D.C Colombia: Presidencia de la República, Secretaria Jurídica.

COLOMBIA. LEY 191 DE 1995. Por medio de la cual se dictan disposiciones sobre Zonas de Frontera. ,1995. Bogotá - Colombia: Congreso de Colombia.

COLOMBIA; CONGRESO. LEY 99 DE 1993. por la cual se crea el Ministerio del Medio Ambiente, se reordena el Sector Público encargado de la gestión y conservación 
del medio ambiente y los recursos naturales renovables, se organiza el Sistema Nacional Ambiental, SINA, y se dictan. ,1993. Bogotá - Colombia: Congreso de Colombia.

COLOMBIA; MINISTERIO DE AMBIENTE, V. Y D. T. Política de Gestión Ambiental Urbana. ,2008. Bogotá, D.C - Colombia: Ministerio de Ambiente, Vivienda y Desarrollo Territorial.

COMISIÓN ECONÓMICA PARA EUROPA. Convenio sobre la evaluación del impacto ambiental en un contexto transfronterizo. ,1991. Espoo, Finlandia, Espoo Finlandia: http://www.unece.org. Disponível em: $<$ http://www.unece.org/fileadmin/DAM/env/eia/documents/legaltexts/conventiontextsp anish.pdf $>$. .

COMISSÃO EUROPEIA; DIREÇÃO-GERAL DA COMUNICAÇÃO. Como funciona a União Europeia. Luxemburgo: União Europeia, 2013.

CONAMA. Aproveitamento hidrelétrico do rio Madeira. 2007. Brasil: Ministerio do Meio Ambiente. Disponível em: <http://www.mma.gov.br/port/conama/mocoes/mocao07/mocao08307.pdf>. .

CONNELLY, R. G. THE UN CONVENTION ON EIA IN A TRANSBOUNDARY CONTEXT : A HISTORICAL PERSPECTIVE. Environmental Impact Assessment Review, v. 19, n. 98, p. 37-46, 1999.

COSIPLAN. DECLARACIÓN DE LAS MINISTRAS Y MINISTROS DEL CONSEJO SURAMERICANO DE INFRAESTRUCTURA Y PLANEAMIENTO. Brasilia - DF, Brasil, 2011.

\section{COSIPLAN. PLAN DE ACCIÓN ESTRATÉGICO 2012-2022. 2012.}

CRAIDE, S. Bolívia e Brasil vão analisar impacto de usinas no rio Madeira em inundações na parte boliviana da Amazônia. Carbono Brasil, p. 2-3, 2014. Disponível em: <http://www.institutocarbonobrasil.org.br/noticias3/noticia=736539>. .

CRAIK, N. Transboundary Environmental Impact Assessment in North America: Obstacles and Opportunities. In: T. Koivurova; K. Bastmeijer (Eds.); Theory and Practice of Transboundary Environmental Impact Assessment. p.391, 2008. Leiden: Martinus Nijhoff Publishers.

DIDOB. Una región en construcción UNASUR y la integración en América del Sur. Fundación ed. Barcelona - España: Romanya Valls, 2010.

DIJCK, P. VAN. The Impact of the IIRSA Road Infrastructure programme on Amazonia. Routledge, 2013.

DOUROJEANNI, M. J. Estudio de caso sobre la carretera Interoceánica en la amazonía sur del Perú. 2006. 
ECOlOGIA, A. Y.; DAVID, J.; CRUZ, P.; TOMAS, A.; SIERRALTA, C. “ COMISION DE PUEBLOS ANDINOS , AMAZONICOS , AFROPERUANOS ,. ,2008.

ECUADOR. Constitución del ecuador. . Quito - Ecuador: Asamblea Constituyente.

ESPINOZA, G. Metodología EASE - Aspectos conceptuales y resultados de su aplicación: El caso delGrupo 2 de proyectos del eje del sur de IIRSA. 2013.

ESPINOZA, G.; GAVIÑO NOVILLO, J. M.; VALDÉS, J.; PARIMBELLI, M.; SANTIBAÑEZ, D. Lecciones Aprendidas con la Aplicación de la Metodología de Evaluación Ambiental y Social con Enfoque Estratégico - EASE- IIRSA. Buenos Aires, 2010.

EULER, A. M. .; SANTOS, M. C. DOS. Políticas Energéticas en la Amazonía: Análisis del Complejo Río Madeira, Rondonia. worldagroforestry.org. p.29, 2009. Rondonia. Disponível em: <http://www.worldagroforestry.org/latinamerica/sites/worldagroforestry.org.latinameric a/files/politicas_energeticas_amazonia.pdf>. Acesso em: 13/3/2014.

FEARNSIDE, P. . Viewpoint-Brazil's Madeira River Dams: A Setback for Environmental Policy in Amazonian Development. Water Alternatives, v. 7, n. February, p. 154-167, 2014. Disponível em: <http://www.wateralternatives.org/index.php?option=com_content\&task=view\&id=59\&Itemid=1 $>$.

Acesso em: 12/3/2014.

FEARNSIDE, P. M.; BARBOSA, R. I. Political benefits as barriers to assessment of environmental costs in Brazil's Amazonian development planning: The example of the Jatapu Dam in Roraima. Environmental Management, v. 20, n. 5, p. 615-630, 1996. Disponível em: <http://link.springer.com/10.1007/BF01204135>. .

FERREIRA, R. M.; BETENCOURT E FREITAS, V. M. A proteção ao meio ambiente em nível internacional através da avaliação dos impactos ambientais num contexto transfronteiriço. Fronteiras, v. 1, n. 1, p. 26-39, 2012. Disponível em: <http://revistas.unievangelica.edu.br/index.php/fronteiras/article/download/395/394> . .

FOBOMADE; CGIAB. El Norte Amazónico de Bolivia y el Complejo del Río Madera. La Paz - Bolivia, 2007.

FRANCO NETO, D.; OLIVEIRA AOKI, T. DE. O conflito do Rio Madeira entre Brasil e Bolívia e a busca de sua solução por meio do Direito Internacional. Revista Eletronica de Direito Internacional, v. 5, n. 1981-9439, p. 132-156, 2009. Disponível em: <http://www.cedin.com.br/revistaeletronica/volume5/>. .

FURNAS; ODEBRECHT; LEME. Estudo de Impacto Ambiental - EIA, Hidrelectrica Rio Madeira - Tomo A - Volume 1. 2007a.

FURNAS; ODEBRECHT; LEME. AVALIAÇÃO DO "RELATÓRIO DE ANÁLISE DO CONTEÚDO DO EIARIMA DOS APROVEITAMENTOS 
HIDRELÉTRICOS DE SANTO ANTÔNIO E JIRAU, NO RIO MADEIRA."2007b.

FURNAS; ODEBRECHT; LEME. Estudo de Impacto Ambiental - EIA, Hidrelectrica Rio Madeira - Tomo B - Volume 1A/8. 2007c.

GAMARRA, L. F. Carretera IIRSA Sur símbolo de unión entre dos países LaRepublica. La Republica.Pe, 5. Jun. 2013. Lima - Peru. Disponível em: $<$ http://www.larepublica.pe/05-06-2013/carretera-iirsa-sur-simbolo-de-union-entre-dospaises $>$. .

GAMBOA, C.; GUDYNAS, E. Ambiente y energía en la Amazonia. Gobernanza, Rio+20 y economía verde en discusión - Panel Internacional de Ambiente y Energía en la Amazonia. ,2013. Lima - Peru: DAR - CLAES. Disponível em: $<$ http://www.amazonia-

andina.org/sites/default/files/ambiente_y_energia_en_la_amazonia_dar.pdf $>$. .

GEOSUR. IIRSA EJES. Disponível em:

<http://www.geosur.info/geosur/iirsa/pdf/es/ejes.jpg>. Acesso em: 2/6/2014a.

GEOSUR. IIRSA Peru - Brasil - Bolivia. Disponível em: <http://www.geosur.info/geosur/iirsa/pdf/es/g3_pbb.jpg>. Acesso em: 2/6/2014b.

GEOSUR. IIRSA Andino. Disponível em:

<http://www.geosur.info/geosur/iirsa/pdf/es/g6_and.jpg>. Acesso em: 2/6/2014c.

GEOSUR. IIRSA SUR. Disponível em:

<http://www.geosur.info/geosur/iirsa/pdf/es/g2_sur.jpg>. .

GREENPEACE. Mapa Amazonia. Disponível em: <http://www.greenpeace.org/brasil/global/brasil/image/2010/5/mapa_amazonia.jpg>. Acesso em: 6/3/2014.

GTZ/FUNDECO/IE. Estrategia Regional de Biodiversidad para los Países del Trópico Andino: Comercio y valoración Impacto de Megaproyectos de Infraestructura. La Paz - Bolivia, 2002.

GTZ/FUNDECO/IE; CAN; BID. Estrategia Regional de Biodiversidad para los Países del Trópico Andino: Conservación de Ecosistemas Transfronterizos e Protección e Recuperación de Especies Amenazadas. Lima - Peru, 2001.

GUDYNAS, E. Conflictos ambientales en zonas de frontera y gestión ambiental en América del Sur. Gestión Ambiental, v. 13, n. 1, p. 1-19, 2007. Disponível em: $<$ http://scholar.google.com/scholar?hl=en\&btnG=Search\&q=intitle:CONFLICTOS+A MBIENTALES+EN+ZONAS+DE+FRONTERA+Y+GESTI $>\mathrm{N}+\mathrm{AMBIENTAL+EN+}$ AM?RICA+DEL+SUR\#0>. Acesso em: 8/9/2013.

GUYANA. CONSTITUTION OF THE COOPERATIVE REPUBLIC OF GUYANA ACT. ,1980. Georgetown - Guyana. 
GUYANA. ENVIRONMENTAL PROTECTION ACT. ,1996. Georgetown - Guyana.

HECK FRANCO, C. Análisis legal del “ Acuerdo entre el Gobierno de la República del Perú y el Gobierno de la República Federativa del Brasil para el suministro de electricidad al Perú y la exportación de excedentes al Brasil ."Serie de politica y derecho ambiental, p. 36, Feb. 2011. Lima - Peru. Disponível em: $<$ http://www.actualidadambiental.pe/wp-

content/uploads/2011/02/serie_politica_21.pdf >. .

HILDÉN, M.; FURMAN, E. Assessment across borders: Stumbling blocks and options in the practical implementation of the Espoo Convention. Environmental Impact Assessment Review, v. 21, p. 537-551, 2001. Disponível em: <http://www.sciencedirect.com/science/article/pii/S0195925501000889>. Acesso em: 18/11/2013.

IAIA. Strategic environmental assessment. 2002. Disponível em: $<$ http://www.iaia.org/publicdocuments/special-

publications/sp1.pdf?AspxAutoDetectCookieSupport=1>. .

IAIA; IEA. Principios da melhor prática em avaliacao do impacto ambiental. ,1999. Disponível em: <www.iaia.org>. .

IIRSA. Agenda de Implementación Consensuada 2005 - 2010. 2010a.

IIRSA. Evaluación Ambiental y Social con enfoque estratégico (EASE) - Grupo 2 eje del sur: Circuito Turístico Binacional. Zona de los Lagos (Argentina y Chile). Buenos Aires - Santiago, 2010b.

IIRSA. IIRSA 10 años despues: sus logros y desafíos. 1st ed. Buenos Aires Argentina, 2011a.

IIRSA. Agenda de Proyectos Prioritarios de Integración. 2011 b.

IIRSA. Aplicación de la Metodología EASE al Proyecto Binacional de Transporte Multimodal en el Sistema Laguna Merín-Lagõa dos Patos. ,2013. Disponível em: <http://www.iirsa.org/admin_iirsa_web/Uploads/Documents/ease_santiago13_anexo3_ aplicacion_laguna_merin_dos_patos.pdf $>$. .

IIRSA. IIRSA Laguna Merín - Lagoa dos Patos. Disponível em: <http://www.iirsa.org/admin_iirsa_web/Uploads/Documents/ease_santiago13_anexo3_ aplicacion_laguna_merin_dos_patos.pdf $>$. Acesso em: 2/6/2014.

IIRSA; EASE. Acceso y gestión de la Información: eje del sur, grupo 2, circuito turístico binacional de la Zona de los Lagos (Argentina - Chile). ,2010. Disponível em: <http://www.iirsa.org/admin_iirsa_web/Uploads/Documents/ease_lima10_ppt_parimbel li.pdf $>$. .

INTERSUR CONCESIONES S.A. ESTUDIO DE IMPACTO AMBIENTAL CORREDOR VIAL INTEROCEANICO SUR, PERÚ - BRASIL , TRAMO 04: 
AZANGARO - PTE . INAMBARI ( II y III Etapa de Construcción ). ,2007. Disponível em: 〈https://www.mtc.gob.pe/portal/transportes/asuntos/proyectos/pvis-tramo_4.htm〉. .

ISAKSSON, K.; STORBJÖRK, S. Strategy making and power in environmental assessments. Lessons from the establishment of an out-of-town shopping centre in Västerås, Sweden. Environmental Impact Assessment Review, v. 34, p. 65-73, 2012. Disponível em: 〈http://linkinghub.elsevier.com/retrieve/pii/S0195925512000029〉. Acesso em: 8/9/2013.

KIS MADRID, C.; HICKEY, G. M.; BOUCHARD, M. A. Strategic Environmental Assessment Effectiveness and the Initiative for the Integration of Regional Infrastructure in South America (Iirsa): a Multiple Case Review. Journal of Environmental Assessment Policy and Management, v. 13, n. 04, p. 515-540, 2011. Disponível em: <http://www.worldscientific.com/doi/abs/10.1142/S1464333211003997>. Acesso em: 8/9/2013.

KNOX, J. H. The Myth and Reality of Transboundary Environmental Impact Assessment. The American Journal of International Law, v. 96, n. 2, p. 291-319, 2002. Disponível em: <http://www.jstor.org/stable/2693925>. .

KOIVUROVA, T.; POLONEN, I. Transboundary environmental impact assessment in the case of the Baltic Sea gas pipeline. ... Journal of Marine and Coastal Law, v. 25, n. $2,2010.2$ Disponível em: $<$ http://www.ingentaconnect.com/content/mnp/estu/2010/00000025/00000002/art00001 >. Acesso em: 18/11/2013.

KOYANO, M. The significance of the Convention on Environmental Impact Assessment in a Transboundary Context (Espoo Convention) in international environmental law: examining the implications of the Danube Delta case. Impact Assessment and Project Appraisal, v. 26, n. 4, p. 299-314, 2008. Disponível em: <http://www.tandfonline.com/doi/abs/10.3152/146155108X391600>. Acesso em: $11 / 11 / 2013$.

LOBOS, V.; PARTIDARIO, M. Theory versus practice in Strategic Environmental Assessment (SEA). Environmental Impact Assessment Review, v. 48, p. 34-46, 2014. Elsevier Inc. Disponível em: 〈http://linkinghub.elsevier.com/retrieve/pii/S0195925514000389>. Acesso em: 4/9/2014.

MACHADO, A. Justiça manda hidrelétricas do Madeira refazerem estudos de impacto ambiental em Rondônia. blog Amazônia/Terra, p. 2-3, 2014. Disponível em: $<$ http://terramagazine.terra.com.br/blogdaamazonia/blog/2014/03/11/justica-mandahidreletricas-do-madeira-refazerem-estudos-de-impacto-ambiental-em-rondonia/>. .

MARC DOUROJEANNI; BARANDIARÁN, A.; DOUROJEANNI, D. Amazonía Peruana en 2021. Peru: ProNaturaleza - Fundación Peruaa para la Conservación de la Naturaleza, 2009. 
MARSDEN, S. The Espoo Convention and Strategic Environmental Assessment Protocol in the European Union: Implementation, Compliance, Enforcement and Reform PROTOCOL IN THE EU BY. RECIEL - Review of European Community \& international Environmental Law, v. 20, n. May 2003, p. 267-276, 2011a. Disponível em: <http://onlinelibrary.wiley.com/doi/10.1111/j.14679388.2011.00729.x/pdf>. .

MARSDEN, S. Assessment of transboundary environmental effects in the Pearl River Delta Region: Is there a role for strategic environmental assessment? Environmental Impact Assessment Review, v. 31, n. 6, p. 593-601, 2011b. Elsevier Inc. Disponível em: <http://linkinghub.elsevier.com/retrieve/pii/S0195925510000636>. Acesso em: 8/9/2013.

MARSDEN, S.; KOIVUROVA, T. Transboundary Environmental Impact Assessment in the European Union:The Espoo Convention and its Kiev Protocol on Strategic Environmental Assessment. I ed. London - New York: earthscan, 2011.

MEGO, A. Las Represas del Rio Madera. Noticias Aliadas, 8. May. 2008. Disponível em: <http://www.comunicacionesaliadas.org/articles.asp?item=1\&art=5614>. .

MERCOSUR. Acuerdo marco sobre medio ambiente del mercosur. ,2001. Asunción Paraguay.

MERCOSUR. Medio Ambiente en el Mercosur. Montevideo - Uruguay, 2006.

MERCOSUR. Recopilación Normativa - Fondo para la convergencia estructural del MERCOSUR. Montevideo - Uruguay, 2009.

MERCOSUR; PNUMA; CLAES. GEO MERCOSUR. 2008.

MOLANO CRUZ, M. Entrevista ao Asesor - Comisiones de Vecindad y Organismos Subregionales Fronterizos. ,2013. Bogotá - Colombia.

NORD STREAM. Nord Stream pipeline. Disponível em: <http://www.nordstream.com/press-info/images/nord-stream-pipeline-in-a transboundary-context-withlegend-2931/?page $=2>$. .

ODG; CÁTEDRA UNESCO DE SOSTENIBILITAT. El "complejo del río madera" : Un caso de anticooperación española. 2010.

OLIVEIRA, A. DE; BURSZTYN, M. Avaliação de impacto ambiental de políticas públicas. Revista Internacional de Desenvolvimento Local, v. 2, n. 3, p. 45-56, 2001. Disponível em: <http://www3.ucdb.br/mestrados/RevistaInteracoes/n3_aparecida_marcel.pdf>. Acesso em: 24/9/2013.

ONU. DECLARACIÓN DE LA CONFERENCIA DE LAS NACIONES UNIDAS SOBRE EL MEDIO HUMANO. ,1972. Disponível em: <http://www.ambiente.gov.ar/infotecaea/descargas/estocolmo01.pdf>. . 
ORGANIZA, A. Seminário Latino Americano de Avaliação Ambiental Estratégica A criação da OTCA : ,2006.

OTCA. La Amazonia sin Mitos. Secretaría ed. 1994.

OTCA. Plan Estratégico 2004 - 2012. 2004.

OTCA. AGENDA ESTRATÉGICA DE COOPERACIÓN AMAZÓNICA. Aprobada en la X Reunión de Ministros de Relaciones Exteriores del TCA. ,2010. Brasilia - DF, Brasil. Disponível em: <www.OTCA.info>. .

OTCA. Oportunidades de cooperación en la región amazónica. Brasilia - DF, Brasil, 2012a.

OTCA. Manejo integrado y sostenible de los recursos hídricos transfronterizos de la cuenca del río Amazonas, considerando la variabilidad y el cambio climático. ,2012b.

OTCA. Base jurídica del tratado de cooperación amazónica. Actualización Resumida. Brasilia - DF, Brasil, 2013.

OTCA. La OTCA - miembros. Disponível em: <http://otca.info/portal/paisesmembros.php? $\mathrm{p}=$ otca\&id $=4>$. .

PARTIDÁRIO, M. R. Scales and associated data - What is enough for SEA needs? Environmental Impact Assessment Review, v. 27, n. 5, p. 460-478, 2007. Disponível em: <http://linkinghub.elsevier.com/retrieve/pii/S0195925507000182>. Acesso em: 8/9/2013.

PAUTRAT, L.; CHE PIU, H.; SAMANIEGO, C.; TORRES, P. Sistematización y mapeo de actores en los procesos de deforestación en los ejes iirsa norte y sur del perú. Lima - Peru, 2009.

PERU; MINISTERIO DEL AMBIENTE. Compendio de la legislación ambiental peruana. Volumen I. Marco Normativo General. Lima - Peru: Ministerio del Ambiente, 2010a.

PERU; MINISTERIO DEL AMBIENTE. Compendio de la legislación Ambiental Peruana. Volumen III. Politica e Instrumentos de Gestión Ambiental. Dirección ed. Lima - Peru: Ministerio del Ambiente, 2010b.

PERU; MINISTERIO DEL AMBIENTE. Compendio de la legislación ambiental peruana. Volumen II. Institucionalidad y Gestión Ambiental. Dirección ed. Lima Peru: Ministerio del Ambiente, 2010c.

PERZ, S.; CARVALHO, L. A.; HURTADO, J. C.; et al. Impacts of Paving the interoceanic highway in the tri-national MAP frontier: Results from household socioeconomic surveys. ,2010.

PERZ, S. G.; CABRERA, L.; CARVALHO, L. A.; et al. Regional integration and local change: road paving, community connectivity, and social-ecological resilience in a tri- 
national frontier, southwestern Amazonia. Regional Environmental Change, v. 12, n. 1, p. 35-53, 2011. Disponível em: <http://link.springer.com/10.1007/s10113-011-0233x>. Acesso em: 30/8/2013.

PERZ, S. G.; QIU, Y.; XIA, Y.; et al. Trans-boundary infrastructure and land cover change: Highway paving and community-level deforestation in a tri-national frontier in the Amazon. Land Use Policy, v. 34, p. 27-41, 2013. Elsevier Ltd. Disponível em: $<$ http://linkinghub.elsevier.com/retrieve/pii/S026483771300029X>. Acesso em: 24/3/2014.

PIRILLO, E. La Evaluación de Impactos Ambientales ( EIA ) en espacios transfronterizos y la Evaluación Ambiental Estratégica ( EAE ). Realidad Economica, v. 257, p. 13, 2011. Disponível em: <http://www.iade.org.ar/modules/noticias/article.php? storyid=3455>. .

PNUMA; OTCA; CIUP. Perspectivas del medio ambiente en la amazonía, Geo amazonía. 2009.

PURNAMA, D. Review of transboundary environmental impact assessment: a case study from the Timor Gap. Impact Assessment and Project Appraisal, v. 22, n. 1, p. 17-35, 2004.

QUEIROZ, F. A. DE. MEIO AMBIENTE E COMÉRCIO NA AGENDA INTERNACIONAL : A QUESTÃO AMBIENTAL NAS NEGOCIAÇÕES DA OMC E DOS BLOCOS ECONOMICOS REGIONAIS. Ambiente \& Sociedade, v. VIII, n. 2, p. 1-23, 2005.

REDWOOD, J. The Environmental and Social Impacts of Major IDB-Financed Road Improvement Projects: The Interoceanica IIRSA Sur and IIRSA Norte Highways in Peru. 2012.

RHI-SAUSI, J. L.; COLETTI, R. Integración regional y cooperación transfronteriza en América Latina: experiencias y perspectivas. , p. 13, 2003.

RIBEIRO, R. Brasil, Argentina, Bolívia, Paraguai e Uruguai definem atribuições e devem apresentar projeto até 2015. InforMMA, 2012. Disponível em: <http://www.mma.gov.br/informma/item/8709-cuidando-da-bacia-do-prata>. .

RIBERA ARISMENDI, M. O. Megarepresas y energía: Megaproyectos del Madeira , Cachuela Esperanza, El Bala y Geotermia Laguna Colorada. Actualización 2009 - 2010. In: L. de D. del M. A.- LIDEMA (Ed.); Serie de estudios de caso sobre problematicas socio ambientales en Bolivia $\mathbf{N}^{\circ}$ 4. Espinoza, ed., p.184, 2010. La Paz - Bolivia: Programa de Investigación y Monitoreo Ambiental - LIDEMA. Disponível em: <file:///C:/Users/Tesis/Downloads/Contenido Represas WEB.pdf>. .

RIBERA, M. O. Primera aproximacion a un inventario de unidades ecoregionales amenazadas en Bolivia.Cartografía -SIG: Roberto Daza von Boeck. La Paz Bolivia, 2011. 
RITTNER, D.; BORGES, A. Bolívia reacende cobrança sobre usinas. Valor Economico, p. 6-8, 2014a. Disponível em: <http://www.valor.com.br/brasil/3455418/bolivia-reacende-cobranca-sobre-usinas>. .

RITTNER, D.; BORGES, A. Bolívia se queixa das enchentes do Madeira. Valor Economico, p. $1, \quad 2014 \mathrm{~b}$. Disponível em: <http://www.valor.com.br/search/apachesolr_search/Bol\%C3\%ADvia se queixa das enchentes do Madeira?solrsort=created desc\&filters=type\%3Avalor_international_conteudo -type\%3Awall_street_journal type\%3Avalor_ri* -channel\%3Ari>. .

ROCHA, E. C.; LORENSI, J.; PEREIRA, P. C. Avaliação de Impactos Ambientais nos Países do Mercosul. Ambiente \& Sociedade, v. VIII, n. 1414-753X, p. 147 - 160, 2005. Disponível em: <http://www.redalyc.org/articulo.oa?id=31780208>. .

RODRIGUEZ ARAQUE, A. Para la defenda de la vida, la paz y el desarrollo de la región UNASUR: Una estrategia integral. América Latina en Movimiento, p. 2 - 5, Sep. 2013. Quito - Ecuador.

ROJAS, G. A.; IZA, A. O.; CEDEÑO BONILLA, M. Evaluación de Impacto Ambiental Transfronteriza en Centroamérica. Lineamentos Generales. San José, Costa Rica: UICN-Mesoamérica, 2006.

SÁNCHEZ, L. E. Avaliacao de Impacto Ambiental: Conceitos e Métodos. Sao Paulo: Oficina de Textos, 2008.

SANT'ANNA, F. ANÁliSE DAS RELAÇÕES ENTRE BOLIVIA E BRASIL SOBRE OS RECURSOS HÍDRICOS COMPARTILHADOS NA BACIA AMAZÔNICA : DAS RELAÇÕES INTERNACIONAIS ÀS REGIÕES DE FRONTEIRA. VI Encontro Nacional da Anppas. Anais... p.1-17, 2012. Belém - PA - Brasil. Disponível em: <http://www.anppas.org.br/encontro6/anais/ARQUIVOS/GT9-611-1265-

20120628191856.pdf>. .

SCHRAGE, W.; BONVOISIN, N. Transboundary impact assessment: frameworks, experiences and challenges. Impact Assessment and Project Appraisal, v. 26, n. 4, p. 234-238, 2008. Disponível em: <http://www.tandfonline.com/doi/abs/10.3152/146155108X366004>. Acesso em: 31/8/2013.

SHANNON. Madeirarivermap. Disponível em: <http://commons.wikimedia.org/wiki/File:Madeirarivermap.jpg\#mediaviewer/File:Mad eirarivermap.jpg $>$. .

SILVA, E. L. DA; MUSZKAT MENEZES, E. Metodologia da Pesquisa e Elaboração de Dissertação. Florianópolis: UFSC, 2005.

SISNAMA. Programa Nacional de Capacitação de gestores ambientais: licenciamento ambiental. Brasilia - DF: Ministério do Meio Ambiente, 2009. 
TESLI, A.; HUSBY, S. EIA in a transboundary context: principles and challenges for a coordinated Nordic application of the Espoo convention. Environmental Impact Assessment Review, v. 19, n. 98, p. 57-84, 1999. Disponível em: $<$ http://scholar.google.com/scholar?hl=en\&btnG=Search\&q=intitle:EIA+IN+A+TRAN SBOUNDARY+CONTEXT+:+PRINCIPLES+AND+CHALLENGES+FOR+A+COO RDINATED+NORDIC+APPLICATION+OF+THE+ESPOO+CONVENTION\#0>. Acesso em: 8/9/2013.

TETLOW, M. F.; HANUSCH, M. Strategic environmental assessment: the state of the art. Impact Assessment and Project Appraisal, v. 30, n. 1, p. 15-24, 2012. Disponível em: <http://dx.doi.org/10.1080/14615517.2012.666400>. .

TSUTSUMI, R.; ROBINSON, K. Environmental Impact Assessment and the Framework Convention for the Protection of the Marine Environment of the Caspian Sea. In: K. Bastmeijer; T. Koivurova (Eds.); Theory and Practice of Transboundary Environmental Impact Assessment. p.391, 2008. Leiden: Martinus Nijhoff Publishers.

TUCCI, C. E. M. ANÁlise DOS ESTUDOS AMBIENTAIS DOS EMPREENDIMENTOS DO Sumário. , p. 1-19, 2007.

UNASUR. Declaración de Cochabamba Colocando la Piedra Fundamental para una Unión Sudamericana. Cochabamba - Bolivia, 2006.

UNASUR. IV REUNIÓN ORDINARIA DEL CONSEJO DE JEFAS Y JEFES DE $\begin{array}{lllllllll}\text { ESTADO } & Y & \text { DE GOBIERNO DE LA UNIÓN DE NACIONES }\end{array}$ SURAMERICANAS (UNASUR). Georgetown - Guyana, 2010.

UNASUR. DECLARACIÓN VI REUNIÓN ORDINARIA DEL CONSEJO DE JEFAS Y JEFES DE ESTADO Y DE GOBIERNO DE LA UNIÓN DE NACIONES SURAMERICANAS - UNASUR. Lima - Peru, 2012.

UNASUR; CEPAL. UNASUR Infraestructura para la integración regional. Santiago de Chile, 2011.

UNASUR; IIRSA; COSIPLAN. Reunión del Grupo Técnico Ejecutivo sobre la Metodología de Evaluación Ambiental y Social con Enfoque Estratégico ( EASE ). Santiago de Chile, 2013.

UNASUR; OLADE. UNASUR : Un espacio que consolida la integración energética. 2012.

UNECE. Review of Implementation of the convention on Environmental Impact Assessment in aTransboundary Context (2006-2009). ,2009. Disponível em: <http://www.unece.org/fileadmin/DAM/env/documents/2011/eia/ece.mp.eia.16.e.pdf>.

UNECE. First pilot project on post-project analysis under the UNECE Espoo Convention started with Belarus and Ukraine. UNECE, p. 1, 23. Apr. 2013. Geneva, Switzerland. Disponível em: <http://www.unece.org/index.php?id=32778>. . 
UNECE. Environmental Policy - Espoo Convention. Disponível em: $<$ http://www.unece.org/env/eia/about/amendment.html>. .

VENEZUELA. Constitución de la República Bolivariana de Venezuela. ,1999. Caracas - Venezuela: Gaceta Oficial de la Republica Bolivariana de Venezuela. Caracas, 30 de diciembre de 1999 No.36.860.

VENEZUELA. Decreto $N^{\circ} 2623$, de 23 de septiembre de 2003. Reglamento Orgánico del Ministerio del Ambiente y de los Recursos Naturales. ,2003. Caracas - Venezuela: Gaceta Oficial de la Republica Bolivariana de Venezuela. Caracas, 29 de septiembre de 2003 No.5664 Extraordinario.

VENEZUELA; ASAMBLEA NACIONAL. Ley Orgánica del Ambiente. ,2006. Caracas - Venezuela: Gaceta Oficial de la Republica Bolivariana de Venezuela. Caracas, 22 de diciembre de 2006 No.5833 Extraordinario. Disponível em: <http://www.minamb.gob.ve/files/Ley Organica del Ambiente/Ley-Organica-delAmbiente-2007.pdf $>$. .

WALSH; CONSECIONARIA IIRSA SUR. Informe final del Estudio de Impacto Socio Ambiental (EISA) del Corredor Vial Interoceánico del Sur Etapas II y III Tramo 2: Urcos - Inambari. Disponível em: $<$ https://www.mtc.gob.pe/portal/transportes/asuntos/proyectos/pvis-eisa_cvistramo_2.htm>. .

WWF; INSTITUT DE RECHERCHE POUR LE DÉVELOPPEMENT; IHH. Simposio Internacional "Evaluación de Impactos ambientales de grandes hidroeléctrica en regiones tropicales : El caso del río Madera.", 2009. La Paz - Bolivia. Disponível em: <http://www.cebem.org/cmsfiles/articulos/conclusiones_simposio_madera.pdf>. . 


\section{APÊNDICE A - QUESTIONÁRIOS APLICADOS.}

\section{PORTUGUÊS.}

Bom dia, meu nome é Angela Nayibe Moreno Torres, mestranda do programa de Ciências de Engenharia Ambiental, na Universidade de São Paulo, estou desenvolvendo minha pesquisa sobre a avaliação de impacto ambiental transfronteiriço nos países amazônicos, o objetivo da pesquisa é descrever as características institucionais e metodológicas da avaliação de impacto ambiental transfronteiriço em países da região Amazônica e avaliar sua efetividade.

Com o objetivo de continuar como o desenvolvimento de minha pesquisa gostaria de solicitar sua colaboração na resolução do seguinte questionário.

1. Tem conhecimento de políticas, métodos ou estratégias nacionais ou subregionais para o gerenciamento dos impactos ambientais transfronteiriços? Quais?

2. Qual é o procedimento a seguir quando se tem apresentado impactos ambientais transfronteiriços?

3. Lembra algum caso no qual tenha sido necessário o gerenciamento de este tipo de impactos? qual? Que procedimento seguiu?

\section{ESPANHOL.}

Buen dia, mi nombre es Angela Nayibe Moreno Torres, estúdio maestria en el programa de Ciencias de Ingenieria ambiental en la Universidad de São Paulo; actualmente desarrollo una investigación sobre evaluación de impacto ambiental transfronterizo en los paises amazonicos, su objetivo es describir las caracteristicas institucionales y metodologicas de la evaluación de impacto ambiental transfronteriza en paises de la region amazonica y evaluar su efectividad.

Con el objeto de continuar con el desarrollo de esta investigación, solicito su amable colaboración en el diligenciamiento del siguiente cuestionario. 
1. ¿Conoce politicas, metodos o estrategias nacionales o subregionales para el manejo de los impacto ambientales transfronterizos? ¿Cuáles?

2. ¿Cuál es el procedimiento a seguir cuando se presentan impactos ambientales transfronterizos, ya sean causados por su país o por un país vecino?

3. ¿Recuerda algun caso en el cual se presento este tipo de impacto ambiental?, ¿Cuál?, ¿Qué procedimiento se siguio?

\section{INGLÊS.}

Good morning, my name is Angela Nayibe Moreno Torres, im estuding master in the Environmental Engineering Sciences program, at the Sao Paulo university; currently developed a investigation on transboundary environmental impact assessment in Amazonian countries, its aim is to describe the institutional characteristics and methodological of transboundary environmental impact assessment on countries of the Amazon region and evaluate its effectiveness.

In order to continue development of this research, request your kind assistance in filling out the questionnaire.

1. Do you know of policies, methods or strategies, national or subregional for management of transboundary environmental impact? What?

2. What is the procedure to follow when there are transboundary environmental impacts, whether caused by their country or a neighboring country?

3. Do you remember any case in which present this type of environmental impact?, What?, What procedure is followed? 


\section{APÊNDICE B - LISTADO DOS ESCRITÓRIOS AOS QUE FOI ENVIADO.}

\section{Bolívia}

Ministério de Relações Exteriores:

Direção geral de limites, fronteiras e águas internacionais.

Ministério de Ambiente:

Unidade de programas em Meio Ambiente

Agencia para o desenvolvimento de Macrorregiões e zonas fronteiriçasADEMAF.

\section{Brasil}

Ministério de Meio Ambiente:

Gerencia de políticas para o licenciamento ambiental

Assessoria de assuntos internacionais

IBAMA:

Diretoria licenciamento ambiental

Sistema Eletrônico do Serviço de informação ao cidadão - e-SIC.

\section{Colômbia.}

Ministério de Ambiente e Desenvolvimento Sustentável:

Escritório de Assuntos Internacionais

Autoridade Nacional de Licenciamento Ambiental de Colômbia - ANLA

\section{Equador}

Ministério de Ambiente

Coordenador OTCA

Avaliação e controle para o eco - desenvolvimento regional amazônico ECORAE.

\section{Guiana}

Ministério de recursos naturais e ambiente 
Agencia de Proteção ambiental

\section{Peru}

Escritório de Cooperação e negociação internacional

Direção geral de políticas, normas e instrumentos de gestão ambiental

\section{Suriname}

Ministério de Meio Ambiente

Instituto nacional de ambiente e desenvolvimento

\section{Venezuela}

Escritório de Gestão e cooperação internacional Venezuela. 


\section{ANEXO A - NORMATIVAS REFERENTES AOS ASSUNTOS AMBIENTAIS NO ÂMBITO INTERNACIONAL NOS PAÍSES AMAZÔNICO.}

A continuação é descrito o marco institucional e normativo referentes aos assuntos ambientais, no âmbito internacional em cada um dos países amazônicos, assim como os objetivos e as políticas no campo ambiental dos órgãos sub - regionais atuantes na América do Sul.

\section{BOLÍVIA}

\section{Lei $N^{0} 1333$ de 1992}

Artigo $5^{\circ}$.

10. Compatibilização das políticas nacionais com as tendências da política internacional nos temas relacionados com o meio ambiente, tomando precauções quanto à soberania e os interesses nacionais.

Capítulo V. Dos assuntos do meio ambiente no contexto internacional.

Propõe o cumprimento dos tratados internacionais relacionados com o cuidado do ambiente (BOLIVIA, 1992).

\section{Regulamento geral de gestão Ambiental de 1995.}

Título 2 - Capítulo 2. Do Ministério de Desenvolvimento Sustentável e Meio Ambiente.

Artigo $7^{\circ}$.

D. Auxiliar o Ministério de Relações Exteriores na formulação da política ambiental internacional e definir as ferramentas e procedimentos para a cooperação externa.

M. emitir critérios técnicos quando se pressentem problemas transfronteiriços.

O. Promover assinatura, ratificação e implementação efetiva dos tratados, convênios, protocolos e outros instrumentos internacionais destinados à conservação do meio ambiente e dos recursos naturais.

\section{$\underline{\text { Regulamentacão de prevencão e controle Ambiental de } 1995 .}$}

Título I

Artigo $4^{\circ}$. 
O Ministério de Desenvolvimento Sustentável e Meio Ambiente (MDSMA), $\underline{\text { como autoridade nacional, terá competência em todos os projetos, obras ou atividades }}$ que tenham impactos internacionais transfronteiriços.

Título VIII.

Artigo 167.

$\underline{\text { Se um projeto, obra ou atividade se localiza nas zonas fronteiriças do país e }}$ ocasionam ou puderam ocasionar impactos ou riscos iminentes sobre o ambiente de um estado vizinho, assim como sobre os recursos naturais compartilhados com outros estados, o representante legal deve considerar essas circunstâncias no Estudo da AIA.

Quando existir convênio de reciprocidade entre o Ministério do Desenvolvimento Sustentável e Meio Ambiente, através do Ministério de Relações Exteriores e culto, informará os estados que podem ser afetados pela implementação, operação ou abandono de projetos, obras ou atividades, dos resultados dos estudos de AIA e das auditorias ambientais que sejam efetuadas com a finalidade de conhecer os impactos potenciais e efeitos atuais que os afetem ou possam afetar.

Toda transmissão de informação à respeito dos países vizinhos ou fronteiriços, deve guardar a confidencialidade correspondente.

Artigo 168.

Na ausência de tratados de cooperação sobre o controle de qualidade ambiental, deverá manter-se o princípio da comunidade para o aproveitamento de áreas florestais, protegidas, desenvolvimento e outros(BOLIVIA, 1995).

\section{Constituição Política da Bolívia de 2008.}

Artigo 264.

O Estado estabelecerá uma política permanente de desenvolvimento harmônico, integral, sustentável e estratégico das fronteiras, com a finalidade de melhorar as condições de vida de sua população, e, em especial, das nações e povos indígenas originários e campesinos fronteiriços.

II. É dever do Estado executar políticas de preservação e de controle dos recursos naturais nas áreas fronteiriças.

III. A regulação do regime de fronteiras será estabelecida pela lei.

Artigo 377.

Todo tratado internacional que subscreva o Estado sobre os recursos hídricos garantirá a soberania do país e priorizará o interesse dos Estados. 
O Estado resguardará de forma permanente as águas fronteiriças e transfronteiriças, para a conservação da riqueza hídrica que contribuirá para a integração dos povos.

\section{BRASIL}

\section{Lei Federal Nº 6.938 de 1981 - Política Nacional de Meio Ambiente} Artigo 10

A construção, instalação, ampliação e funcionamento de estabelecimentos e atividades utilizadores de recursos ambientais, considerados efetivo e potencialmente poluidores, bem como os capazes, sob qualquer forma, de causar degradação ambiental, dependerão de prévio licenciamento de órgão estadual competente, integrante do Sistema Nacional do Meio Ambiente - SISNAMA, e do Instituto Brasileiro do Meio Ambiente e Recursos Naturais Renováveis - IBAMA, em caráter supletivo, sem prejuízo de outras licenças exigíveis.

$4^{\circ}$ - Compete ao Instituto Brasileiro do Meio Ambiente e Recursos Naturais Renováveis - IBAMA, o licenciamento previsto no caput deste artigo, no caso de atividades e obras com significativo impacto ambiental, de âmbito nacional ou regional(BRASIL, 1981).

\section{Resolucão No 237 de 1997 do Conama}

Artigo $4^{\circ}$.

Compete ao Instituto Brasileiro do Meio Ambiente e dos Recursos Naturais Renováveis - IBAMA, órgão executor do SISNAMA, o licenciamento ambiental, a que se refere o artigo 10 da Lei $n^{\circ} 6.938$, de 31 de agosto de 1981, de empreendimentos e atividades com significativo impacto ambiental de âmbito nacional ou regional, a saber:

$\underline{\text { I - localizadas ou desenvolvidas conjuntamente no Brasil e em país limítrofe; }}$ no mar territorial; na plataforma continental; na zona econômica exclusiva; em terras indígenas ou em unidades de conservação do domínio da União.

III - cujos impactos ambientais diretos ultrapassem os limites territoriais do País ou de um ou mais Estados(BRASIL; CONAMA, 1997).

Decreto $N^{\circ} 6.101$ de 2007.

\section{ANEXO I}

Estrutura Regimental do Ministério do Meio Ambiente 
Capítulo III Das competências dos órgãos

Artigo $4^{\circ}$. À Secretaria-Executiva compete:

VII - supervisionar e coordenar os programas com financiamentos de organismos internacionais e estrangeiros, a implementação dos acordos internacionais e a execução dos convênios e projetos de cooperação técnica nacional e internacional;

Artigo $6^{\circ}$. Ao Departamento de Gestão Estratégica compete:

VII - coordenar, em articulação com as Secretarias do Ministério e as entidades vinculadas, o processo de elaboração e proposição de programas e projetos de cooperação técnica internacional;

VIII - apoiar a Assessoria de Assuntos Internacionais nas negociações com os organismos internacionais, entidades e governos estrangeiros, dos programas e projetos de cooperação técnica internacional;

Artigo 12. À Assessoria de Assuntos Internacionais compete:

I - assessorar o Ministro de Estado, as Secretarias do Ministério e as entidades vinculadas nos assuntos relacionados com cooperação internacional nas áreas de competência do

Ministério; II - coordenar, orientar e subsidiar a participação do Ministério em foros internacionais que tratam de questões relativas ao meio ambiente e aos recursos hídricos; III - atuar como interlocutor do Ministério e das suas entidades vinculadas junto ao $\begin{array}{llll}\text { Ministério das } & \text { Relações }\end{array}$ IV - articular e negociar com os organismos internacionais, entidades e governos estrangeiros o apoio aos programas e projetos relacionados à Política Nacional do Meio $\begin{array}{lllll}\text { Ambiente } & \text { e } & \text { dos } & \text { Recursos } & \text { Hricos; }\end{array}$ V - supervisionar e acompanhar a implementação dos acordos e convenções internacionais ratificados pelo Brasil na área de competência do Ministério; Artigo. 16. Ao Departamento de Licenciamento e Avaliação Ambiental compete:

IV - coordenar e executar as políticas públicas decorrentes dos acordos e convenções internacionais ratificadas pelo Brasil na sua área de atuação;

Art. 24. Ao Departamento de Recursos Hídricos compete:

VII - realizar estudos para a formulação de diretrizes de gerenciamento dos recursos hídricos fronteiriços e transfronteiriços (BRASIL, 2007).

\section{Lei complementar No 140 de 2011,}

Capítulo III das ações de cooperação

Artigo $7^{\circ}$. São ações administrativas da União: 
$\underline{\text { XIV - promover o licenciamento ambiental de empreendimentos e atividades: }}$

Localizados ou desenvolvidos conjuntamente no Brasil e em país
limítrofe;(BRASIL, 2011).

\section{COLÔMBIA}

\section{Decreto N$^{\circ} 2811$ de 1974.}

Parte II. Dos assuntos ambientais de âmbito ou influência internacionais.

Artigo 10. Para prevenir ou solucionar os problemas ambientais e regularizar a utilização de recursos naturais renováveis compartilhados com países limítrofes e sem dano aos tratados vigentes, o governo procurará complementar as estipulações existentes o negociar outros que forneçam.

a. O recíproco e permanente intercâmbio de informações necessárias para o planejamento do desenvolvimento e o uso ótimo de ditos recursos e elementos.

b. A reciprocidade prévia comunicação das alterações ou desequilíbrios ambientais que podem originar obras ou trabalhos projetados pelos governos ou os habitantes dos respectivos países, com antecipação suficiente para que ditos governos possam empreender as ações pertinentes quando considerem que seus direitos e interesses ambientais possam ser afetados.

c. A administração conjunta dos governos nos recursos naturais renováveis cuja exploração ou aproveitamento não possa ser fisicamente divisível entre os países interessados, ou que do ponto de vista técnico ou econômico não resulte conveniente dividir.

d. A adoção de medidas para que não cause prejuízos sensíveis aos outros países do uso puramente interno dos recursos naturais não renováveis ou outros elementos ambientais feitos na Colômbia ou em nações vizinhas.

Artigo 11. Os recursos naturais matéria das previsões a que se refere o artigo precedente são, entre outros, os seguintes: 
a. As bacias hidrográficas de rios que serve de limite ou que atravessam as fronteiras da Colômbia, incluídas as água superficiais e subterrâneas e os demais recursos naturais conexos.

b. Os bosques dos dois lados de uma fronteira

c. As espécies da fauna em que tenham interesse comum a Colômbia e os países vizinhos

d. As águas marítimas nacionais e os elementos que elas contem

e. A atmosfera, o quanto os atos já verificados ou os projetados em um país possam produzir efeitos nocivos no vizinho ou alterações climáticas prejudiciais.

f. Os depósitos geotérmicos que se estendam aos dois lados de uma fronteira.

Artigo 12. O governo procurará evitar ou proibirá a utilização de elementos ambientais e recursos naturais renováveis que possam produzir deterioração ambiental em países não vizinhos, em alto mar ou em seu leito, ou na atmosfera ou espaço aéreo, além da jurisdição territorial. O governo também procurará realizar gestões para obter que, em circunstâncias similares, outros países adotem atitude semelhante (COLOMBIA, 1974).

\section{Constituição Política de Colômbia 1991.}

Artigo. 80

... Cooperará com outras nações na proteção dos ecossistemas situados nas zonas fronteiriças.

Artigo 289.

Por mandato da lei, os departamentos e municípios localizados em zonas fronteiriças poderão adiantar diretamente com a entidade territorial limítrofe do país vizinho, de igual nível, programas de cooperação e integração, dirigidos a fomentar o desenvolvimento, a prestação de serviços públicos e a preservação do ambiente (COLOMBIA, 1991).

\section{Lei 99 de 1993}

Artigo $5^{\circ}$. Funções do Ministério de Meio Ambiente.

22. Participar com o Ministério de Relações Exteriores na formulação da política internacional em matéria ambiental e definir com este os instrumentos e procedimentos de cooperação na proteção dos ecossistemas das zonas fronteiriça; promover as relações com outros países em assuntos ambientais e a cooperação 
multilateral para a proteção dos recursos naturais e representar ao Governo Nacional na execução de tratados e convênios internacionais sobre o meio ambiente e recursos naturais renováveis.

Artigo 64. Funções dos Departamentos (Estados). Corresponde aos departamentos em matéria ambiental, além das funções que tenham sido delegadas pela lei ou das que sejam delegadas aos governadores pelo Ministério de Meio Ambiente ou pelas Corporações Autônomas Regionais, as seguintes atribuições especiais:

1. Desenvolver, com a assessoria ou a participação das Corporações Autônomas Regionais, programas de cooperação e integração com as entidades territoriais equivalentes e limítrofes do país vizinho, dirigidos a fomentar a preservação do meio ambiente comum e os recursos naturais renováveis binacionais (COLOMBIA; CONGRESO, 1993).

\section{Lei 191 de 1995}

Artigo $2^{\circ}$.

A ação do Estado em zonas de fronteira deverá ser orientada prioritariamente pela consecução dos seguintes objetivos:

...Preservação e aproveitamento sustentável dos recursos naturais e do ambiente.

Artigo 13. As inversões de qualquer caráter que sejam adiantadas nas zonas de fronteira deverão respeitar o meio ambiente, o interesse social, a diversidade étnica e o patrimônio cultural e arqueológico da nação. Quando se tratar de inversões em territórios indígenas e nas comunidades negras será elaborado um regulamento intercultural de manejo concertado com a população e o ministério de governo.

Artigo 46. As corporações autônomas regionais com jurisdição nas zonas de fronteira prestarão assistência técnica, administrativa e financeira aos departamentos e municípios fronteiriços que o requeiram em cumprimento de sua competência para adiantar programas de cooperação e integração dirigidos à preservação do ambiente e à proteção dos ecossistemas localizados em ditas zonas (COLOMBIA, 1995).

\section{Política de Gestão Ambiental Urbana de 2008.}

9.Delineamentos para a política de ordenamento ambiental do território

C. O objetivo específico 5 que pretende promover um maior equilíbrio interregional e internacional na distribuição de custos e benefícios ambientais, que implicam na concentração de oportunidades e riscos, têm as seguintes estratégias que apontam diretamente à gestão ambiental urbano regional: 
Promoção de mecanismos para conciliar a gestão e o ordenamento ambiental urbano em assentamentos fronteiriços, que por seus padrões hidrológicos, ecossistêmicos ou culturais, impliquem impactos em escala binacional ou internacional: o Ministério de Ambiente conjuntamente com o Ministério de Relações Exteriores promoverá a assinatura de acordos ou convênios de cooperação binacionais ou internacionais para a resolução de conflitos de uso e ocupação do território, investigação, difusão de informação e manejo de ecossistemas compartilhados com outras nações, que tendem à conservação e aproveitamento sustentável dos mesmos (COLOMBIA; MINISTERIO DE AMBIENTE, 2008).

\section{EQUADOR}

\section{Constituição da República do Equador}

Artigo 249. Os cantones (cidades) onde seus territórios se encontrem total ou parcialmente dentro de uma franja fronteiriça de quarenta quilômetros receberam atenção preferencial para afiançar uma cultura de paz e desenvolvimento socioeconômico, através de políticas integrais que cuidem da soberania, biodiversidade natural e intercultural. A lei regulamentará e garantirá a aplicação destes direitos.

\section{Livro I}

Da autoridade ambiental

Título I

Da missão, visão e objetivos do Ministério do Ambiente.

7.1.1.1.1 Gestão do patrimônio de áreas naturais do Estado.

17. Programa de implementação de estratégias regionais de biodiversidade (CDB, CAN, OTCA) relacionadas com as áreas protegidas.

7.1.1.1.2 Gestão de áreas protegidas municipais comunitárias

4.Estratégias de conservação e conectividade (áreas transfronteiriças, corredores biológicos, conservação, ecológicos, reservas da biosfera, regiões intangíveis e regiões de amortecimento) (ECUADOR).

\section{Lei $\mathbf{N}^{\circ} 37$ de 1999.}

Capítulo IV da participação das instituições do Estado

Artigo. 12. 
São obrigações das instituições do Estado do Sistema Descentralizado de Gestão Ambiental no exercício de suas atribuições e no âmbito de sua competência, as seguintes:

D. Coordenar com os organismos competentes para expedir e aplicar as normas técnicas necessárias para proteger o meio ambiente com sujeição às normas legais e regulamentárias vigentes e os convênios internacionais.

\section{GUIANA}

\section{Constituição da República Cooperativa de Guiana, 1980}

Capítulo II

37. O Estado apoia as aspirações legítimas de outros povos para a liberdade e a independência e estabelecerá relações com todos os Estados com base de igualdade soberana, com respeito mútuo a inviolabilidade das fronteiras, integridade territorial dos estados, com solução pacífica das controvérsias, a não intervenção nos assuntos internos, com respeito pelos direitos humanos, as liberdades fundamentais e a cooperação entre os Estados (GUYANA, 1980).

\section{Ato de Proteção Ambiental de 1996.}

Esta lei estabelece a Agência de Proteção Ambiental (EPA) como a instituição com o mandato de coordenar a gestão ambiental e prevê a gestão da conservação, proteção e melhora do meio ambiente, a prevenção ou controle da contaminação e a avaliação dos impactos sobre o meio ambiente das atividades do desenvolvimento econômico.

Parte II. Estabelecimento e funções da agência

4. As funções da agência são:

k. Estabelecer e coordenar as relações institucionais em nível local, regional e internacional.

\section{Parte IV Avaliação de Impacto Ambiental}

13. A decisão da agência para a expedição de uma permissão ambiental para um projeto estará sujeito às condições que sejam razoavelmente necessárias para proteger a saúde humana e o meio ambiente; cada licença ambiental conterá as seguintes condições implícitas: 
c. O diretor do projeto terá a obrigação de cumprir com qualquer direção da agência quando seu cumprimento seja necessário para a aplicação tratados ou leis internacionais relativas à proteção do meio ambiente assinados por Guiana e estratégias de desenvolvimento nacional (GUYANA, 1996).

\section{Estratégia nacional de desenvolvimento 1996.}

O Plano nacional de ação ambiental (NEAP,1994), com a finalidade de conservar e melhorar o meio ambiente o governo de Guiana se esforçará por:

... Promover o cumprimento da cooperação internacional em matéria ambiental $^{13}$.

\section{PERU}

\section{Decreto legislativo $\mathrm{N}^{\circ} 757$ de 1991. Aprovam lei marco para o crescimento da inversão privada.}

Artigo 13. De conformidade com o prescrito no último parágrafo do artigo 126 da constituição política, declara-se de necessidade nacional a inversão privada nacional e estrangeira, em atividades produtivas realizadas ou por realizar-se nas zonas de fronteira do país. Como consequência, as pessoas naturais e jurídicas estrangeiras poderão adquirir concessões e direitos sobre minas, terras, bosques, águas, combustíveis, fontes de energia e outros recursos que sejam necessários para o desenvolvimento de suas atividades produtivas dentro de cinquenta quilômetros das fronteiras do país, prévia autorização outorgada mediante resolução suprema referendada pelo ministro que exerça a presidência do Conselho de ministros e o ministro do setor correspondente. Dita resolução suprema poderá estabelecer as condições as quais se sujeita a aquisição ou exploração.

As autoridades setoriais competentes outorgaram as concessões e outras formas de autorização para a exploração de recursos naturais localizados dentro de cinquenta quilômetros das fronteiras do país em favor das pessoas naturais ou jurídicas estrangeiras que o solicitem, prévio cumprimento das disposições legais aplicáveis e depois de verificar que tenha sido expedida a resolução suprema a que se refere o parágrafo anterior.

\footnotetext{
${ }^{13} \mathrm{http} / / /$ www.guyana.org/NDS/chap18.htm
} 
Artigo 50. As autoridades setoriais competentes para conhecer sobre os assuntos relacionados com aplicação das disposições do Código do Meio Ambiente e os Recursos Naturais são os ministérios ou os organismos fiscalizadores, segundo seja o caso dos setores correspondentes às atividades que desenvolvam as empresas sem prejuízo das atribuições que correspondam aos governos regionais e locais conforme ao disposto na constituição política.

Artigo 51. A autoridade setorial competente comunicará ao conselho nacional do ambiente CONAM, sobre as atividades a serem desenvolvidas em seu setor, que por seu risco ambiental, puderam exceder os níveis ou parâmetros toleráveis de contaminação ou deterioração, obrigatoriamente deverão apresentar estudos de impacto ambiental prévios à sua execução e sobre os limites máximos permissíveis do impacto ambiental acumulado (PERU; MINISTERIO DEL AMBIENTE, 2010a).

\section{Constituição Política do Peru de 1993}

Artigo 44. São deveres primordiais do Estado...

Estabelecer e executar a política de fronteiras e promover a integração, particularmente latino americana, assim como o desenvolvimento e a coesão das zonas fronteiriças, em concordância com a política exterior.

Artigo 66. Os recursos naturais, renováveis e não renováveis são patrimônio da nação. O Estado é soberano em seu aproveitamento...(PERU; MINISTERIO DEL AMBIENTE, 2010a)

\section{Lei $\mathbf{N}^{\circ} 26821$ de 1997}

Lei orgânica para o aproveitamento sustentável dos recursos naturais.

Recursos naturais de caráter transfronteiriço.

Artigo 27. Os aspectos relacionados com a gestão dos recursos naturais transfronteiriços serão regidos pelos tratados sobre a matéria ou em seu defeito pela legislação especial (PERU; MINISTERIO DEL AMBIENTE, 2010a).

\section{Lei $\mathbf{N}^{\circ}$ 27446. Lei do sistema nacional de avaliação de impacto ambiental de 2001}

Artigo 61. Finalidade da AAE.

A avaliação ambiental estratégica - AAE constitui um processo sistemático, ativo e participativo que tem como finalidade internalizar a variável ambiental nas propostas de políticas, planos e programas de desenvolvimento que formulem as instituições do Estado, usando-a como uma ferramenta preventiva de gestão ambiental nos níveis de decisão que correspondam. 
Os resultados da AAE devem orientar a prevenção das implicâncias ambientais negativas significativas, assim como o conhecimento dos fluxos, tendências e padrões de desenvolvimento e a prevenção de possíveis conflitos socioambientais, de transcendência nacional ou internacional, que poderão gerar essas decisões.

Artigo 63. Conteúdo mínimo da AAE.

14. Outros conteúdos previstos pela normatividade internacional ou nas disposições de organismos internacionais que financiem, endossem ou respaldem a definição e aplicação das políticas, planos e programas sujeitas à AAE, segundo corresponda (PERU; MINISTERIO DEL AMBIENTE, 2010b).

\section{Acordo Nacional Política de Estado $\mathbf{N}^{\circ}$ 19. Desenvolvimento sustentável e gestão ambiental de 2002.}

...O Estado:

n. Cumprirá os tratados internacionais em matéria de gestão ambiental, assim como facilitará a participação e o apoio da cooperação internacional para recuperar e manter o equilíbrio ecológico (PERU; MINISTERIO DEL AMBIENTE, 2010b).

\section{Lei $N^{\circ} 28611$ de 2005}

\section{Artigo 12. - Da política exterior em matéria ambiental}

A promoção e defesa dos interesses do Estado, em harmonia com a Política Nacional Ambiental, os princípios estabelecidos na presente Lei e as demais normas sobre a matéria.

C. O respeito à soberania dos Estados sobre seus respectivos territórios para conservar, administrar, valorizar e aproveitar sustentavelmente seus próprios recursos naturais e o patrimônio cultural associado, assim como para definir seus níveis de proteção ambiental e as medidas mais apropriadas para assegurar a efetiva aplicação de sua legislação ambiental.

F. A realização do princípio de responsabilidades comuns, mas diferenciadas dos Estados e dos demais princípios contidos na Declaração da Rio-92 sobre o Meio Ambiente e o Desenvolvimento.

H. A cooperação internacional destinada ao manejo sustentável dos recursos naturais e à manter as condições dos ecossistemas e do ambiente em nível transfronteiriço, e além das zonas, onde, o Estado exerce soberania e jurisdição, de conformidade com o direito internacional. Dos recursos naturais transfronteiriços, se rege pelos tratados sobre a matéria ou em seu defeito pela legislação especial. 
O Estado promove a gestão integrada destes recursos e a realização de alianças estratégicas que conduzam o melhoramento das condições de sustentabilidade e o respeito das normas ambientais nacionais.

J. O estabelecimento, desenvolvimento e promoção do direito internacional ambiental.

\section{Artigo 87. - Dos recursos naturais transfronteiriços}

Os recursos naturais transfronteiriços regem-se pelos tratados sobre a matéria ou em seu defeito pela legislação especial. O Estado promove a gestão integrada destes recursos e a realização de alianças estratégicas que colaborem com o melhoramento das condições de sustentabilidade e o respeito das normas ambientais nacionais (PERU; MINISTERIO DEL AMBIENTE, 2010a).

\section{Decreto legislativo $N^{\circ} 1013$ de 2008.}

Lei de criação, organização e funções do Ministério do Ambiente.

Capítulo II. Funções.

6.2. Funções técnico-normativas.

c. Promover e subscrever convênios de colaboração interinstitucional em nível nacional e internacional de acordo com a lei.

Artigo 7. Funções específicas.

F. Dirigir o sistema nacional de avaliação de impacto ambiental e o sistema nacional de informação ambiental.

J. Implementar os acordos ambientais internacionais e presidir as respectivas comissões nacionais (PERU; MINISTERIO DEL AMBIENTE, 2010c).

\section{Decreto Supremo No 019 - 2009}

TÍTULO III Do processo de Avaliação Ambiental Estratégica das políticas, planos e programas públicos.

\section{Artigo 61. - Finalidade da AAE}

A Avaliação Ambiental Estratégica - AAE constitui um processo sistemático, ativo e participativo que tem como finalidade internalizar a variável ambiental nas propostas de políticas, planos e programas de desenvolvimento formulados pelas instituições do Estado, usá-los como uma ferramenta preventiva de gestão ambiental nos níveis de decisão correspondentes.

Os resultados da AAE devem ser orientados à prevenção das implicações ambientais negativas significativas, assim como, ao conhecimento dos fluxos, vieses e padrões de desenvolvimento e a prevenção de possíveis conflitos socioambientais, de 
transcendência nacional ou internacional, que poderiam gerar essas decisões (PERU; MINISTERIO DEL AMBIENTE, 2010b).

\section{Decreto supremo 012-2009-minam.}

Aprova a política nacional do ambiente

Fundamentos

9. Levando em conta as potencialidades e a situação ambiental do país, o Estado peruano tem ratificado tratados internacionais multilaterais, regionais e bilaterais que estabelecem importantes compromissos e oportunidades para a gestão ambiental e a competitividade do país. Mesmo assim, participa em diversos foros para a definição de políticas públicas internacionais de caráter ambiental e como parte de uma estratégia de integração, vem negociando uma série de tratados de livre comércio que devem contribuir a impulsionar o desenvolvimento econômico.

11. A alteração climática, a diminuição de florestas, a perda de diversidade biológica, a crescente escassez de água e a gestão limitada das substâncias químicas e materiais perigosos, são alguns dos problemas globais que se encontram baixo normas e tratados internacionais, cujo cumprimento nacional é necessário para impulsionar o Estado. Adicionalmente, é importante afiançar a interação comercial, homogeneizar os critérios e padrões para conquistar uma gestão ambiental sustentável e melhorar a competitividade comercial, aproveitando as oportunidades ambientais internacionais.

Eixo de política 4. Compromissos e oportunidades ambientais internacionais. Objetivos.

1. Assegurar que as posições nacionais em matéria ambiental apresentadas nos foros internacionais, acordos multilaterais e bilaterais, estejam articuladas e reflitam os interesses nacionais, contribuindo para orientar as decisões de ditos foros e acordos.

2. Conseguir que o cumprimento dos acordos internacionais subscritos e ratificados pelo Peru contribua eficientemente ao aproveitamento sustentável dos recursos naturais renováveis e o uso racional e responsável dos não renováveis.

3. Conseguir que nos processos de integração comercial, sejam homogeneizados os critérios e padrões ambientais com as políticas nacionais em matéria de comércio exterior, para melhorar a gestão ambiental, a competitividade, a proteção dos recursos naturais e a qualidade de vida das populações. 
Compromissos internacionais

Lineamentos de políticas.

a. Promover que os compromissos internacionais subscritos e que subscreva o Peru, sejam articulados ao acionar do Estado em seus três níveis de governo.

b. Fortalecer a capacidade negociadora do país para garantir que a participação no âmbito internacional tenha uma liderança reconhecida e resguarde os interesses nacionais em matéria de gestão ambiental e dos recursos naturais.

c. Impulsionar o acesso aos mecanismos de assistência técnica, transferência tecnológica e recursos financeiros para o fortalecimento das capacidades nacionais no marco de acordos e convênios internacionais em matéria ambiental.

d. Contribuir com o estabelecimento, desenvolvimento e promoção do direito internacional ambiental.

e. Consolidar os processos de negociação, cooperação e integração em nível internacional associados a posição geoestratégica e as vontades comparativas ambientais do país no âmbito global, em concordância com a política exterior do país e do comércio exterior

10. Desenvolvimento sustentável da Amazônia

Lineamentos da política

j. Promover a implementação de políticas binacionais e regionais com os países amazônicos para a gestão integral dos recursos e dos assuntos transfronteiriços (PERU; MINISTERIO DEL AMBIENTE, 2010b).

\section{SURINAME}

\section{Constituição de Suriname de 1987 com reformas de 1992.}

Sessão 2. Território.

Artigo $2^{\circ}$.O Estado não poderá alienar qualquer território ou direitos de soberania que exerce sobre o território.

Artigo $7^{\circ}$. 
A república do Suriname reconhece e respeita o direito das nações à livre determinação e a independência nacional sobre a base da igualdade, da soberania e do benefício mútuo.

A república do Suriname promove o desenvolvimento de ordem jurídico internacional e apoia a solução pacífica das controvérsias internacionais.

\section{VENEZUELA}

\section{Constituição da República Bolivariana de Venezuela, 1999.}

Artigo 15. O Estado tem a obrigação de estabelecer uma política integral nos espaços fronteiriços terrestres, insulares e marítimos, preservando a integralidade territorial, a soberania, a segurança, a defesa, a identidade nacional, a diversidade e o ambiente, de acordo com o desenvolvimento cultural, econômico, social e a integração. Atendendo a natureza própria de cada região fronteiriça através de alocações econômicas especiais, uma lei orgânica de fronteiras determinará as obrigações e objetivos desta responsabilidade.

Capítulo IX. Dos Direitos Ambientais

Artigo 129.

Todas as atividades susceptíveis de gerar estragos aos ecossistemas devem ser previamente acompanhadas de estudos de impacto ambiental e sociocultural...

Nos contratos em que a República celebre com pessoas físicas ou jurídicas, nacionais ou estrangeiras, ou nas permissões que sejam outorgadas, que afetem os recursos naturais, se considerará incluída ainda se não estiver expressa, a obrigação de conservar o equilíbrio ecológico, de permitir o acesso à tecnologia, e a transferência da mesma nas condições mutuamente conveniadas e de restabelecer o ambiente ao seu estado natural se este resultasse alterado, nos termos que fixe a lei.

Secção Quinta: Das relações internacionais.

Artigo 153. A República promoverá e favorecerá a integração latino-americana e caribenha, com a finalidade de avançar para a criação de uma comunidade de nações, defendendo os interesses econômicos, sociais, culturais, políticos e ambientais da região. A República poderá subscrever tratados internacionais que conjuguem e coordenem esforços para promover o desenvolvimento comum de nossas nações, e que garanta o bem-estar dos povos e a segurança coletiva de seus habitantes. Para estes fins, 
a República poderá atribuir às organizações supranacionais, através de tratados, o exercício das competências necessárias para levar a cabo estes processos de integração.

Dentro das políticas de integração e união com a América Latina e o Caribe, a República privilegiará relações com a Ibero-América, procurando uma política comum em toda nossa América Latina. As normas que sejam adotadas no marco dos acordos de integração serão consideradas parte integrada do ordenamento legal vigente e de aplicação direta e preferente à legislação interna (VENEZUELA, 1999).

\section{Decreto $N^{\circ}$ 2.623 de 2003. Regulamento orgânico do Ministério de Ambiente.}

Artigo 16. Corresponde ao escritório de gestão e cooperação internacional: 1 . Coordenar e apoiar a atuação internacional do escritório do ministro(a), dos escritórios dos vice-ministros(as); das demais dependências do Ministério e de seus organismos adstritos. 2. Atuar como unidade de enlace do Ministério com os organismos públicos e privados, nacionais e internacionais, com as representações diplomáticas acreditadas no país e com as embaixadas venezuelanas, para assuntos relacionados com convênios de cooperação técnica.

1. Participar e contribuir na elaboração de convênios ambientais internacionais, regionais e bilaterais no contexto de desenvolvimento sustentável, em coordenação com as instâncias competentes.

2. Avaliar os lineamentos derivados das negociações ambientais no âmbito internacional com o objetivo de identificar os alcances destes processos nas políticas nacionais.

3. Identificar, promover e gerir as oportunidades de cooperação técnica e financeira (não reembolsável).

4. Identificar e difundir as modalidades de cooperação de organismos e agências internacionais.

5. Promover as capacidades técnicas do Ministério em apoio aos programas de cooperação sub-regional e regionais.

6. Fortalecer a capacidade institucional nacional para a formulação, execução, avaliação e prosseguimento de programas e projetos de cooperação internacional.

7. As demais atribuições que conferem as leis, regulamentos e resoluções. Artigo 20. Corresponde à direção geral de bacias hidrográficas:

1. Estabelecer e coordenar conjuntamente com o escritório de gestão e cooperação internacional, assim como com os organismos competentes, 
as estratégias e lineamentos de ação para o tratamento da problemática ambiental das bacias hidrográficas internacionais e/ou fronteiriças.

Artigo 25. Corresponde ao escritório nacional de diversidade biológica.

20. Atuar como autoridade científica dos convênios nacionais e internacionais em matéria de sua competência.

Artigo 26. Corresponde à direção geral de Bosques:

14. Promover, coordenar, supervisar e dar prosseguimento aos acordos, convênios e cooperações institucionais, nacionais e internacionais em matéria de bosques.

Artigo 28. Corresponde à Direção Geral de educação ambiental e participação comunitária:

10. Manter relações com instituições e organismos internacionais a fim de firmar acordos e convênios que contribuam ao fortalecimento do sistema de educação ambiental e participação comunitária.

Artigo 34. Corresponde ao escritório administrativo de permissões:

2. Atuar como autoridade administrativa dos convênios internacionais em matéria autorizadora (VENEZUELA, 2003).

\section{Lei orgânica do ambiente, 2006}

Artigo $7^{\circ}$. A política ambiental deverá se fundamentar nos princípios estabelecidos na Constituição da República Bolivariana de Venezuela, na presente lei, e das outras leis que a desenvolvam e conforme os compromissos internacionais contraídos validamente pela República da Venezuela (VENEZUELA; ASAMBLEA NACIONAL, 2006). 
ANEXO B - RESPOSTAS AOS QUESTIONÁRIOS. 


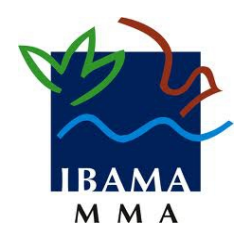

Instituto Brasileiro do Meio Ambiente e dos Recursos Naturais Renováveis

Auditória Interna do Ibama

Coordenação de Ouvidoria

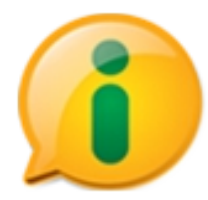

e-SIC

Sistema Eletrônico do Serviço de Informação ao Cidadão

\section{RESPOSTA DO PEDIDO DE INFORMAÇÃO}

\begin{tabular}{|l|l|l|}
\hline \multicolumn{1}{|c|}{ Número SISLIV: } & $07186 / 2013$ \\
\hline (X) Pedido de Informação & ( ) Recurso $1^{\text {a }}$ Instância & ( ) Recurso de $3^{\text {a }}$ Instância \\
\hline Referente ao documento: & MEM 009849/2013 SIC/IBAMA \\
\hline
\end{tabular}

\section{TEXTO DE RESPOSTA PARA O CIDADÃO/SOLICITANTE}

Sra. Angela Nayibe Moreno Torres,

em resposta à solicitação $07186 / 2013$ informamos que o representante oficial do Governo brasileiro nos assuntos relacionados aos impactos transfronteiriços é o Ministério das Relações Exteriores do Brasil - MRE. A Diretoria de Licenciamento envolve-se no âmbito técnico, a convite do Itamaraty, essencialmente analisando os dados e subsidiando o MRE nas negociações que envolvem impactos transfronteiriços e possíveis negociações de medidas mitigatórias.

A rigor, o Ibama é responsável pelo licenciamento de obras de impacto transfronteiriços, uma vez que a norma que regula a competência para o licenciamento ambiental é a Lei Complementar no 140/2011. Esta Lei estabeleceu que cabe a União (Ibama) promover o licenciamento ambiental de empreendimentos e atividades:

- Localizados ou desenvolvidos conjuntamente no Brasil e em país limítrofe;

- Localizados ou desenvolvidos no mar territorial, na plataforma continental ou na zona econômica exclusiva;

- Localizados ou desenvolvidos em terras indígenas;

- Localizados ou desenvolvidos em unidades de conservação instituídas pela União, exceto em Áreas de Proteção Ambiental (APA);

- Localizados ou desenvolvidos em 2 (dois) ou mais Estados;

- De caráter militar, excetuando-se do licenciamento ambiental, nos termos de ato do Poder Executivo, aqueles previstos no preparo e emprego das Forças Armadas, conforme disposto na Lei Complementar no 97, de 9 de junho de 1999;

- Destinados a pesquisar, lavrar, produzir, beneficiar, transportar, armazenar e dispor material radioativo, em qualquer estágio, ou que utilizem energia nuclear em qualquer de suas formas e aplicações, mediante parecer da Comissão Nacional de Energia Nuclear (Cnen); ou

- Que atendam tipologia estabelecida por ato do Poder Executivo, a partir de proposição da Comissão Tripartite Nacional, assegurada a participação de um membro do Conselho Nacional do Meio Ambiente (Conama), e considerados os critérios de porte, potencial poluidor e natureza da atividade ou empreendimento.

Destarte, via de regra, os empreendimentos transfronteiriços são submetidos ao rito ordinário de licenciamento, podendo haver reuniões técnicas convocadas pelos Ministérios das Relações Exteriores de ambos os países. A maioria dos casos concretos de empreendimentos 


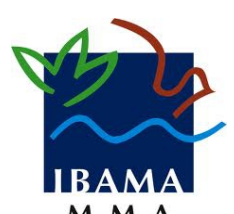

M M A

Instituto Brasileiro do Meio Ambiente e dos Recursos Naturais Renováveis

Auditória Interna do Ibama

Coordenação de Ouvidoria

transfronteiriços são pontes binacionais que, usualmente, não tem impactos ambientais significativos, uma vez que encontram-se em áreas já antropizadas e povoadas.

Em se tratando de processos licenciados pelo Ibama, pode-se consultar a documentação, incluindo licenças, diretamente via internet utilizando o navegador Mozilla Firefox. A grande parte dos documentos são de domínio público e está disponível on line.

Para informações frequentes, indicamos o link perguntas e respostas em licenciamento ambiental federal: http://www.ibama.gov.br/perguntas-frequentes/licenciamento-ambiental

Em nosso website a legislação federal está detalhada. Para legislações específicas, recomendamos que seja procurado o órgão estadual ou municipal de meio ambiente.

Atenciosamente,

SIC - Serviço de Informação ao Cidadão do Ibama

SCEN - Setor de Clubes Esportivos Norte - Trecho 02 Ed. Sede do Ibama Bloco: I CEP: 70.818-900 -

Brasília -DF -sic@ibama.gov.br 


\section{PROSPERIDAD
PARA TODOS}

MinAmbiente

Ministeño de Ambient'

¿Conoce políticas, métodos o estrategias nacionales o subregionales para el manejo de los impactos ambientales transfronterizos? ¿Cuáles?

Con la Declaración de Estocolmo en el año 1972, aprobada durante la Conferencia de las Naciones Unidas sobre Medio Ambiente Humano, por primera vez se introdujo en la agenda internacional el tema ambiental, limitando el modelo tradicional de crecimiento socio-económico y del uso de los recursos naturales.

Con base en dicho antecedente internacional, el Congreso Colombiano, atendiendo las recomendaciones derivadas de la Convención de Estocolmo, promulgó la ley 23 de 1973, concediendo facultades extraordinarias al Presidente de la Republica para expedir el Código de Recursos Naturales y Protección al Medio Ambiente; en este sentido, se profirió el Decreto-Ley 2811 de 1974, señalando, entre otras cosas, que el ambiente es patrimonio común, que el Estado y los particulares deben participar en su preservación y que el manejo de los recursos naturales es un asunto de utilidad pública e interés social ${ }^{1}$.

En 1991, el tema ambiental constituyó, sin lugar a dudas, una seria preocupación para la Asamblea Nacional Constituyente, pues ninguna Constitución moderna puede sustraer de su normatividad el manejo de un problema vital, no sólo para la comunidad nacional, sino para toda la humanidad; por ello, se ha afirmado con toda razón, que el ambiente es un patrimonio común de la humanidad y que su protección asegura la supervivencia de las generaciones presentes y futuras.

Como testimonio de lo anterior y afirmación de su voluntad por establecer los mecanismos para preservar un ambiente sano, en la Asamblea Nacional Constituyente se expresó lo siguiente:

"La protección al medio ambiente es uno de los fines del Estado Moderno, por lo tanto toda la estructura de este debe estar iluminada por este fin, y debe tender a su realización".

"Las crisis ambiental es, por igual, crisis de la civilización y replantea la manera de entender las relaciones entre los hombres. Las injusticias sociales se traducen en desajustes ambientales y éstos a su vez reproducen las condiciones de miseria" 7 (Sentencia T-254/93, M.P. Antonio Barrera Carbonell)".

Es así como, mediante la promulgación de nuestra Constitución Política en el año de 1991, el tema ambiental adquirió un rango constitucional al imponérsele al Estado la obligación de proteger las riquezas naturales y culturales de la nación, la diversidad e integridad del medio ambiente, los deberes de planificar el manejo y aprovechamiento de los recursos naturales y el de controlar los factores de deterioro ambiental

\footnotetext{
${ }^{1}$ En ejercicio de demanda de inconstitucionalidad, se solicitó la declaratoria de inexequibilidad de los artículos 19 y 20 de ley 23 de 1973 y de la totalidad del Decreto-ley 2811 de 1974, la cual fue resuelta por la Corte Constitucional en Sentencia C-126-1998 Magistrado Ponente. Alejandro Martinez Caballero
} 


\section{PROSPERIDAD
PARA TODOS}

MinAmbiente

con el objetivo primordial de garantizar el desarrollo sostenible, lo cual era compatible con el CNRNR y sus normas reglamentarias, así mismo la Honorable Corte en la Sentencia 411 del 17 de junio de 1999, de la Sala Cuarta de Revisión de la Honorable Corte Constitucional, con ponencia del Magistrado Alejandro Martínez Caballero, indicó:

"Para esta Sala de Revisión, la protección al ambiente no es un "amor platónico hacia la madre naturaleza", sino la respuesta a un problema que de seguirse agravando al ritmo presente, acabaría planteando una auténtica cuestión de vida o muerte: la contaminación de los ríos y mares, la progresiva desaparición de la fauna y la flora, la conversión en irrespirable de la atmósfera de muchas grandes ciudades por la polución, la desaparición de la capa de ozono, el efecto invernadero, el ruido, la deforestación, el aumento de la erosión, el uso de productos químicos, los desechos industriales, la lluvia ácida, los melones nucleares, el empobrecimiento de los bancos genéticos del planeta, etc., son cuestiones tan vitales que merecen una decisión firme y unánime de la población mundial. Al fin y al cabo el patrimonio natural de un país, al igual que ocurre con el histórico - artístico, pertenece a las personas que en él viven, pero también a las generaciones venideras, puesto que estamos en la obligación y el desafío de entregar el legado que hemos recibido en condiciones óptimas a nuestros descendientes(...)

Así, de acuerdo con lo establecido en el artículo $8^{\circ}$ de la Constitución Política de Colombia es obligación, a cargo del Estado colombiano y de los particulares, proteger las riquezas culturales y naturales de la Nación, con lo que claramente se relacionan principios de prevención frente a posibles afectaciones ambientales.

Igualmente, artículo 79 y 80 de la citada norma, indica que son deberes constitucionales del Estado, entre otros, proteger la diversidad e integridad del ambiente; conservar las áreas de especial importancia ecológica; planificar el manejo y aprovechamiento de los recursos naturales para garantizar su conservación y restauración, prevenir y controlar los factores de deterioro ambiental, imponer las sanciones y exigir la reparación de los daños causados.

Posteriormente, se celebraría la Conferencia de Rio de Janeiro de 1992, cuyo propósito fue el de responder a las inquietudes formuladas en el Informe Brundtland, y establecer los principios, estrategias y acciones que hagan compatible el desarrollo económico con la equidad social y la preservación de la base natural en que se sustenta, como un compromiso inaplazable de las presentes generaciones con la comunidad global y con los futuros habitantes del planeta dentro de los principios relacionados con la prevención de impactos ambientales trasfronterizos tenemos los siguientes:

- Principio 2. De conformidad con la Carta de las Naciones Unidas y los principios del derecho internacional, los Estados tienen el derecho soberano de aprovechar sus propios recursos según sus propias políticas ambientales y de desarrollo, y la responsabilidad de velar por que las 


\section{PROSPERIDAD
PARA TODOS}

MinAmbiente

actividades realizadas dentro de su jurisdicción o bajo su control no causen daños al medio ambiente de otros Estados o de zonas que estén fuera de los límites de la jurisdicción nacional.

- Principio 17. Deberá emprenderse una evaluación del impacto ambiental, en calidad de instrumento nacional, respecto de cualquier actividad propuesta que probablemente haya de producir un impacto negativo considerable en el medio ambiente y que esté sujeta a la decisión de una autoridad nacional competente.

- Principio 18. Los Estados deberán notificar inmediatamente a otros Estados de los desastres naturales u otras situaciones de emergencia que puedan producir efectos nocivos súbitos en el medio ambiente de esos Estados. La comunidad internacional deber hacer todo lo posible por ayudar a los Estados que resulten afectados.

- Principio 19. Los Estados deberán proporcionar la información pertinente, y notificar previamente y en forma oportuna, a los Estados que posiblemente resulten afectados por actividades que puedan tener considerables efectos ambientales transfronterizos adversos, y deberán celebrar consultas con esos Estados en una fecha temprana y de buena fe.

Es pertinente aclarar que la aplicación de los principios 18 y 19 antes mencionados está supeditada a los procedimientos que en marco de las relaciones bilaterales con otros países se establezcan, ello ante la inexistencia de un procedimiento específico para el efecto.

Posteriormente, con la expedición de la Ley 99 de 1993, se crea el Ministerio de Ambiente y Desarrollo Sostenible, reordena el Sector Público encargado de la gestión y conservación del medio ambiente y los recursos naturales renovables y organiza el Sistema Nacional Ambiental -SINA.

En la precitada ley, se adoptarían los principios generales ambientales contenidos en la Declaración de Río de Janeiro de junio de 1992 sobre Medio Ambiente y Desarrollo Sostenible, entre ellos, la evaluación de impacto ambiental, en la que indicó que los interesados en la ejecución de proyectos, obras 0 actividades, que generen un impacto ambiental significativo al medio ambiente deberán elaborar un ESTUDIO DE IMPACTO AMBIENTAL -EIA el cual será el instrumento básico para la toma de decisiones por parte de la autoridad ambiental al pronunciarse sobre la concesión de la LICENCIA AMBIENTAL y la responsabilidad de velar por que las actividades realizadas dentro de su jurisdicción o bajo su control no causen daños al medio ambiente de otros Estados o de zonas que estén fuera de los límites de la jurisdicción nacional.

A través del título VIII de la Ley 99 , se regula el licenciamiento ambiental del país como instrumento de manejo y control ambiental, con lo cual se sujeta a todos los beneficiarios de licencia ambiental al cumplimiento de las obligaciones, términos y condiciones que ella establezca en relación con la 


\section{PROSPERIDAD
PARA TODOS}

MinAmbiente

prevención, mitigación, corrección o compensación de los efectos ambientales negativos que pueda causar un proyecto, obra o actividad autorizado?2.

La adecuación de la institución legal de la licencia ambiental con la Constitución Política de Colombia, con base en la línea jurisprudencial de la Corte Constitucional, ha referido que la licencia ambiental: (i) es una autorización que otorga el Estado para la ejecución de obras o la realización de proyectos o actividades que puedan ocasionar un deterioro grave al ambiente o a los recursos naturales o introducir una alteración significativa al paisaje (Ley 99/93 art. 49); (ii) tiene como propósitos prevenir, mitigar, manejar, corregir y compensar los efectos ambientales que produzcan tales actividades; (iii) es de carácter obligatoria y previa, por lo que debe ser obtenida antes de la ejecución o realización de dichas obras, actividades o proyectos; (iv) opera como instrumento coordinador, planificador, preventivo, cautelar y de gestión, mediante el cual el Estado cumple diversos mandatos constitucionales, entre ellos proteger los recursos naturales y el medio ambiente, conservar áreas de especial importancia ecológica, prevenir y controlar el deterioro ambiental y realizar la función ecológica de la propiedad; ( $v$ ) es el resultado de un proceso administrativo reglado y complejo que permite la participación ciudadana, la cual puede cualificarse con la aplicación del derecho a la consulta previa si en la zona de influencia de la obra, actividad o proyecto existen asentamientos indígenas o afrocolombianos; (vi) tiene simultáneamente un carácter técnico y otro participativo, en donde se evalúan varios aspectos relacionados con los estudios de impacto ambiental $y$, en ocasiones, con los diagnósticos ambientales de alternativas, en un escenario a su vez técnico científico y sensible a los intereses de las poblaciones afectadas (Ley 99/93 arts. 56 y ss); y, finalmente, (vii) se concreta en la expedición de un acto administrativo de carácter especial, el cual puede ser modificado unilateralmente por la administración e incluso revocado sin el consentimiento previo, expreso y escrito de su titular, cuando se advierta el incumplimiento de los términos que condicionan la autorización (Ley 99/93 art. 62). En estos casos funciona como garantía de intereses constitucionales protegidos por el principio de prevención y demás normas con carácter de orden público."3(Subraya fuera de texto original)

En ese orden de ideas, la licencia ambiental trasciende el ámbito instrumental y se constituye en un mecanismo de planificación para garantizar que dentro de la variable ambiental se incluya obligaciones tendientes a la prevención, restauración y recuperación ambiental tendientes a evitar e impedir la generación de daños ambientales transfronterizos.

2. ¿Cuál es el procedimiento a seguir cuando se presentan impactos ambientales transfronterizos, ya sean causados por su país o por un país vecino?

De acuerdo con lo expuesto anteriormente, la licencia ambiental como instrumento de manejo y control ambiental de un proyecto, obra o actividad que pueda generar impactos ambientales negativos al medio ambiente o modificaciones notorias al paisaje tiene como fin impedir, prevenir y evitar la generación de

\footnotetext{
${ }^{2}$ Si bien la institución de la licencia ambiental se creó a partir de la ley 99 de 1993, ya existía la llamada Declaración de Efecto Ambiental para proyectos, obras o actividades susceptibles de producir deterioro ambiental, consagrada en los artículos 27 a 29 del Decreto-Ley 2811 de 1974.

${ }^{3}$ Sentencia C-746 de 2012. M.P.: Luis Guillermo Guerrero Pérez.
} 


\section{PROSPERIDAD
PARA TODOS}

MinAmbiente

Ministero de Ambente

impactos ambientales en el país o en un país vecino, situaciones que son garantizadas por Colombia a través de las actividades de evaluación, vigilancia y control que realizan las autoridades ambientales respecto de dichas actividades.

Sin embargo, si se llega a producir una situación de impacto ambiental transfronterizo, paras su verificación, análisis y posterior resolución, se activan los canales diplomáticos, siendo las Cancillerías de los países acompañadas por sus equipos técnicos, las que tratan de establecer la veracidad de los hechos y las posibles soluciones.

3. ¿Recuerda algún caso en el cual se presentó este tipo de impacto ambiental? ¿Cuál? ¿Qué procedimiento se siguió?

A la fecha no se tiene conocimiento de un caso sobre impacto ambiental trasfronterizo causado por Colombia a otros países; sin embargo Ecuador entabló una demanda ante la Corte Internacional de la Haya en contra de Colombia presuntamente por afectaciones ambientales generadas en el marco del programa de erradicación de cultivos ilícitos mediante el herbicida glifosato, situación que se encuentra controvertida totalmente por nuestro país. 